\title{
ipen
}

INSTITUTO DE PESQUISAS ENERGÉTICAS E NUCLEARES

Autarquia associada à Universidade de São Paulo

ESTUDO E AVALIAÇÃO DA RADIOMETRIA NO TRATAMENTO

FOTOTERÁPICO DA HIPERBILIRRUBINEMIA NEONATAL

José Pucci Caly

Tese apresentada como parte dos requisitos para a obtenção do Grau de Doutor em Ciências na Área de Tecnologia Nuclear - Materiais

Orientador:

Dr. Gessé Eduardo Calvo Nogueira

SÃO PAULO

2009 
INSTITUTO DE PESQUISAS ENERGÉTICAS E NUCLEARES

Autarquia associada à Universidade de São Paulo

\section{ESTUDO E AVALIAÇÃO DA RADIOMETRIA NO TRATAMENTO FOTOTERÁPICO DA HIPERBILIRRUBINEMIA NEONATAL}

José Pucci Caly

Tese apresentada como parte dos requisitos para a obtenção do Grau de Doutor em Ciências na Área de Tecnologia Nuclear - Materiais

Orientador:

Dr. Gessé Eduardo Calvo Nogueira 


\section{DEDICATÓRIA}

Aos meus pais Laurinda e José Caly (in memoriam) por terem sempre mostrado o melhor caminho e a Ivone Olívia pelo carinho e dedicação. 


\section{AGRADECIMENTOS}

Agradeço ao meu orientador Prof. Dr. Gessé Eduardo Calvo Nogueira pelo apoio constante, pela dedicação profissional e pelo amigo impares.

Ao Instituto de Pesquisas Tecnológicas do Estado de São Paulo -IPT e ao Instituto de Pesquisas Energéticas e Nucleares- IPEN pela cessão das instalações laboratoriais e materiais disponibilizados durante a realização deste trabalho.

Agradeço a todos os colegas do Centro de Integridade de Equipamentos do IPTCINTEQ, pela colaboração e companheirismo que me dedicaram no decorrer do trabalho.

Ao técnico e amigo Márcio Tadeu Hipólito pelo auxilio permanente ao longo da realização deste trabalho.

Aos Físicos: Jane Cleide Goveia Moreno, Oswaldo Sanchez Junior e Antonio Francisco Gentil Ferreira Junior e ao Técnico Raul Leoni Filho pela inestimável colaboração ao longo do trabalho.

Ao Dr. Niklaus Ursus Wetter pelo apoio constante ao longo deste trabalho.

Aos colegas do IPEN pelo auxilio constante e pronta solução dos problemas.

Aos colegas da Universidade Presbiteriana Mackenzie pelo incentivo e apoio.

Ao amigo e Prof. Affonso Sérgio Fambrini da Universidade Presbiteriana Mackenzie pela ajuda na verificação das formulações matemáticas que me tiravam o sono.

Ao Sr. Henrique e Eng. Leandro da Gigante Recém-nascidos Ltda. pelo empréstimo dos equipamentos e informações necessários ao longo deste trabalho.

A Sra. Ilze Puglia e a Sra. Vera Lúcia Garcia da Seção de Pós-graduação do IPEN pelas orientações e profissionalismo permanentes, além da paciência, carinho e disposição constantes no atendimento de minhas necessidades. 
"Se o cavalo soubesse a força que tem, nós puxaríamos a carroça."

José Caly 


\title{
ESTUDO E AVALIAÇÃO DA RADIOMETRIA NO TRATAMENTO FOTOTERÁPICO DA HIPERBILIRRUBINEMIA NEONATAL
}

\author{
José Pucci Caly \\ RESUMO
}

A fototerapia é um procedimento estabelecido há mais de 50 anos no tratamento da icterícia em recém-nascidos. No entanto ainda não há um método padronizado de quantificação da dose fototerápica nos estudos clínicos publicados, dificultando a comparação de estudos prévios sobre a eficácia da fototerapia, bem como o estabelecimento de doses seguras e previsíveis. A dose fototerápica depende, dentre outros fatores, da irradiância média útil entregue pelas unidades fototerápicas. Mas não há procedimentos padronizados tanto na quantificação da irradiância útil ao tratamento, quanto na estimação da irradiância média útil em fontes fototerápicas. Por isso, têm sido relatadas grandes variações nas medições de uma mesma fonte usando os radiômetros disponíveis no mercado, como conseqüência da vasta diversidade de responsividades espectrais dos instrumentos.

Um objetivo deste trabalho foi adaptar e aplicar os princípios da radiometria ultravioleta de banda larga na quantificação da irradiância disponível em fontes fototerápicas, estabelecendo procedimentos que permitem comparar irradiâncias medidas em diversas fontes, usando radiômetros com diferentes responsividades espectrais. Outro objetivo foi caracterizar amostras de fontes comumente usadas atualmente, focando o problema da estimação da irradiância média útil em unidades de fototerapia, propondo um método de estimação da irradiância média útil em fontes com foco dirigido.

Os resultados experimentais obtidos nos permitem concluir que não somente é necessário padronizar a radiometria fototerápica, como também o método de estimação da irradiância média útil. 


\title{
STUDY AND EVALUATION OF RADIOMETRY IN PHOTOTHERAPEUTIC TREATMENT OF THE NEONATAL HIPERBILIRUBINEMIA
}

\author{
José Pucci Caly
}

\begin{abstract}
Phototherapy is a procedure established more than 50 years ago in the treatment of the newborn jaundice. However there is no a standard method to quantify the phototherapeutic dose in published clinical studies, hindering the comparison of previous studies on phototherapeutic effectiveness, as well as the establishment of safe and predictable doses. The phototherapeutic dose depends, among other factors, on the effective mean irradiance produced by the phototherapeutic unit. There are no standard procedures, however, neither to quantify the effective irradiance, nor to estimate the mean effective irradiance. As a consequence, large measurement variations in a same phototherapeutic unit are observed using different commercially available radiometers, as a consequence of the vast diversity of spectral responsivities of the instruments.

An objective of this work was to adapt and to apply the bases of the wideband ultraviolet radiometry to quantify the available irradiance from phototherapeutic units, establishing procedures that allow us to compare measured irradiances from different sources, using radiometers presenting different spectral responsivities. Another objective was to characterize samples of phototherapeutic units commonly used, focusing the problem of the estimation of the effective mean irradiance from phototherapeutic units, proposing a method to estimate of the effective irradiance from focused sources.

The experimental results allow us to conclude that it is not only necessary to standardize the phototherapeutic radiometry, but also the method of estimation of the effective mean irradiance.
\end{abstract}




\section{SUMÁRIO}

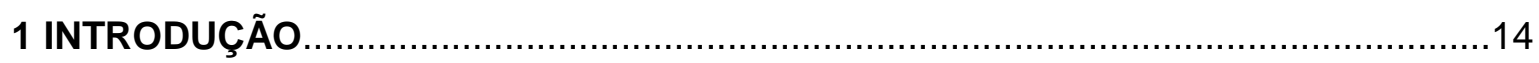

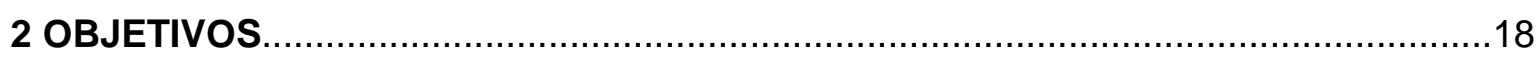

3 FOTOTERAPIA NA ICTERÍCIA NEONATAL ................................................ 19

3.1 Fototerapia e radiometria na icterícia neonatal....................................................19

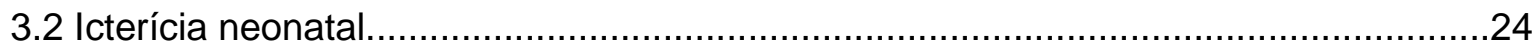

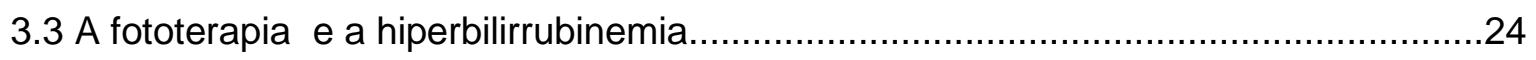

3.4 Os processos de redução da bilirrubina............................................................25

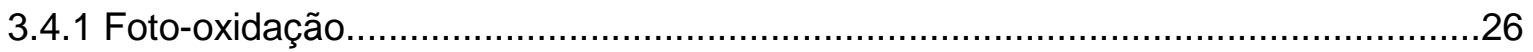

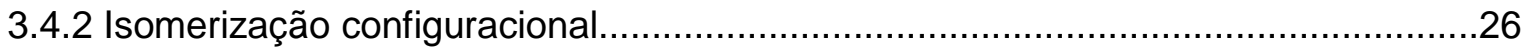

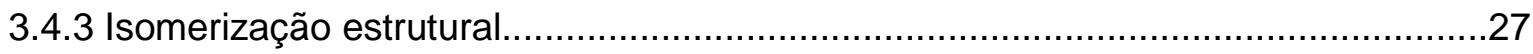

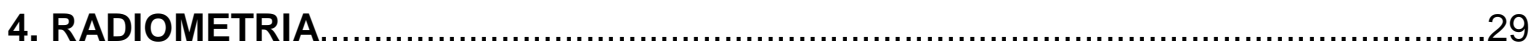

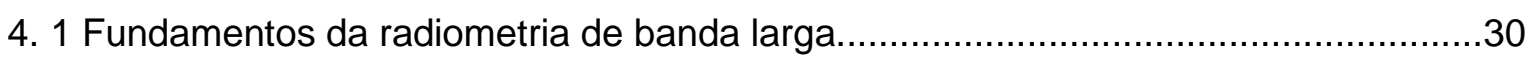

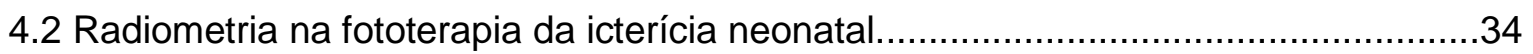

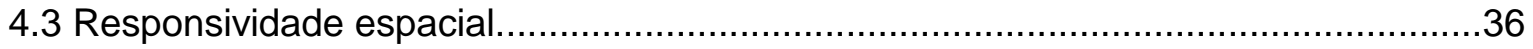

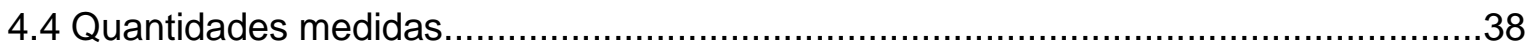

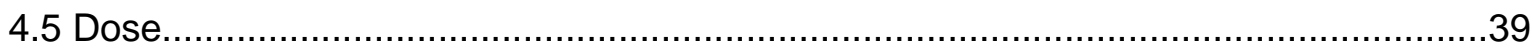

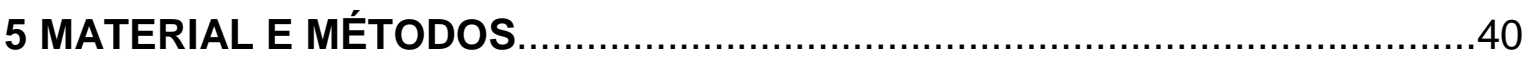

5.1 Unidades de fototerapia e radiômetros comerciais......................................40

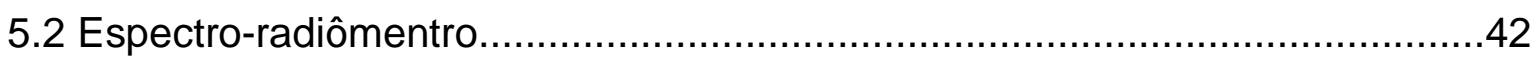

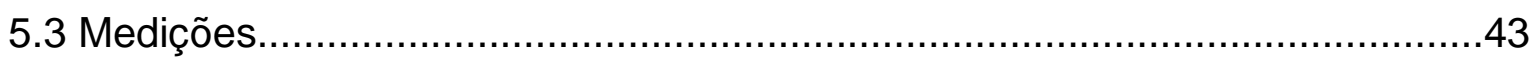

5.3.1 Irradiância eficaz........................................................................ 43

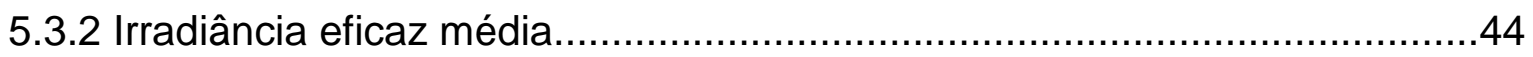

5.4 Caracterização dos radiômetros.......................................................... 49

5.4.1 Resposta espacial do fotodetector.................................................49

5.4.2 Resposta espectral do fotodetector.............................................50

5.5.1 Determinação das características dos radiômetros...................................51 
5.5.2 Quantificação dos erros espaciais .51

6 RESULTADOS. .54

6.1.1 Responsividades espaciais dos radiômetros. .55

6.2 Irradiâncias espectrais das fontes. .56

6.3 Responsividade espectral do detector. .59

6.4 Irradiância eficaz média das fontes. 61

6.5 Estimativas dos erros espaciais. .63

7 DISCUSSÕES 66

7.1 Medição da irradiância eficaz. .66

7.1.1 Quantidades e unidades. 66

7.1.2 Calibração. .68

7.1.3 Transferência de calibração. 76

7.2 Irradiância eficaz média. .79

7.3 Conseqüências dos erros nas medições. .82

8 CONCLUSÕES. .84

\section{ANEXOS}

ANEXO A - Tabelas com os Valores das irradiâncias eficazes. .85

ANEXO B - Tabelas com os valores das irradiâncias. .97 


\section{LISTA DE TABELAS}

Tabela 6.1 - Iradiâncias eficazes calculadas em unidades arbitrárias das fontes F1 $\mathrm{F} 2, \mathrm{H} 1$ e $\mathrm{H} 2$.. .59

Tabela 6.2 - Valores das características dos radiômetros R1 e R2 e dos espectros de ação DIN e G para as fontes ensaiadas F1,F2, H1 e H2. 60

Tabela 6.3 - Valores das irradiâncias eficazes médias das fontes F1, F2, H1 e

$\mathrm{H} 2$. 61

Tabela 6.4 - Valores das irradiâncias espectrais eficazes médias das fontes F1, $\mathrm{F} 2$, $\mathrm{H} 1$ e $\mathrm{H} 2$. 63

Tabela 7.1 - Valores de irradiâncias eficazes extraídos de $\operatorname{Tan}(1982) \ldots \ldots \ldots \ldots \ldots . . . . .83$

Tabela A1 - Valores de irradiâncias eficazes de ER medindo F1 ............................85

Tabela A2 - Valores de irradiâncias eficazes espectrais de R1 medindo F1 .........86

Tabela A3 - Valores de irradiâncias eficazes espectrais de R2 medindo F1 .........87

Tabela A4 - Valores de irradiâncias eficazes de ER medindo F2 .........................88

Tabela A5 - Valores de irradiâncias eficazes espectrais de R1 medindo F2.........89

Tabela A6 - Valores de irradiâncias eficazes espectrais de R2 medindo F2 ........90

Tabela A7 - Valores de irradiâncias eficazes de ER medindo H1........................91

Tabela A8 - Valores de irradiâncias espectrais eficazes de R1 medindo H1 .......92

Tabela A9 - Valores de irradiâncias espectrais eficazes de R2 medindo H1........93

Tabela A10 - Valores de irradiâncias eficazes de ER medindo H2......................94

Tabela A11 - Valores de irradiâncias espectrais eficazes de R1 medindo H2......95

Tabela A12 - Valores de irradiâncias espectrais eficazes de R2 medindo H2......95 
Tabela B1 - Valores de irradiâncias, Valores de irradiâncias espectrais eficazes, Valores de irradiâncias eficazes corrigidas e o erro efetuadas com os radiômetros $\mathrm{R} 1 \mathrm{e} \mathrm{R} 2$ para a fonte $\mathrm{F} 1$

Tabela B2 - Valores de irradiâncias, Valores de irradiâncias espectrais eficazes, Valores de irradiâncias eficazes corrigidas e o erro efetuadas com os radiômetros R1e R2 para a fonte F2 98

Tabela B3 - Valores de irradiâncias, Valores de irradiâncias espectrais eficazes, Valores de irradiâncias eficazes corrigidas e o erro efetuadas com os radiômetros $\mathrm{R} 1 \mathrm{e} \mathrm{R} 2$ para a fonte $\mathrm{H} 1$ 99

Tabela B4 - Valores de irradiâncias eficazes, Valores de irradiâncias espectrais eficazes, Valores de irradiâncias eficazes corrigidas e o erro efetuadas com os radiômetros R1e $\mathrm{R} 2$ para a fonte $\mathrm{H} 2$. 100 


\section{LISTA DE FIGURAS}

Figura 3.1 - Espectro de absorção da bilirrubina e seus foto-isômeros.................25

Figura 3.2 - Foto-isômerização configuracional da bilirrubina..............................27

Figura 3.3 - Ciclização intramolecular da bilirrubina na presença da luz para a formação da lumirrubina..............................................28

Figura 5.1 - Unidades de fototerapia fluorescentes..........................................

Figura 5.2 - Distribuição dos pontos de medição para as fontes fluorescentes....45

Figura 5.3 - Projeção elíptica do feixe de luz as unidades halógenas .................46

Figura 5.4 - Disposição de pontos proposta por Fachini (2001)...........................47

Figura 5.5 - Distribuição dos pontos de medição para as fontes halógenas.

Figura 5.6 - Esquema de montagem para o levantamento da responsividade espacial.

Figura 5.7 - Curvas de responsividade espectral de irradiância dos detectores R1,R2, espectro de ação DIN e de uma Gaussiana $\mathrm{G}(460,26) \mathrm{nm}$. .50

Figura 5.8 - Curva Espetros relativos de F2 nos pontos (1) e (10) de sua superfície efetiva.

Figura 6.1 - Diagrama polar das responsividades espaciais dos detectores

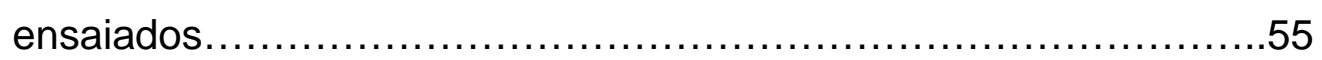

Figura 6.2 - Erro co-seno dos detetores ER, R1, R2 ensaiados.........................56

Figura 6.3 -Irradiância espectral da fonte F1 ..............................................57

Figura 6.4 -Irradiância espectral da fonte F2 ……........................................57

Figura 6.5 -Irradiância espectral da fonte $\mathrm{H} 1$.............................................

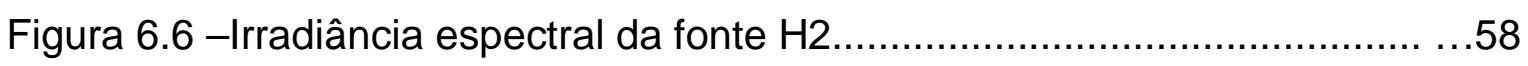

Figura 6.7 - Gráfico tridimensional dos erros encontrados quando R2 é calibrado

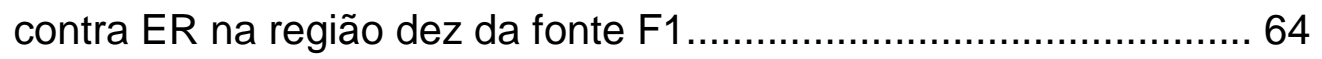

Figura 6.8 - Quadros (A) e Quadro (B) erros encontrados quando R2 é ajustado

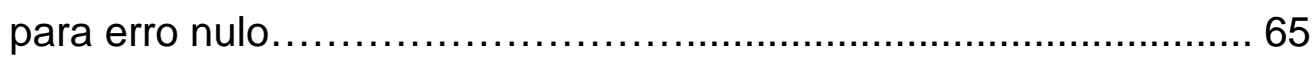




\section{Lista de símbolos}
$A_{n}$ - Área do setor elíptico $n$
$C_{a}$ - Características do detector com curva aproximada
$C_{p 1}-$ Características do detector com fonte padrão
$E(\lambda)$ - Irradiância espectral
$E_{c}-$ erro de co-seno
$E_{\text {ef- Irradiância eficaz }}$
$E_{n}$ - Irradiância medida no setor elíptico $n$
$f-$ fator de ajuste do medidor para fontes diferentes
I - Intensidade da radiação incidente
$I_{c}(\theta, \phi)-$ Sinal do detector
$I_{D}-$ Sinal do detector
$P_{n}-$ Potência no setor elíptico $n$
Q - Quantidade de irradiância aproximada
$Q_{p 1}$ - Irradiância eficaz da fonte 1 com a curva de ação aproximada $S_{a}$
$r$ - Constante de correção
$R$ - fator de calibração
$S_{p}(\lambda)$ - Curva de ação padrão
$S_{a}(\lambda)$ - Curva de ação aproximada
$S_{\max }-$ Valor máximo da responsividade 


\section{INTRODUÇÃO}

Entre $60 \%$ e $70 \%$ dos recém-nascidos de termo e a quase totalidade de prematuros apresentam quadro de icterícia neonatal clínica detectável nos primeiros dias de vida (Vreman et al., 2004). Com a adoção do tratamento fototerápico, constatou-se a redução em aproximadamente $80 \%$ das transfusões sangüíneas em recém-nascidos, este procedimento impõe um menor risco ao paciente e mostra-se como a alternativa mais viável de tratamento (De Carvalho et al., 1999).

A utilização de unidades fototerápicas no tratamento de hiperbilirrubinemia foi introduzida em 1958 nos Estados Unidos (Maisels, 1981). No Brasil este método de tratamento foi introduzido no início da década de 60 (Ferreira et al., 1960).

Embora a fototerapia seja um procedimento comum no tratamento de hiperbilirrubinemia há mais de 50 anos, é reconhecido que ainda é necessário conhecer mais a fotobiologia da bilirrubina, as características dos equipamentos de fototerapia, a eficácia e segurança da fototerapia. Também precisam ser melhorados os instrumentos de medição da radiação óptica entregue pelos equipamentos de fototerapia, objetivando melhorar as práticas clínicas, tornandoas mais previsíveis e seguras (Vreman et al., 2004).

Os equipamentos destinados à fototerapia usam fontes artificiais de luz, emitindo numa faixa espectral adequada ao tratamento. Desde o princípio da fototerapia era conhecido que a luz na faixa azul do espectro é terapeuticamente efetiva (Modi e Keay, 1983). Atualmente acredita-se que a faixa espectral em que o processo de foto-alteração da bilirrubina ocorre com eficácia é aproximadamente entre $400 \mathrm{~nm}$ e $520 \mathrm{~nm}$, que é a faixa aproximada de absorção da bilirrubina (Vreman et al., 2004).

Avanços na fototerapia ocorreram na década de setenta do século passado com os primeiros estudos sobre dose-resposta, buscando estabelecer uma relação entre a energia luminosa recebida pelo neonato e o decréscimo da 
bilirrubina. Mas nos primeiros estudos a radiação luminosa emitida por fontes fototerápicas era medida usando fotômetros, adequados para medir a luz segundo a resposta da visão humana, mas inadequados para medir a porção azul do espectro onde a foto-alteração da bilirrubina ocorre (apud Modi e Keay, 1983). Não encontrando relação entre as quantidades fotométricas e respostas terapêuticas, a quantidade radiométrica irradiância foi adotada (Tan, 1982). Os primeiros radiômetros usados eram dotados de filtros ópticos que permitiam a passagem da luz azul. Alguns tentavam ajustar o filtro ao espectro de ação da bilirrubina (Modi e Keay, 1983). Mas os radiômetros apresentavam respostas máximas (picos) e larguras diferentes. Talvez por esta razão, numa tentativa de compensar tais variações, a irradiância medida é até hoje dividida pela largura do filtro. A "nova" quantidade é denominada "irradiância espectral". Assim a irradiância tem sido freqüentemente expressa em $\left(\mu \mathrm{W} / \mathrm{cm}^{2} \cdot \mathrm{nm}\right)$, apresentando a mesma dimensão de irradiância espectral. Segundo Maisels (2001), "irradiância espectral" expressa a irradiância em uma "certa" faixa de comprimentos de onda. Na prática, "irradiância espectral" em fototerapia é a razão entre a irradiância e a largura do filtro usado. Mas, em função da diversidade de respostas espectrais, cada radiômetro assim construído mede uma quantidade diferente de uma mesma fonte, dividindo a irradiância medida ou não pela largura do filtro óptico usado (Modi e Keay, 1983).

Tem sido verificado que em adição à irradiância, a pigmentação e espessura da pele, o tempo de exposição e a área da superfície corpórea do neonato exposta à radiação óptica são fatores determinantes (entre outros) no sucesso ou insucesso do tratamento. Contudo a "irradiância espectral" tem sido usada como medida de "dose" em um tratamento (Vreman et al., 2004). Embora este fato seja reconhecido, segundo Maisels, (2001) não existe um método padronizado na literatura para quantificar a irradiância útil no tratamento fototerápico: diversos pesquisadores têm usado vários instrumentos com diversas respostas espectrais e tem expressado seus resultados em diferentes unidades. Como um resultado, é difícil comparar estudos publicados sobre a eficácia da fototerapia.

Sob o ponto de vista clínico, segundo dados fornecidos por Tan (1982), erros de medição na ordem de $50 \%$ no valor da irradiância podem significar a não 
efetividade do tratamento em $41,7 \%$ dos casos, significando um prolongamento no tempo do tratamento (desperdício de tempo e de recursos dos sistemas de saúde, público ou não), e até necessidade de transfusão.

Existem várias formas de se medir e quantificar a radiação óptica: um espectro-radiômetro, por exemplo, pode ser usado para medir o espectro da radiação óptica. Conhecendo o espectro da radiação óptica, é possível quantificar a irradiância numa faixa do espectro. Alternativamente um radiômetro também pode ser usado para medir a irradiância numa faixa do espectro.

Os radiômetros são instrumentos que têm potencial para a medição da radiação em condições clínicas e laboratoriais. O baixo custo, a fácil operacionalidade e sua construção simples que geralmente é baseada no emprego de fotodiodos de silício acoplados a circuitos eletrônicos de compensação, medem a irradiância em uma faixa espectral selecionada usando filtros passa-banda, instalados na entrada do sensor óptico (Klein 1972). Tais filtros deveriam ser desenhados para resultarem responsividades que reproduzam o espectro de ação fototerápica da bilirrubina (Modi e Keay, 1983). Uma função que descreve a eficácia do processo de foto-alteração, em função do comprimento de onda é denominado espectro de ação. Mas, ainda não há um espectro de ação largamente aceito no tratamento da icterícia neonatal (NBR IEC 60.601-2-50:2003).

Atualmente existem vários radiômetros comerciais específicos para a medição da irradiância no tratamento da hiperbilirrubinemia, mas têm sido relatadas diferenças superiores a $100 \%$ nos valores das irradiâncias de uma mesma fonte de luz, medidas com radiômetros diferentes (Vreman et al., 2004). Segundo Vreman et al., (2004), tais diferenças decorrem do fato de que os radiômetros comerciais geralmente são calibrados para fontes específicas. No entanto é comum em instalações fototerápicas o uso de um único radiômetro no monitoramento de fontes fototerápicas diferentes. Tal procedimento resulta doses imprecisas, significando tratamentos ineficazes (quando a irradiância medida é maior que a disponível), prolongando o tratamento, ou tratamentos superiores aos necessários (a irradiância medida é menor que a disponível), ou ainda trocas desnecessárias de lâmpadas das fontes. Segundo os autores, um medidor 
padrão e portável, capaz de medir qualquer fonte, seria uma solução desejada, mas ainda não disponível.

Recentemente a American Academy of Pediatrics (AAP) publicou
diretrizes destinadas ao gerenciamento do tratamento clínico da hiperbilirrubinemia em neonatos com 35 ou mais semanas de gestação (AAP, 2004). As diretrizes incluem a fototerapia como tratamento e prescreve procedimentos, mas apontam i) a ausência de um método padronizado de quantificação da dose fototerápica nos estudos clínicos publicados, dificultando a comparação de estudos prévios sobre a eficácia da fototerapia e ii) a ausência de um procedimento padronizado de quantificação da irradiância média num tratamento, pois a radiação óptica entregue por unidades fototerápicas geralmente varia largamente na superfície do neonato.

No decorrer deste trabalho foi verificado que os fundamentos da radiometria ultravioleta de banda larga podem ser adaptados e aplicados à radiometria fototerápica, respondendo às necessidades acima apontadas. Ainda, os fundamentos permitem modelar, estudar e controlar erros nas medições das irradiâncias decorrentes de desajustes do espectro de ação, que também são tópicos ainda inexplorados na literatura. 


\section{OBJETIVOS}

O objetivo principal deste trabalho foi adaptar e aplicar os princípios da radiometria ultravioleta de banda larga na quantificação da irradiância disponível em fontes fototerápicas.

Outro objetivo deste trabalho foi caracterizar amostras de fontes com lâmpadas fluorescentes e halógenas e radiômetros empregados no tratamento da hiperbilirrubinemia neonatal de equipamentos de fabricação nacional freqüentemente usados nas unidades de terapia intensivas neonatais nos hospitais do Brasil. 


\section{FOTOTERAPIA NA ICTERICIA NEONATAL}

Este capítulo apresenta brevemente a fototerapia e a radiometria na icterícia neonatal e os processos de redução da bilirrubina. Inicialmente será abordada uma revisão bibliográfica da fototerapia desde o seu surgimento até os dias de hoje. Na seqüência são sucintamente apresentados a icterícia neonatal, o tratamento fototerápico da icterícia neonatal e os processos fotoquímicos de redução da bilirrubina.

\subsection{Fototerapia e radiometria na icterícia neonatal}

As unidades de fototerapia são empregadas no tratamento da hiperbilirrubinemia neonatal desde 1958, quando se observou que a luz, sobretudo a faixa azul do espectro visível, proporciona uma diminuição significativa na concentração plasmática da bilirrubina (Cremer et al., 1958).

Lucey et al. (1968) desenvolveram um estudo comprovando que o uso profilático da fototerapia reduz os níveis da serum-bilirrubina do paciente prematuro, quando usada de maneira contínua, por períodos de 12 a 144 horas de vida.

Antes de 1972 a medição da luz e a efetividade do tratamento fototerápico da hiperbilirrubinemia neonatal baseavam-se na grandeza fotométrica foot-candel (pé-candela), o que correspondia à medição da iluminância (Bonta e Warshaw, 1976).

Lucey (1972) chama a atenção dos pesquisadores para o estudo da eficácia do tratamento fototerápico quando baseado na medição da grandeza "fluxo radiante" (sic) expressa em unidades de $\mu \mathrm{W} / \mathrm{cm}^{2}$ (irradiância) como grandeza padrão da radiação óptica em substituição à grandeza até então comumente usada, o foot-candle. $\mathrm{O}$ autor também sugere a faixa espectral de eficácia do tratamento: entre $400 \mathrm{~nm}$ e $550 \mathrm{~nm}$.

Sisson et al. (1972) demonstraram que a queda dos níveis de serumbilirrubina é proporcional à intensidade da irradiância aplicada, mas não guarda relação de proporcionalidade com a grandeza de iluminância. Assim, a irradiância no intervalo espectral de $400 \mathrm{~nm}$ a $550 \mathrm{~nm}$, expressa em $\mu \mathrm{W} / \mathrm{cm}^{2}$, passou a ser a 
grandeza adotada internacionalmente no tratamento da hiberbilirrubinemia neonatal.

MacLeod e Stern (1972) desenvolveram um estudo considerando a distribuição da luz natural ambiente na enfermaria e sua influência no tratamento de icterícia de pacientes prematuros. O estudo mostra que a intensidade da radiação solar incidente, a posição em que o paciente se encontra na enfermaria e o período do dia, influenciam na redução dos níveis de bilirrubina. Com base neste estudo os autores sugerem que tais fatores devam ser levados em consideração ao se fazer o projeto arquitetônico da enfermaria pediátrica.

Sisson et al. (1972) compararam o efeito da concentração da serumbilirrubina em 72 pacientes com icterícia fisiológica, quando submetidos ao tratamento de fototerapia. Neste trabalho as unidades de fototerapia eram homogeneamente equipadas com três tipos diferentes de lâmpadas fluorescentes (luz do dia, azul padrão, azul especial de banda estreita). Os resultados mostraram que a luz azul especial de banda estreita, apesar de iluminar menos, foi a que mais forneceu energia na região azul do espectro visível, que é a faixa mais efetiva para o tratamento da hiperbilirrubinemia. Por outro lado, as lâmpadas luz do dia demonstraram a menor efetividade terapêutica.

Tan (1975) analisou os efeitos de dois sistemas de fototerapia (unidirecional, cuja irradiação é aplicada sobre o paciente e o bidirecional, cuja irradiação é aplicada por um conjunto de lâmpadas instalado sobre o paciente e outro instalado sob o mesmo e operam simultaneamente), apesar de um sistema trabalhar em uma direção e o outro em duas, os dois forneciam a mesma quantidade de energia para o tratamento. Os resultados mostraram que a eficiência do tratamento depende da dose aplicada ao paciente (irradiância $x$ área corpórea x tempo de exposição) e não apenas da área corpórea irradiada.

Bonta e Warshaw (1976) determinaram em um experimento com 42 pacientes divididos em três grupos, que a menor irradiância eficaz para 0 tratamento da hiperbilirrubinemia é $4,0 \mu \mathrm{W} / \mathrm{cm}^{2} \mathrm{~nm}$, quando medido na faixa espectral de $400 \mathrm{~nm}$ a $500 \mathrm{~nm}$ empregando o instrumento IL 155 Color Radiometer (International Ligth Inc. - USA). 
Ballowitz et al. (1977) em busca de um espectro de ação da bilirrubina mais realista para avaliar a relação dose/reposta em fototerapia, executaram um trabalho no qual ratos (Gun rats) foram iluminados sob condições controladas por oito diferentes tipos de lâmpadas fluorescentes. Correlacionando as distribuições espectrais das lâmpadas com os decréscimos dos níveis da bilirrubina encontrados no experimento, foi calculado um espectro de ação. Assim foi possível desenvolver um instrumento para medir a radiação efetiva ministrada ao paciente. A relação dose/resposta no uso de fototerapia foi demonstrada por Mims et al. (1973) e por Bonta e Warshaw (1976) empregando equipamentos convencionais de fototerapia. Sisson et al. (1972) e Tan (1977) fizeram o mesmo estudo usando fontes especialmente construídas.

Tan (1982) estudou a resposta da bilirrubina à fototerapia usando lâmpadas com espectro de emissão próximo ao espectro de absorção da bilirrubina. A relação dose/resposta foi demonstrada, com o aumento da intensidade da fototerapia resultando em maior resposta. Entretanto a taxa de bilirrubina diminuiu progressivamente com o aumento da irradiância, até que um ponto de "saturação" foi encontrado e além do qual não havia declínio da bilirrubina para um dado aumento da irradiância. Estes efeitos de saturação da diminuição da bilirrubina ocorreram a partir de $1,6 \mathrm{~mW} / \mathrm{cm}^{2}$ para a faixa espectral de $425 \mathrm{~nm}$ a $475 \mathrm{~nm}$.

Segundo Enever et al. (1983), o comprimento de onda mais efetivo para a foto-isomerização da bilirrubina in vitro encontra-se na faixa espectral de $390 \mathrm{~nm}$ a $470 \mathrm{~nm}$. Os autores comentaram que a luz verde (530 nm) não é efetiva para a produção do foto-isômero, e é capaz de reverter à reação. Os resultados indicam que toda unidade de fototerapia clinicamente aplicada deveria incluir a faixa azul do espectro e sugere que a efetividade da fototerapia deve aumentar com a eliminação da luz verde.

Sbrana et al. (1987) estudaram a ação clínica das lâmpadas fluorescentes verdes no tratamento da hiperbilirrubinemia. No estudo, os comprimentos de onda inferiores a $500 \mathrm{~nm}$ foram devidamente filtrados. O trabalho foi realizado em um grupo de 23 pacientes com diferentes concentrações iniciais de bilirrubina. Os resultados obtidos foram comparados com outros anteriores, sob as mesmas condições experimentais (em um grupo exposto a 
radiação de lâmpadas verdes comerciais). Segundo os autores um decréscimo similar nas taxas de bilirrubina foi observado nos dois experimentos, o que confirma a eficácia clínica da luz verde em fototerapia e mostra, em particular, que o componente azul presente na emissão pode ser desprezado no processo de foto-alteração da bilirrubina.

Costarino et al. (1985), Babin et al. (1991) e Hansen (2000) estudaram a utilização de unidades de fototerapia de altas intensidades, cujos resultados demonstraram maior eficiência no tratamento em comparação com as fontes convencionais. Entretanto o emprego de alta intensidade depende das condições clinicas do paciente e não devem ser aplicados para todos os casos (Caldera, Sender, 1997).

Maisels (1996) comentando a relação dose/resposta em pacientes submetidos ao tratamento, alerta que valores publicados de irradiâncias espectrais usando diferentes radiômetros e diferentes sistemas de fototerapia não podem ser comparados, "uma vez que os detectores são projetados segundo a característica espectral da curva de ação da redução da bilirrubina, entretanto, não há uma curva padrão estabelecida".

Vreman (1998) desenvolveu um equipamento de fototerapia com LED de alta intensidade e estudou diferentes tipos de LED (azul, azul-verde, verde e branco) concluindo que as emissões na faixa azul foram as mais eficientes no tratamento.

De Carvalho et al. (1999) desenvolveram uma unidade de tratamento que usava sete lâmpadas brancas, do tipo luz do dia, posicionadas imediatamente abaixo da base de uma cuba de plexiglass transparente, que faz as funções de berço, onde o paciente repousa enquanto está em tratamento. Foi efetuado um estudo de caso envolvendo vinte e um pacientes com a finalidade de comparar esta unidade de tratamento a duas outras unidades convencionais nas quais um conjunto de lâmpadas posicionadas perpendicularmente a $35 \mathrm{~cm}$ sobre o berço irradiou o neonato. As unidades convencionais foram equipadas com dois conjuntos de lâmpadas diferentes, uma com as lâmpadas do tipo azul especial, e a outra com lâmpadas brancas do tipo luz do dia. A nova unidade de tratamento emitia irradiância de $19 \mu \mathrm{W} / \mathrm{cm}^{2} \mathrm{~nm}$. Na unidade convencional equipada de lâmpadas com do tipo azul especial a irradiância foi de $21 \mu \mathrm{W} / \mathrm{cm}^{2} \mathrm{~nm}$ e na 
unidade convencional dotada de lâmpadas brancas do tipo luz do dia a irradiância para o tratamento foi de $4 \mu \mathrm{W} / \mathrm{cm}^{2} \mathrm{~nm}$. Os resultados mostraram que tanto a fototerapia convencional com lâmpadas do tipo azul especial, como a nova configuração com lâmpadas brancas, apresentaram a mesma eficiência no tratamento. Os autores concluíram que a nova configuração é eficiente quando as lâmpadas são posicionadas próximas ao paciente.

Fachini (2001) propõe padronização de um método para a avaliação dos equipamentos de fototerapia a partir de modelos de distribuição da irradiância espectral, medida com radiômetros comerciais. Na prática o valor da irradiância máxima disponível em uma fonte de irradiação depende da fonte de luz e de restrições como a distância mínima segura entre a fonte e o neonato. Contudo, valores de irradiâncias máximas disponíveis nas fontes comerciais comumente usadas no Brasil são pouco conhecidas e os dados disponíveis foram obtidos usando radiômetros cujas características metrológicas são desconhecidas.

Vieira et al.. (2004) efetuaram uma avaliação prática da aplicação da fototerapia em clínicas pediátricas do Rio de Janeiro onde médicos e profissionais da enfermagem foram entrevistados quanto aos procedimentos empregados na aplicação do tratamento, com base nas recomendações do guia da American Academy of Pediatrics (AAP, 2004). A pesquisa mostra que não existe consenso entre os profissionais que atuam na área quanto aos procedimentos adotados, sobretudo quanto à medição da irradiância aplicada, do tempo de vida útil das lâmpadas e da distância entre as fontes e os radiômetros. Na pesquisa todos os hospitais avaliados tinham equipamentos com fontes halógenas, mas $30 \%$ também tinham fontes fluorescentes e apenas um (dentre os 17 hospitais) empregou equipamento de fototerapia com fibras ópticas. $O$ trabalho não cita fontes a LED.

Vreman (2004) ressaltou a necessidade do desenvolvimento dos espectro-radiômetros e radiômetros para uso clínicos no sentido de tornar previsíveis os resultados dos tratamentos de fototerapia.

Ebbesen et al. (2007) estudou o emprego de lâmpadas fluorescentes com o pico de emissão em $490 \mathrm{~nm}$ e faixa de emissão de $65 \mathrm{~nm}$, e concluiram que a radiação nesta faixa (turquesa) é até $25 \%$ mais eficiente na fotoisomerização da bilirrubina do que as fontes azuis com pico em $452 \mathrm{~nm}$ e faixa de 
emissão de $55 \mathrm{~nm}$. A maior eficiência do tratamento é associada à maior penetração da radiação na pele, a menor formação do isômero Z,E-bilirrubina e a maior produção do isômero E,Z-bilirrubina e lumirrubina.

\subsection{Icterícia neonatal}

A icterícia neonatal resulta do aumento da bilirrubina, formada pela quebra da hemoglobina no corpo. A bilirrubina é removida pela placenta quando no útero, mas a partir do nascimento, o fígado do recém-nascido deve assumir a função de processamento. Entretanto, o fígado do pré-maturo pode demorar alguns dias para ser efetivo e, enquanto isso, a bilirrubina aumenta nos tecidos, resultando a hiperbilirrubinemia neonatal. O principal risco associado aos elevados níveis de bilirrubina do neonato é o dano no cérebro. A albumina do sangue armazena o pigmento, mas pode tornar-se saturada e a bilirrubina causar danos irreversíveis no cérebro, ou até óbito. Por isso é desejável reduzir os níveis de bilirrubina a valores significativamente abaixo daqueles apontados como limites críticos, tão rápido quanto possível (Dicken et al., 2000).

\subsection{A fototerapia e a hiperbilirrubinemia}

A foto-sensibilidade da bilirrubina começou a ser estudada durante uma série de ensaios, in vitro, da serum-bilirrubina de pacientes ictéricos na tentativa de aplicá-la terapeuticamente. A bilirrubina, um tipo de pigmento predominante em recém-nascidos ictéricos, é aproximadamente duas a três vezes mais fotosensível que a bilirrubina conjugada. Esta descoberta enfatizou a necessidade de procedimentos laboratoriais de rotina para a avaliação da bilirrubina de neonatos que apresentam icterícia (Cremer et al., 1958). O que motivou tal estudo foi a observação antecipada de uma enfermeira, que notou que havia uma diminuição do tom amarelado nos pacientes expostos à luz do sol. Tais resultados foram confirmados qualitativamente em exames laboratoriais seqüenciais para a determinação da serum-bilirrubina. Assim, um grupo de neonatos foi exposto, sem roupas, à luz solar direta, com proteção nos olhos, durante intervalos intermitentes de 15 minutos. A intermitência da exposição tinha a intenção de diminuir os riscos de aquecimento do paciente, assim como controlar a exposição do paciente a radiação ultravioleta. Verificou-se que as áreas do corpo que 
haviam ficado expostas à radiação solar apresentaram tons de amarelado atenuados. Paralelamente os exames laboratoriais demonstraram a queda dos níveis da serum-bilirrubina em 12 dos 13 pacientes avaliados. (Cremer et al.,. 1958). Com base nestes resultados, foi adotada uma fonte de luz artificial em substituição à luz natural. O equipamento era constituído de um refletor hemisférico em aço inoxidável com braço ajustável. Medindo 609,6 mm de comprimento (24 polegadas), com lâmpadas fluorescentes de $40 \mathrm{~W}$, com 50,4 mm (2 pol.) de diâmetro, dispostas ao longo da curvatura do refletor. Este arranjo fornecia luz de alta intensidade na faixa espectral de $420 \mathrm{~nm}$ a $480 \mathrm{~nm}$, sem, entretanto, a presença de componentes da radiação ultravioleta ou raios $X$ (Cremer et al., 1958).

\subsection{Os processos de redução da bilirrubina}

No que se refere ao processo de foto-redução da bilirrubina, quando esta absorve um fóton, uma das três reações químicas pode ocorrer: fotooxidação, isomerização configuracional ou a isomerização estrutural. A FIG. 3.1 mostra o espectro de absorção da bilirrubina e de seus foto-isômeros segundo Migliorini et al., 1988 (apud Ennever, 1990), na redução da bilirrubina. Estes processos serão comentados a seguir.

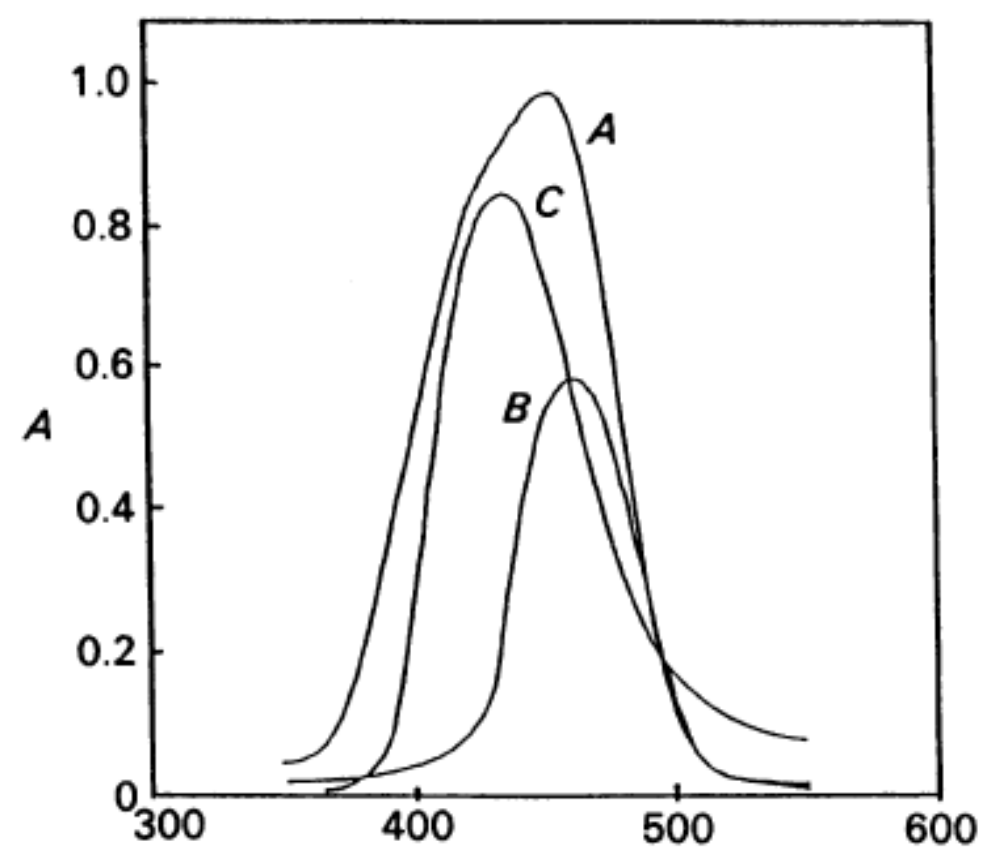

FIGURA 3.1- Espectro de Absorção da bilirrubina e seus foto-isômeros.

Espectro da bilirrubina Z-Z (A), bilirrubina Z-E (B) e lumirrubina (C). 


\subsubsection{Foto-oxidação}

A foto-oxidação forma produtos incolores e inicialmente, acreditava-se ser este o processo responsável pela eliminação da bilirrubina do paciente. Uma das importantes informações que conduziram ao desenvolvimento da fototerapia foi o desaparecimento gradual da bilirrubina de uma amostra exposta à luz solar. A clarificação é resultado da foto-oxidação da bilirrubina, que tem como resultado vários produtos incolores e solúveis em água (Ennever, 1990).

Desde o começo da adoção da fototerapia nos anos 50 até a década de 80 , acreditava-se que a fototerapia agia basicamente pelo processo de fotooxidação da bilirrubina. Ligthner et al. (1984), identificaram produtos da fotooxidação na urina de pacientes submetidos à fototerapia. Embora, a foto-oxidação da bilirrubina contribua para a diminuição da bilirrubina durante a fototerapia, trata-se de um processo lento, e vários estudos sugerem que este caminho tem uma contribuição menor para a eliminação da bilirrubina durante a fototerapia (Ennever 1990).

\subsubsection{Isomerização configuracional}

Isômeros são substancias que têm diferentes propriedades físicoquímicas, mas a mesma fórmula molecular. A isomerização configuracional ou geométrica ocorre com os componentes que têm dupla ligação. A bilirrubina possui simetricamente duas ligações substituídas, uma começando com o átomo de carbono $\mathrm{C} 4$ e a outra em $\mathrm{C} 15$. Por isso, existem quatro isômeros geométricos para a bilirrubina: 4Z15Z; 4Z15E; 4E15Z e 4E15E. Nos neonatos que recebem fototerapia, o isômero nativo estável 4Z15Z, (i.e., aquele produzido in vivo pela redução da hemoglobina) é convertido predominantemente em apenas um dos três isômeros, o isômero 4Z15E (FIG 3.2). Nesta reação, um dos anéis terminais passa por uma rotação de $180^{\circ}$ ao redor da dupla ligação C5. Quando isto ocorre o nitrogênio polar e os grupos de oxigênio são expostos, formando uma terminação da molécula polar e permitindo a excreção na bile sem a conjugação. A formação da bilirrubina $4 Z 15 E$ é espontânea e reversível no escuro, diferentemente da foto-oxidação ou formação da lumirrubina (Isomerização estrutural). Assim, a bilirrubina 4Z15, formada na pele e expelida pelo fígado é rapidamente convertida em bilirrubina não conjugada ordinária. Além disso, a 
conversão fotoquímica do isômero normal ZZ para um isômero menos estável 4Z15E é reversível pela luz visível e conduz a rápida formação de outro. (Ennever, 1990; Maisels et.al., 1994)
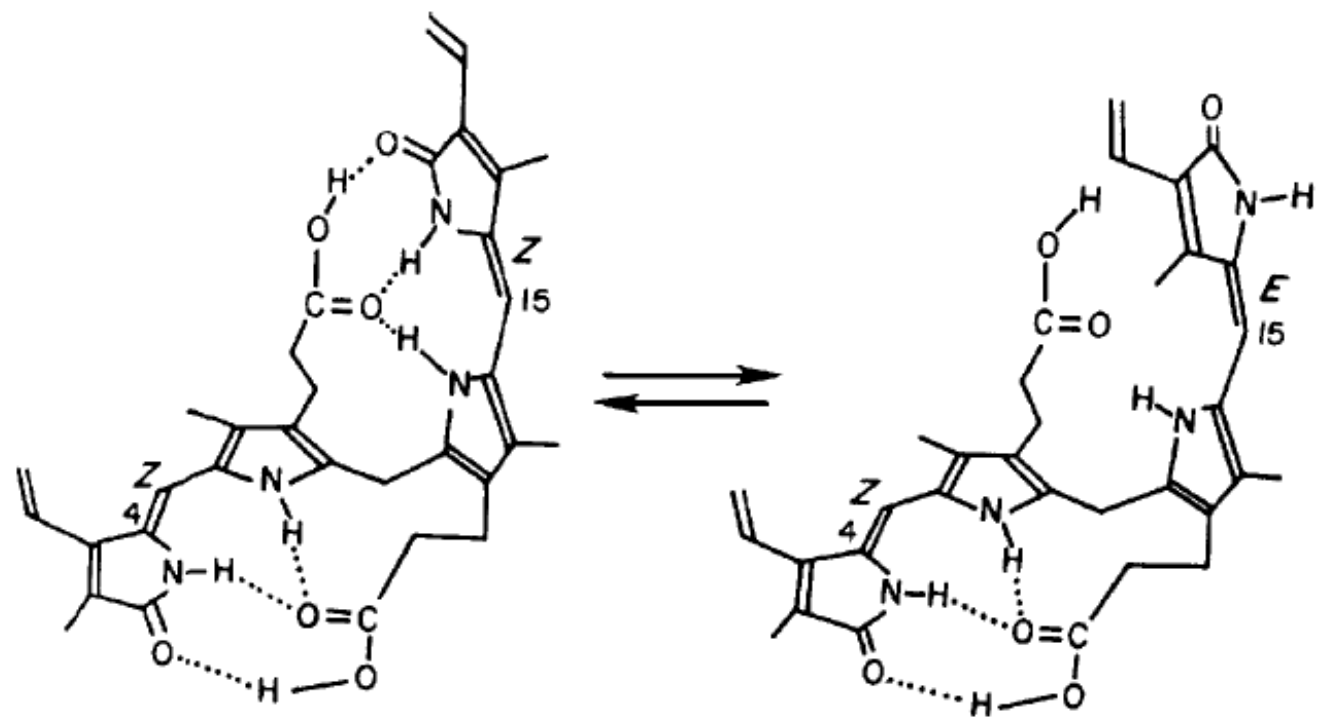

FIGURA 3.2- Foto-isomerização configuracional da bilirrubina (modificado de McDonagh e Lightner, 1985)

\subsubsection{Isomerização estrutural}

Nesta reação, ciclização intramolecular, a conversão da bilirrubina ocorre na presença de luz formando uma substancia conhecida como lumirrubina, que é expelida na bile e na urina, sem a necessidade de conjugação (FIG. 3.3). Durante o tratamento, a concentração de serum-lumirrubina varia de $2 \%$ a $6 \%$ consideravelmente abaixo da concentração do isômero configuracional (ao redor de $20 \%$ da bilirrubina total). A lumirrubina é retirada do sangue mais rapidamente do que o isômero 4Z15E. A meia-vida média da lumirrubina no sangue é menor do que 2 horas, comparada com as 15 horas para o isômero 4Z15E. Assim, embora o rendimento quântico para a isomerização configuracional seja pelo menos 40 vezes maior do que qualquer outra reação fotoquímica da bilirrubina, a taxa de eliminação do isômero $4 Z 15 E$ é tão lenta que não é importante no declínio da serum-bilirrubina observada no tratamento fototerápico de pacientes. A 
formação da lumirrubina é a principal foto-alteração responsável por este declínio. Além disso, a formação da lumirrubina não é uma reação reversível. Desta forma, uma vez convertida é eliminada pela bile ou urina sem ser modificada. (Ennever 1990, Maisels et.al., 1994).
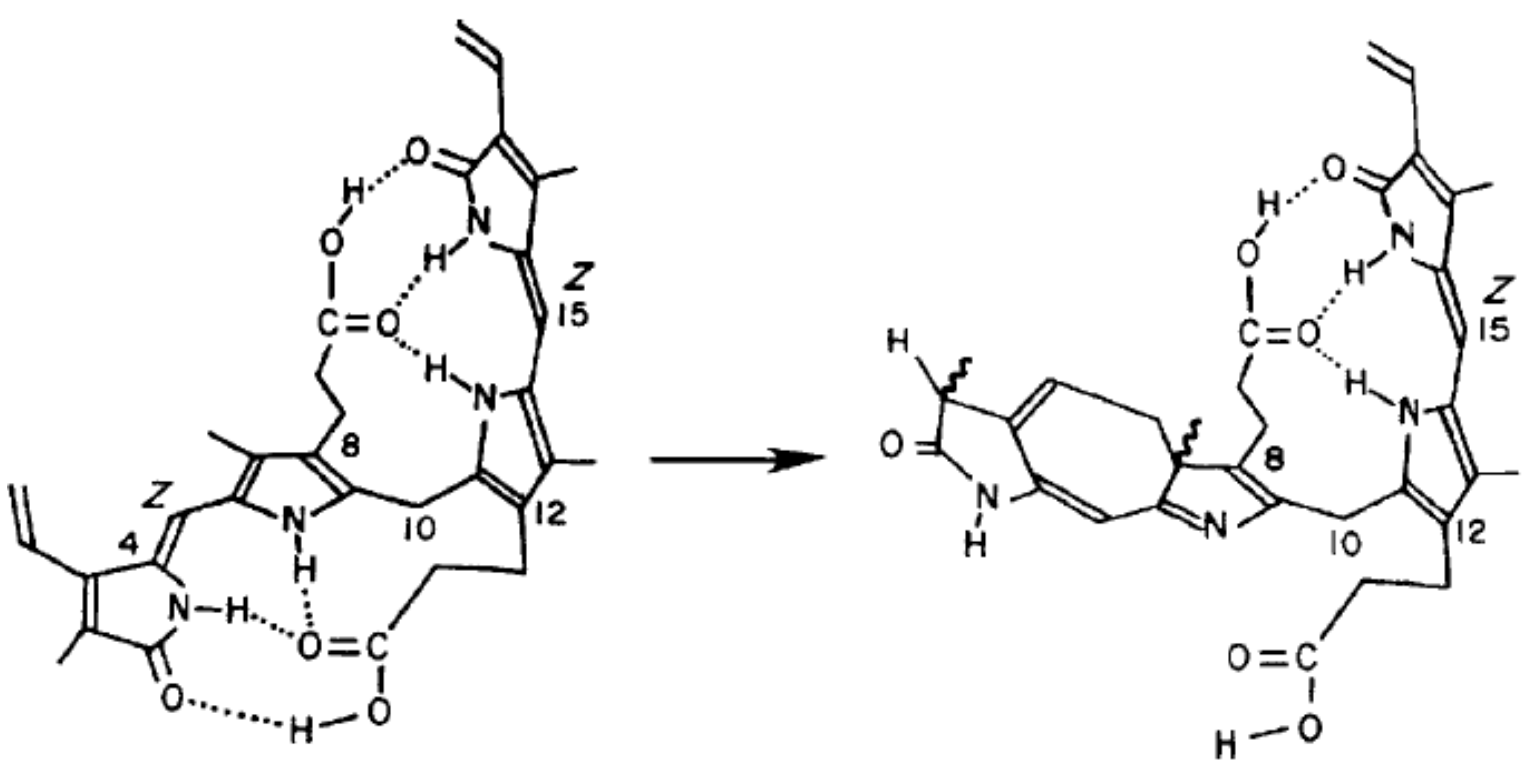

FIGURA 3.3 - Ciclização intramolecular da bilirrubina na presença de luz para a formação da lumirrubina (modificado de McDonagh e Lightner, 1985). 


\section{RADIOMETRIA}

Os radiômetros usados nas medições das irradiâncias de fontes de luz artificiais com espectros largos, ainda amplamente usadas no tratamento da icterícia de recém-nascidos, possuem exatidões conhecidamente baixas (AAP, 2004). A principal razão da baixa exatidão tem sido atribuída ao fato de que tais radiômetros são calibrados para uma fonte específica e grandes desvios ocorrem quando medem outra fonte (AAP, 2004). Mais especificamente, a diversidade de responsividades espectrais entre diferentes radiômetros tem sido apontada como fator relevante na baixa exatidão de tais radiômetros quando usados em outras fontes com espectros diferentes para o qual foram calibrados (Hammerman, 1981; Vreman, 2004; AAP, 2004). Assim um radiômetro "universal", capaz de medir qualquer fonte, tem sido apontado como uma solução altamente desejável (Vreman, 2004). Contudo, deveria estar claro na literatura que a avaliação do grau de conformidade de um radiômetro em teste com um medidor de referência requer um padrão. Mas um padrão de espectro de ação ainda é uma lacuna a ser preenchida na literatura da fototerapia da icterícia em neonatos.

Embora os fundamentos da calibração de radiômetros de bandas largas sejam conhecidos, não foi encontrado na literatura relacionada (fototerapia na icterícia neonatal) um método de calibração e de transferência de calibração. Também não foi encontrado um método de análise de erros resultantes da diversidade de responsividades espectrais ou de outros fatores relevantes que resultam erros nas medições. Buscando responder estas questões, neste capítulo são apresentados os fundamentos da radiometria ultravioleta de banda larga, elaborados seguindo os princípios da fotometria. Na seqüência será apresentado um novo enfoque sobre os fundamentos da radiometria de banda larga, adaptado à radiometria de interesse na fototerapia da icterícia de neonatos, evidenciando as relações entre a irradiância útil ao tratamento e a irradiância de uma fonte, sugerindo um processo de calibração, e expressando o erro resultante de um desajuste na responsividade espectral de um radiômetro resultante da medição de uma fonte com espectro diferente da fonte usada na calibração. Com esta abordagem é possível avaliar a relevância de um erro na responsividade espectral 
de um radiômetro, e compará-lo ao erro total em uma medição, quando a responsividade espacial também não é adequada, fator este ainda negligenciado pela literatura relacionada, mas de suma importância na composição dos fatores que resultam erros nas medições. Assim este capítulo apresenta um conjunto de métodos, ainda inexplorados na literatura relacionada, que apontam os parâmetros relevantes que devem ser medidos e informados, para que seja possível efetuar comparações entre fontes ou radiômetros diferentes.

\subsection{Fundamentos da radiometria de banda larga}

Os processos fotoquímicos envolvidos no tratamento da icterícia de recém-nascidos são dependentes do comprimento de onda da radiação luminosa. Assim, quando a fototerapia é promovida for fontes de radiação com espectros largos, somente parte da radiação é útil.

A irradiância efetiva ou eficaz $\left(E_{e f}\right)$ é uma quantidade radiométrica que representa a fração da radiação emitida pela fonte que efetivamente participa no processo de tratamento da icterícia em recém-nascidos, definida como:

$$
E_{e f}=\int_{0}^{\infty} S_{p}(\lambda) \cdot E(\lambda) d \lambda
$$

onde $S_{p}(\lambda)$ é uma curva de eficácia da radiação no tratamento (doravante denominada espectro de ação) com valor máximo normalizado e igual a um, e $E(\lambda)$ é a irradiância espectral de uma fonte luminosa em valores absolutos, expressa em $\left(\mathrm{W} / \mathrm{m}^{2} . \mathrm{nm}\right)$ ou mais comumente em $\left(\mu \mathrm{W} / \mathrm{cm}^{2} . \mathrm{nm}\right)$.

Para medir a irradiância eficaz pode ser usado um espectro-radiômetro (para conhecer a irradiância espectral), e calcular $E_{e f}$ usando (4.1). Mas geralmente é usado um radiômetro, cuja resposta espectral deveria seguir $S_{p}(\lambda)$, cuja construção é menos custosa e geralmente mais robusta. 
Geralmente um radiômetro destinado a medir a irradiância eficaz é construído usando uma aproximação de $S_{p}(\lambda)$ (limitações da tecnologia atual de construção de filtros ópticos), aqui expressa por $S_{a}(\lambda)$ (também normalizado), e apresenta como saída uma quantidade $Q$ proporcional a $E_{e f}$. Desta forma há um erro na medição da irradiância eficaz. Mas é possível calibrar o radiômetro, corrigindo este erro Xu e Huang (2003), usando a relação:

$$
R=\frac{Q}{E_{e f}}=\frac{Q}{\int_{0}^{\infty} S_{p}(\lambda) \cdot E_{1}(\lambda) d \lambda}
$$

ou

$$
R=\frac{\int_{0}^{\infty} S_{a}(\lambda) \cdot E_{1}(\lambda) d \lambda}{\int_{0}^{\infty} S_{p}(\lambda) \cdot E_{1}(\lambda) d \lambda}
$$

onde $E_{1}(\lambda)$ é a irradiância espectral de uma fonte (1) e R é o fator de calibração.

Para calibrar um radiômetro seguindo a equação (4.2), é necessário medir ou conhecer a irradiância espectral da fonte $E_{1}(\lambda)$. Para calibrar segundo a equação (4.3) é necessário medir ou conhecer $S_{a}(\lambda)$ e $E_{1}(\lambda)$, ou alternativamente conhecer a irradiância espectral relativa da fonte $E_{1(\text { rel) }}(\lambda)$ e a responsividade espectral do detector em valores absolutos: $s_{\max } \cdot S_{a}(\lambda)$, onde $s_{\max }$ é o valor máximo da responsividade (A/W.cm².nm) (Envall e Karha, 2006). Mas para obter $R$ são suficientes as responsividades e irradiâncias espectrais relativas. 
Segundo as equações (4.2) ou (4.3), um detector pode ser calibrado (resultando erro nulo) usando qualquer responsividade $S_{a}(\lambda)$, mesmo que $S_{p}(\lambda) \cdot S_{a}(\lambda)=0$ (sem qualquer sobreposição), mas a calibração somente é válida para medir fontes que tenham o mesmo espectro usado na calibração.

Caso outra fonte $E_{2}(\lambda)$ seja medida pelo mesmo detector com espectro de ação $S_{a}(\lambda)$, a relação (4.3) resulta $R_{2}, \mathrm{e}$

$$
\frac{R_{1}}{R_{2}}=\frac{\int_{0}^{\infty} S_{a}(\lambda) \cdot E_{1}(\lambda) d \lambda \cdot \int_{0}^{\infty} S_{p}(\lambda) \cdot E_{2}(\lambda) d \lambda}{\int_{0}^{\infty} S_{p}(\lambda) \cdot E_{1}(\lambda) d \lambda \cdot \int_{0}^{\infty} S_{a}(\lambda) \cdot E_{2}(\lambda) d \lambda}=r
$$

Deve ser notado em (4.4) que não há a necessidade de conhecer os valores absolutos dos espectros de ação e das irradiâncias espectrais das fontes: a constante $r$ pode ser calculada partindo dos irradiâncias espectrais e espectros de ação relativos (das fontes e do detector). Desta forma a medição da irradiância eficaz de uma fonte (2) efetuada com um medidor com espectro de ação aproximado $S_{a}(\lambda)$ e calibrado para a fonte (1) pode ser obtida multiplicando o valor medido por $r$.

Para avaliar um desajuste entre $S_{a}(\lambda)$ e $S_{p}(\lambda)$, o fator $f^{\prime}$ tem sido usado

$$
f^{\prime}=\frac{\int_{0}^{\infty}\left|S_{a}^{*}(\lambda)-S_{p}(\lambda)\right| d \lambda}{\int_{0}^{\infty} S_{p}(\lambda) d \lambda}
$$

onde $S_{a}^{*}(\lambda)=S_{a}(\lambda) / R$. Quando o ajuste é perfeito, $f^{\prime}=0$ e quando as responsividades estão totalmente separadas, $f^{\prime}=2$ (considerando que suas áreas sejam iguais), Xu e Huang (2003). 
As equações (4.2) e (4.3) têm sido usadas como base em calibrações radiométricas e a relação (4.4) tem sido usada para transferir a calibração de um radiômetro calibrado com uma determinada fonte para outra fonte, (Xu e Huang 2003, Envall e Karha, 2006).

As equações (4.2) e (4.3) podem ser usadas para calibrar um detector em teste, usando um medidor de referência (padrão). O medidor de referência usa um espectro de ação padrão. Erros de desajuste na responsividade espectral do detector em teste podem ser corrigidos parcialmente no processo de calibração, quando a fonte é a mesma. A calibração pode ainda ser transferida quando a fonte medida é outra. Assim tanto os princípios da radiometria de banda larga como os métodos mais recentes de calibração disponíveis na literatura (da radiometria na região ultravioleta) podem ser aplicados à radiometria na fototerapia da ictérica neonatal. Mas no caso dos radiômetros usados na fototerapia da icterícia de recém-nascidos, ainda não há um espectro de ação padrão. O espectro de ação segundo a norma DIN 5031-10 (2000) é aqui usado como padrão somente para demonstrar comparações (arrazoados no Capítulo 5). Buscando uma solução mais abrangente, na seqüência é apresentada uma nova abordagem sobre a radiometria de banda larga, elaborada durante a realização deste trabalho, que evidencia a relação entre a fonte e o radiômetro, e não entre radiômetros como acima exposto. A nova abordagem facilita o entendimento do método de calibração, de transferência de calibração para outra fonte, e de transferência de calibração para outro espectro de ação. Assim, caso outro espectro de ação seja usado, a quantidade "irradiância eficaz" aqui obtida pode ser corrigida. A abordagem seguinte também explicita: i) o erro decorrente do desajuste no espectro de ação de um detector (útil para saber o impacto nas medições quando o espectro de ação padrão muda) e ii) o erro quando um detector com espectro de ação aproximada é calibrado com uma fonte como espectro diferente da em teste (útil para quantificar este tipo comum de erro). Estes tópicos não são explorados na literatura da radiometria na fototerapia aqui tratada.

\subsection{Radiometria na fototerapia da icterícia neonatal}


Considerando que ou a fonte ou o espectro de ação ou ambas distribuições têm espectro com suporte limitado (são funções nulas fora do intervalo $\lambda_{1} \leq \lambda \leq \lambda_{2}$ ), a equação (4.1) pode ser expressa na forma

$$
E_{e f 1}=\int_{\lambda 1}^{\lambda 2} S_{p}(\lambda) \cdot E_{1}(\lambda) d \lambda
$$

Considerando por um momento que $S_{a}(\lambda)=1$ no intervalo $\lambda_{1} \leq \lambda \leq \lambda_{2}$ e zero fora na Eq. (4.3),

$$
\int_{\lambda 1}^{\lambda 2} S_{a}(\lambda) \cdot E_{1}(\lambda) d \lambda=E_{1}
$$

e (4.3) fica

$$
C_{p 1}=\frac{\int_{\lambda 1}^{\lambda 2} S_{p}(\lambda) \cdot E_{1}(\lambda) d \lambda}{\int_{\lambda 1}^{\lambda 2} E_{1}(\lambda) d \lambda}=\frac{E_{e f 1}}{E_{1}}
$$

onde $C_{p 1}$ é constante para a fonte (1), aqui denominada característica do detector para uma determinada fonte, e é a fração útil da irradiância da fonte, e assume valores $0<C_{p 1} \leq 1$.

Para um detector com espectro de ação aproximado $S_{a}(\lambda) \neq 1$, tem-se

$$
Q_{a 1}=\int_{\lambda 1}^{\lambda 2} S_{a}(\lambda) \cdot E_{1}(\lambda) d \lambda=C_{a 1} \cdot E_{1}
$$


onde $Q_{a 1}$ é a irradiância eficaz da fonte (1) quando medida com um detector com espectro de ação aproximado.

Combinando (4.8) e (4.9) tem-se:

$$
E_{e f 1}=\frac{C_{p 1}}{C_{a 1}} \cdot Q_{a 1}
$$

ou seja, uma medição efetuada com um medidor com espectro de ação aproximado pode ser corrigida conforme (4.10), desde que a fonte seja a mesma.

Usando as equações (4.8) e (4.9), é possível expressar o erro em uma medição de uma fonte decorrente do desajuste do espectro de ação

$$
\operatorname{Erro}(\%)=\frac{Q_{a 1}-E_{e f 1}}{E_{e f 1}} \cdot 100=\left[\frac{C_{a 1}}{C_{p 1}}-1\right] \cdot 100
$$

Para uma fonte (2), a equação (4.10) fica

$$
E_{e f 2}=\frac{C_{p 2}}{C_{a 2}} \cdot Q_{a 2}
$$


Usando as equações (4.10) e (4.12), a transferência de calibração de um radiômetro calibrado com a fonte (1) para medições de uma fonte (2) fica:

$$
E_{e f 2}=\frac{C_{a 1} \cdot C_{p 2}}{C_{p 1} \cdot C_{a 2}} \cdot Q_{a 2}
$$

Usando as equações (4.10) e (4.12), também é possível expressar o erro em uma medição de uma fonte (2) usando um radiômetro calibrado para a fonte (1) com espectro de ação aproximado, em função das características do detector

$$
\operatorname{Erro}(\%)=\left[\frac{C_{p 1} \cdot C_{a 2}}{C_{p 2} \cdot C_{a 1}}-1\right] \cdot 100
$$

Obviamente, quando o espectro de ação do detector é o padrão, $S_{p}(\lambda)$, o erro (4.14) é nulo para qualquer fonte.

\subsection{Responsividade espacial}

Irradiância é a potência da radiação luminosa incidente numa superfície por área elementar. É caracterizada pela quantia total de radiação incidente, em todas as freqüências. Na área elementar, o fluxo cai com o co-seno do ângulo de incidência. Portanto um detector destinado a medir a irradiância deve ter resposta co-senoidal. Uma pequena abertura (íris) delimitando a área sensível do detector efetuaria este papel. Mas o ângulo de acesso ficaria restrito, pois a abertura da íris, somada à de filtros e espaçadores (comumente presentes em detectores), limitam o ângulo de visão do detector. Assim, é comum o uso de um difusor com responsividade direcional aproximadamente co-senoidal. A superfície do difusor é então a superfície a ser considerada na medição da irradiância. Tais difusores geralmente respondem co-senoidalmente para uma vasta faixa de freqüências e 
para ângulos que se aproximam de noventa graus (exemplo, model D7, Bentham Instruments Limited, Berkshire, England).

Considerando que o difusor tenha resposta plana na faixa de comprimentos de onda em que o radiômetro responde e que seja homogêneo em toda sua superfície, a responsividade espacial (aqui denominada direcionalidade) de um radiômetro assim construído pode ser descrita, em coordenadas esféricas, na forma $I_{D}(\theta, \phi)=I \cdot \cos (\phi)$, onde $I_{D}$ é o sinal do detector e $I$ é a intensidade da radiação incidente, $-\pi / 2 \leq \phi \leq \pi / 2$ é o ângulo de incidência da radiação óptica e $0 \leq \theta \leq 2 \pi$ é o ângulo de azimute, tal que a quantidade medida, expressa em (4.1), fica ponderada por $\cos (\phi)$.

Quando a responsividade espacial do detector se afasta da cosenoidal, a quantidade medida desvia da real. Tal desvio geralmente é expresso pelo erro co-seno $E_{c}$ :

$$
E_{c}(\theta, \phi)=\frac{I_{c}(\theta, \phi)}{I_{c}(\theta, \phi=0) \cdot \cos (\phi)}
$$

onde $I_{c}(\theta, \phi=0)$ é o valor do sinal do detector quando a radiação é normal à sua superfície.

O efeito do erro co-senoidal pode ser compensado, aplicando um fator de correção, que depende do erro co-senoidal e da distribuição da radiação óptica (Cordero et al., 2008). Contudo, enquanto a distribuição da radiação óptica pode ser mais facilmente modelada ou mapeada quando a fonte é pontual, o mesmo não se aplica a fontes estendidas. A correção também é possível seguindo os mesmos princípios da calibração espectral: confrontando um detector calibrado contra o detector em teste. Entretanto a dificuldade da compensação do erro cosenoidal aumenta drasticamente quando comparada à da correção espectral, pois o fator de correção varia no espaço. Portanto, enquanto é possível calibrar um radiômetro com qualquer responsividade espectral para uma determinada fonte usando somente um fator de correção, quando o detector não responde cosenoidalmente, seria necessário usar um fator de correção para cada localização 
espacial do detector na superfície onde uma fonte é útil, tornado o processo corretivo impraticável.

\subsection{Quantidades medidas}

Segundo Vreman et al. (2004) uma vez que a irradiância eficaz é medida na faixa espectral onde o processo de isomerização da bilirrubina ocorre com eficácia, tem sido comum expressar a quantidade medida em $\left(\mu \mathrm{W} / \mathrm{cm}^{2} \cdot \mathrm{nm}\right)$, apresentando a mesma dimensão de irradiância espectral. Segundo Maisels (2001) a nova quantidade "irradiância espectral" expressa a irradiância em uma "certa" faixa de comprimentos de onda.

Embora não tenha sido encontrada na literatura a razão de expressar essa nova quantidade, a "irradiância espectral" é obtida dividindo a irradiância eficaz, conforme definida pela Eq. (4.1), por uma "certa" faixa de comprimentos de onda. O grande problema encontrado durante o desenvolvimento do presente trabalho foi a ausência, na literatura, de uma definição clara sobre a quantidade "certa faixa de comprimentos de onda". Como um exemplo, nas diretrizes "Management of hyperbilirubinemia in the new born infant 35 or more weeks of gestation" (AAP, American Academy of Pediatrics, 2004), há quantidades radiométricas expressas em $\left(\mu \mathrm{W} / \mathrm{cm}^{2} \cdot \mathrm{nm}\right)$ que são originariamente expressas por Tan (1982) em $\left(\mu \mathrm{W} / \mathrm{cm}^{2}\right)$. Comparando os mesmos valores nos dois textos, a razão entre eles é exatamente $50 \mathrm{~nm}$; supostamente uma faixa espectral onde o conjunto radiômetro e filtro óptico usado por Tan é sensível, indicada ser "425-475 nm" sic. A faixa passante de filtros ópticos passa-bandas é comumente especificada usando o conceito de largura da banda passante à meia altura do pico (full width at half maximum, FWHM). Contudo não há, no trabalho de Tan, qualquer arrazoado sobre o significado de tal faixa. Ou seja, não foi informado o método usado para quantificar a faixa espectral onde o conjunto radiômetro e filtro óptico usado por Tan é sensível. Em adição, as larguras informadas na literatura são variadas. Como exemplos, faixas de 40 nm, 50 nm, 80 nm são encontradas (Tan, 1982).

Embora seja desnecessária a nova quantidade acima descrita (irradiância espectral), uma vez conhecida a largura espectral, é possível conhecer a irradiância eficaz: basta multiplicar o valor da "irradiância espectral" 
pela faixa passante usada. Mas, uma vez que na literatura relacionada raramente é citada a faixa passante usada, raramente é possível saber a irradiância eficaz.

Além de ser desnecessária a nova quantidade "irradiância espectral", o procedimento de dividir a irradiância eficaz por uma "certa" faixa de comprimentos de onda significa dificultar comparações. Considere uma fonte azul com espectro limitado entre $400 \mathrm{~nm}$ a $550 \mathrm{~nm}$, com irradiância igual a $1 \mathrm{~W} / \mathrm{m}^{2}$. Considere agora dois radiômetros medindo a fonte: um com espectro de ação plano entre $400 \mathrm{~nm}$ a $550 \mathrm{~nm}$ e outro com espectro de ação plano entre $420 \mathrm{~nm}$ e $480 \mathrm{~nm}$. As irradiâncias espectrais medidas são $1 / 150 \mathrm{~W} / \mathrm{m}^{2} \cdot \mathrm{nm}$ e $1 / 60 \mathrm{~W} / \mathrm{m}^{2} \cdot \mathrm{nm}$ respectivamente.

\subsection{Dose}

O efeito desejado - a diminuição dos níveis de bilirrubina - depende, dentre outros fatores, da irradiância, da área irradiada e do tempo de exposição (Vreman et al., 2004). Embora a dependência do efeito desejado com estes fatores não seja necessariamente linear, o conceito de dose em fototerapia na área relacionada com a icterícia neonatal tem sido a irradiância (Vreman et al., 2004). Contudo, num sentido mais amplo em fototerapia, o conceito de dose tem sido a exposição radiante, expressa em $\mathrm{J} / \mathrm{m}^{2}$ (Sliney, 2007). 


\section{MATERIAL E MÉTODOS}

Para atender aos objetivos propostos, a metodologia descrita no Capítulo 4 foi aplicada a dois radiômetros e duas fontes fototerápicas disponíveis no mercado nacional, aqui descritas. As calibrações foram realizadas usando um espectro-radiômetro. No entanto o uso de um espectro-radiômetro convencional dificultaria as medições nas fontes, pois geralmente possuem elevadas dimensões e necessitam de uma esfera integradora. A solução encontrada foi construir um espectro-radiômetro portável, partindo de um mini-espectrômetro, atualmente disponível com baixo custo.

A caracterização das fontes ensaiadas, no entanto, requer métodos também ainda não padronizados, pois os feixes luminosos das fontes fototerápicas não são uniformes. Assim este capítulo também descreve um novo método de medição e cálculo da irradiância eficaz média para as fontes com foco dirigido. As demais fontes foram caracterizadas usando métodos padronizados.

\subsection{Unidades de fototerapia e radiômetros comerciais}

Neste trabalho optou-se pela análise de equipamentos clínicos de fabricação nacional, pois são raros os trabalhos publicados onde conste a caracterização destes equipamentos (nacionais).

As quatro unidades de fototerapia ensaiadas estão descritas a seguir:

a) Unidade de fototerapia marca Fanem (Fanem Ltda, Brasil), modelo Bilispot 006BP, dotado de uma lâmpada incandescente de $75 \mathrm{~W}$, com refletor dicróico marca Fanem, modelo 006.365.025 (Fanem Ltda, Brasil) e alimentada por tensão nominal de $220 \mathrm{~V}$, doravante denominado $\mathbf{H} 1$.

b) Unidade de fototerapia marca Fanem (Fanem Ltda, Brasil), modelo Octofoto 006-OFL, contendo oito lâmpadas fluorescentes tubulares formando uma luminária plana. A distribuição das lâmpadas é a seguinte: quatro lâmpadas de $20 \mathrm{~W}$ modelo TL20W/52, marca Philips (Koninklijke Philips Electronics N.V., 
Netherlands) emitindo luz azul posicionadas na região central e quatro lâmpadas Luz do Dia de 20 W, modelo TLT20W/75RS-Extra, marca Philips (Philips do Brasil Ltda, Brasil) emitindo luz branca posicionadas duas a duas nas laterais. $\mathrm{O}$ conjunto foi alimentado por tensão de $110 \mathrm{~V}$, doravante denominado F1.

c) Unidade de fototerapia marca Gigante GRN (Gigante Recém-Nascido Indústria, Comércio e Representações Ltda, Brasil), modelo F8-P, contendo oito lâmpadas fluorescentes tubulares formando uma luminária plana. A distribuição das lâmpadas é a seguinte: quatro lâmpadas de $20 \mathrm{~W}$, modelo TL20W/52, marca Philips (Koninklijke Philips Electronics N.V., Netherlands) emitindo luz azul posicionadas na região central e quatro lâmpadas Luz do Dia de $20 \mathrm{~W}$, marca GE (General Electric, Brasil) emitindo luz branca posicionadas duas a duas nas laterais. O conjunto foi alimentado por tensão de $110 \mathrm{~V}$, doravante denominado F2.

d) Unidade de fototerapia marca Gigante (Gigante Recém-Nascido Indústria, Comércio e Representações Ltda, Brasil), modelo H 100 A, dotado de uma lâmpada incandescente de $80 \mathrm{~W}$, com refletor dicróico, e alimentada por tensão nominal de $220 \mathrm{~V}$, doravante denominado $\mathbf{H 2}$.

Os dois radiômetros comerciais usados neste trabalho foram os seguintes:

a) Monitor de radiação marca Fanem (Fanem Ltda, Brasil), modelo 620, constituído por um indicador digital de três dígitos, com resolução de 0,1 $\mu \mathrm{W} / \mathrm{cm}^{2} \mathrm{~nm}$, faixa nominal de zero a $99.9 \mu \mathrm{W} / \mathrm{cm}^{2} \mathrm{~nm}$, diâmetro do difusor 12 $\mathrm{mm}$, doravante denominado $\mathbf{R} \mathbf{1}$.

b) Radiômetro marca Gigante (Gigante Recém -Nascido Indústria, Comércio e Representações Ltda, Brasil), modelo GND, constituído por um indicador digital de três dígitos, com resolução de $0,1 \mu \mathrm{W} / \mathrm{cm}^{2} \mathrm{~nm}$, faixa nominal de zero a $99.9 \mu \mathrm{W} / \mathrm{cm}^{2} \mathrm{~nm}$ na faixa espectral de $420 \mathrm{~nm}$ a $495 \mathrm{~nm}$, diâmetro do difusor 12,8 $\mathbf{m m}$, doravante denominado $\mathbf{R} \mathbf{2}$. 


\subsection{Espectro-radiômetro}

Para o estabelecimento das medidas de referência e calibrações espectro-radiométricas foi usado um espectro-radiômetro, cujas medições são consideradas, neste trabalho, como valores de referência.

O espectro-radiômetro é composto por um espectrômetro portátil marca Ocean Optics (Ocean Optics Inc., USA), modelo USB-4000, dotado de CCD com 3648 elementos e resposta espectral na faixa entre $220 \mathrm{~nm}$ e $1050 \mathrm{~nm}$ acoplado a uma sonda via fibra óptica para a coleta de radiação. A sonda possui um corretor co-senoidal com difusor de PTFE e diâmetro de 3,9 mm marca Ocean Optics (Ocean Optics Inc., USA), modelo CC-3-UV, e um cabo de fibra óptica marca Ocean Optics (Ocean Optics Inc. -USA), modelo QP-600-2-UV-VIS.

O espectro-radiômetro foi calibrado com o emprego de um conjunto de fontes calibradas, marca Ocean Optics, modelo DH2000-CAL Deuterium Tungsten Halogen Calibration Standard (Ocean Optics Inc., USA), cuja calibração é rastreada junto ao NIST (National Institute of Standards and Technology -USA), e do programa Spectrasuite Spectroscopy Operating Software, marca Ocean Opitcs (Ocean Optics Inc.- USA). Este software é dotado de uma rotina de calibração que, em conjunto com os padrões do sistema DH2000, permitem executar a calibração da resposta espectral do espectro-radiômetro, com incerteza de calibração de $\pm 5 \%$. A calibração habilita 0 instrumento para a medição de irradiância espectral no intervalo de $220 \mathrm{~nm}$ a $1050 \mathrm{~nm}$, com resolução de aproximadamente $0,29 \mathrm{~nm}$ de comprimento de onda ao longo de toda a faixa.

Para facilitar as comparações, doravante o conjunto que constitui o espectro-radiômetro será denominado ER.

Uma vez que as fontes F1 e F2 são pulsáteis, foram usados tempos longos de integração no espectro-radiômetro, variando entre $50 \mathrm{~ms}$ a $100 \mathrm{~ms}$. Cada espectro medido resultou da média de uma série de dez espectros medidos consecutivamente, após cada intervalo de integração. Os intervalos de integração usados nas calibrações foram mantidos nas medições. 


\subsection{Medições}

As irradiâncias das fontes foram medidas usando os radiômetros $\mathrm{R} 1 \mathrm{e}$ R2, e calculadas usando o espectro-radiômetro ER, cujos espectros medidos foram ponderados por um espectro de ação abaixo descrito. Os locais das medições bem como os métodos de cálculo das irradiâncias médias das fontes são apresentados na seqüência.

\subsubsection{Irradiância eficaz}

Um espectro de ação deveria ponderar a irradiância espectral da fonte tal que a irradiância eficaz resultante a relacione com o decréscimo da bilirrubina. Muitos radiômetros foram construídos com filtros ópticos buscando um ajuste ao espectro de absorção da bilirrubina. Mas a efetividade espectral da foto-alteração não coincide necessariamente com o espectro de absorção. Como um exemplo, o espectro do rendimento quântico de formação de lumirrubina não coincide com o espectro de absorção (Agati et al.., 1993). Uma série de outros fatores contribui para que ainda não exista um espectro de ação padrão aceito na literatura (Maisels, 1996; NBR-IEC 60601-2-50:2000).

No presente trabalho foi arbitrariamente adotado como padrão 0 espectro de ação da bilirrubina prescrito na norma DIN 5031-10 (2000).

A norma NBR 60601.2-50:2003 (é a correspondente IEC 60601-250:2000), que trata de equipamentos fototerápicos, não adota um espectro de ação, mas prescrevem a faixa de efetividade (entre 400nm a 550nm), e citam como razão o trabalho de Ballowitz et al.. (1977) e a norma DIN acima citada. De fato, a NBR 60601.2-50:2003 adota um espectro de ação plano entre 400nm e $550 \mathrm{~nm}$, mas reconhece que, embora não haja consenso acerca de um espectro de ação, a efetividade do tratamento depende da distribuição espectral da fonte.

A NBR-IEC 60601-2-50 é norma particular da série de norma NBR-IEC60601-2-X, que é referida no Programa Brasileiro de Qualidade de Produtos Correlatos. Este programa visa essencialmente garantir a qualidade e a segurança dos produtos controlados (pela Anvisa - Agencia Nacional de Vigilância Sanitária), recorrendo às normas técnicas que prescrevem requisitos mínimos de qualidade e segurança que uma série de produtos eletro-médicos devem atender. A NBR-IEC 60601-2-50:2003, está em concordância com a 
equivalente IEC 60601-2-50, que é uma norma internacional adotada por mais de 50 paises.

A irradiância eficaz, segundo o espectro de ação da norma DIN [E $\left.E_{D I N}\right]$ é obtida a partir da equação (4.1) onde o espectro de ação adotado $S_{p}=S_{D I N}$ :

$$
E_{D I N}=\int_{\lambda 1}^{\lambda 2} E(\lambda) \cdot S_{D I N}(\lambda) d \lambda
$$

\subsubsection{Irradiância eficaz média}

A irradiância eficaz das unidades de fototerapia F1 e F2, que usam lâmpadas fluorescentes (FIG 5.1), são distribuídas na área da superfície efetiva para o tratamento, que é correspondente a uma secção de formato retangular de 0,3m por 0,6 m conforme prescreve a NBR-IEC 60601-2-50: 2003 (FIG. 5.2), onde o neonato é posicionado.

Mas a irradiância também depende da distância entre o neonato e a fonte: a irradiância da fonte cai com a distância. Na literatura há uma variação significativa de distâncias entre fontes com lâmpadas fluorescentes e a superfície efetiva. Alguns pesquisadores adotam $10 \mathrm{~cm}$ (AAP 2004; Maisels e Watchko, 2003), outros $40 \mathrm{~cm}$ (Dicken, 2000). De Carvalho (1999) e Colveiro et al.,( 2005) utilizaram a distância de $30 \mathrm{~cm}$, e justificam que para distâncias menores há uma dificuldade na visualização e manipulação do paciente, além do risco de aquecimento pela proximidade entre a unidade de fototerapia e o neonato.

Pela falta de consenso quanto às distâncias mínimas entre o paciente e a fonte, adotou-se neste trabalho a distância $25 \mathrm{~cm}$ para as medições das unidades de fototerapia com lâmpadas fluorescentes, seguindo em parte as razões de De Carvalho (1999) e Colveiro et al.(2005), ou seja, a mínima distância segura. A mínima distância segura significa a máxima irradiância disponível. 


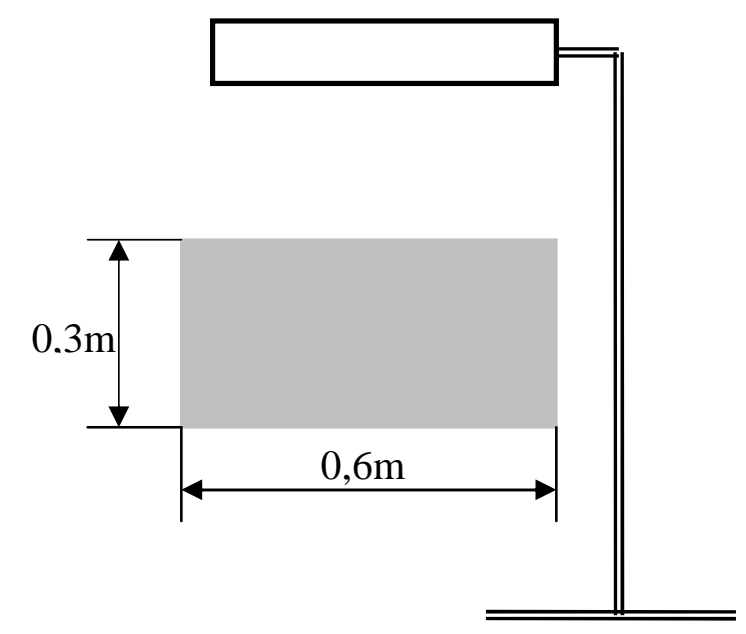

FIGURA 5.1 - Unidades de fototerapia fluorescentes

A irradiância eficaz média disponível em cada unidade fototerápica com lâmpadas fluorescentes foi obtida calculando-se a média aritmética dos valores das irradiâncias eficazes medidas nos pontos indicados na FIG. 5.2, conforme prescreve a norma NBR IEC 60601.2.50: 2003.

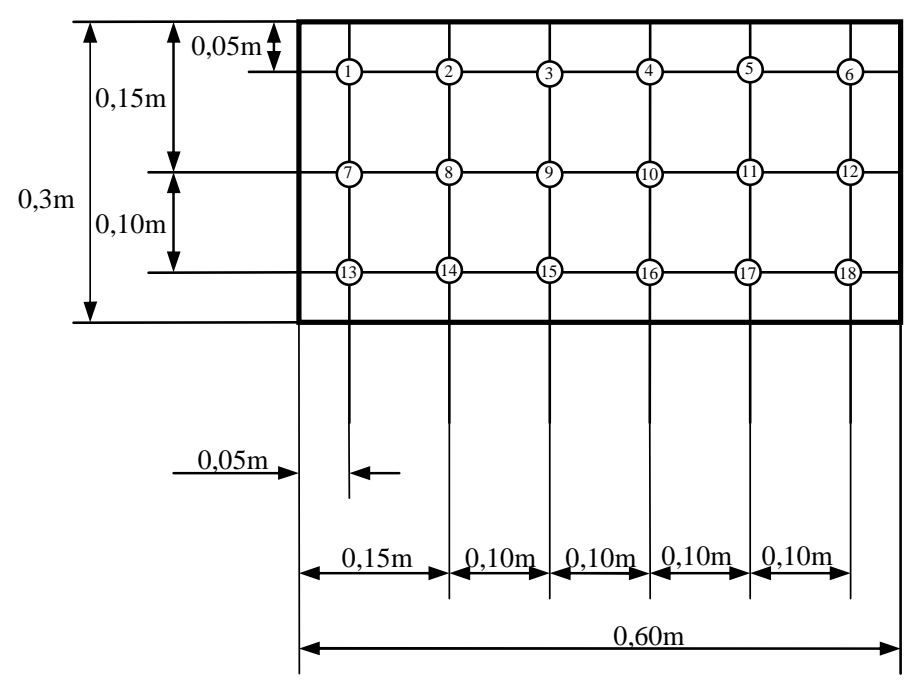

FIGURA 5.2 - Distribuição dos pontos de medição para as fontes fluorescentes

As unidades halógenas $\mathrm{H} 1$ e $\mathrm{H} 2$ possuem focos dirigidos, dotadas de uma lâmpada halógena dicróica, e de um conjunto de lentes de Fresnel, para a construção e direcionamento de um feixe concentrado de radiação, além de filtros de banda para a seleção do comprimento de ondas convenientes ao tratamento. A emissão óptica deste conjunto é cônica e quando projetada perpendicularmente a uma superfície plana produz um circulo iluminado de bordas bem definidas, 
(Fachini, 2001). Mas, conforme recomendações dos fabricantes, os cabeçotes destas unidades de fototerapia devem ser posicionados em ângulos de aproximadamente $45^{\circ}$, e posicionadas a $450 \mathrm{~mm}$ de distância. Nesta condição a área iluminada na superfície efetiva torna-se elíptica, em virtude do conjunto óptico empregado (FIG. 5.3.). Os valores dos eixos das elipses projetadas por $\mathrm{H} 1$ e H2 na distância e ângulo sugeridos pelos fabricantes são $12 \mathrm{~cm} \times 15 \mathrm{~cm}$ e 14 $\mathrm{cm} \times 19 \mathrm{~cm}$ respectivamente.

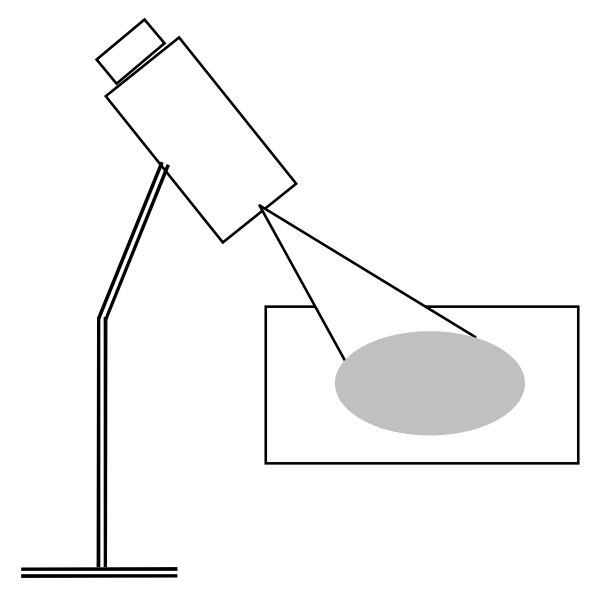

FIGURA 5.3 - Projeção Elíptica do feixe de luz nas unidades halógenas

A norma NBR IEC 60601-2-50: 2003 não prescreve uma distribuição de pontos ao longo da superfície irradiada pela unidade de fototerapia quando o foco é elíptico.

$\mathrm{Na}$ literatura a maioria das propostas para a avaliação equipamentos de fototerapia que usam lâmpadas halógenas sugere a medição da irradiância eficaz em uma região central da área iluminada (área da superfície efetiva), ou em três posições no eixo central, correspondentes às posições da cabeça, tronco e pernas (Tan, 1982; Dicken, 2000).

Fachini (2001) propõe a medição da irradiância espectral média em uma projeção circular de $15 \mathrm{~cm}$ de diâmetro, que é obtida quando o cabeçote é posicionado perpendicularmente a uma superfície plana, a $50 \mathrm{~cm}$ de distância. $O$ valor da irradiância espectral média é obtido conforme segue: o círculo projetado é subdividido em três áreas concêntricas obtidas pelo traçado de duas 
circunferências adicionais de $2,5 \mathrm{~cm}$ e $5 \mathrm{~cm}$ de raios, que desta forma dividem o círculo em uma área circular e duas anelares (A, B e C respectivamente), conforme mostra a FIG.5.4. Em cada uma dessas áreas são marcados quatro pontos conforme mostra a FIG.5.4. A média aritmética das irradiâncias medidas nos pontos localizados em cada anel (e no círculo interno) é multiplicada pela área do anel (e do círculo interno). Os três valores resultantes são somados e o resultado é dividido pela área total (do círculo maior), resultando a irradiância espectral média do feixe terapêutico. A medição foi feita com um radiômetro semelhante ao R1.

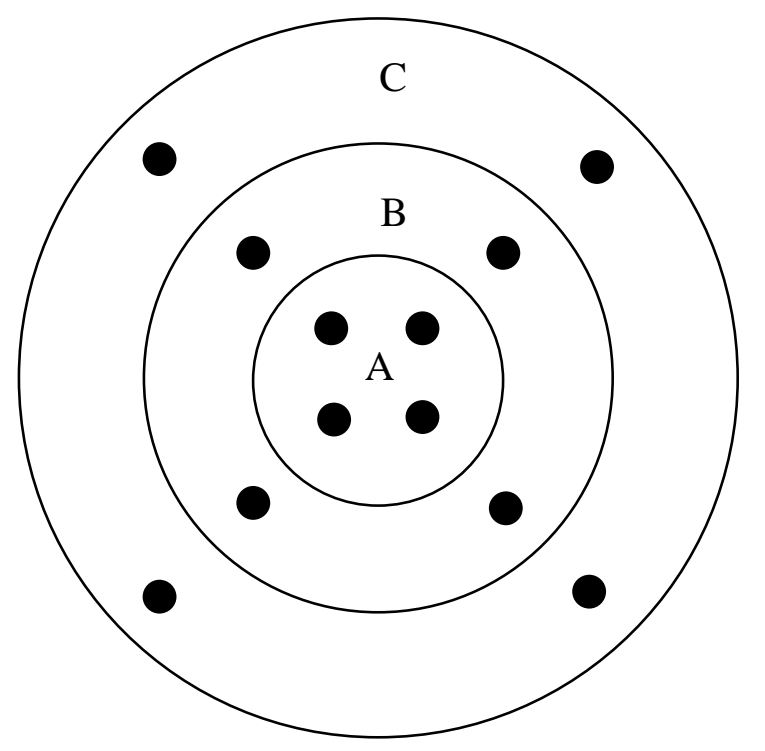

FIGURA 5.4 - Disposição de pontos proposta por Fachini (2001) (modificado de Fachini, 2001).

Segundo Fachini (2001), o método acima descrito objetiva estimar a irradiância eficaz média que incide sobre um círculo no plano da superfície de referência. No presente trabalho é sugerido um método para projeções elípticas, derivado do método proposto por Fachini (2001), conforme é descrito na seqüência.

A estimativa da irradiância eficaz média nas fontes halógenas requer uma distribuição de pontos que considere as elevadas variações da irradiância ao longo da superfície efetiva. Desta forma, foram adotados, arbitrariamente, setores da elipse com intervalos angulares de $45^{\circ}$ a partir do seu centro (intersecção dos eixos maior e menor), cada setor subdividido radialmente de forma eqüitativa em dois anéis elípticos e uma elipse menor no centro, perfazendo 24 regiões e 24 pontos de medição. As medições foram realizadas nos pontos 1 a 24 de cada 
região (FIG.5.5). Entretanto, considerar, para efeito da estimação da irradiância eficaz média, a média aritmética dos valores medidos nos pontos localizados em cada anel elíptico e elipse menor implicaria numa aproximação grosseira, pois nem todas as áreas de cada uma das 24 regiões (onde há pontos de medição) são iguais. Assim, foram consideradas as potências que incidem em cada setor.

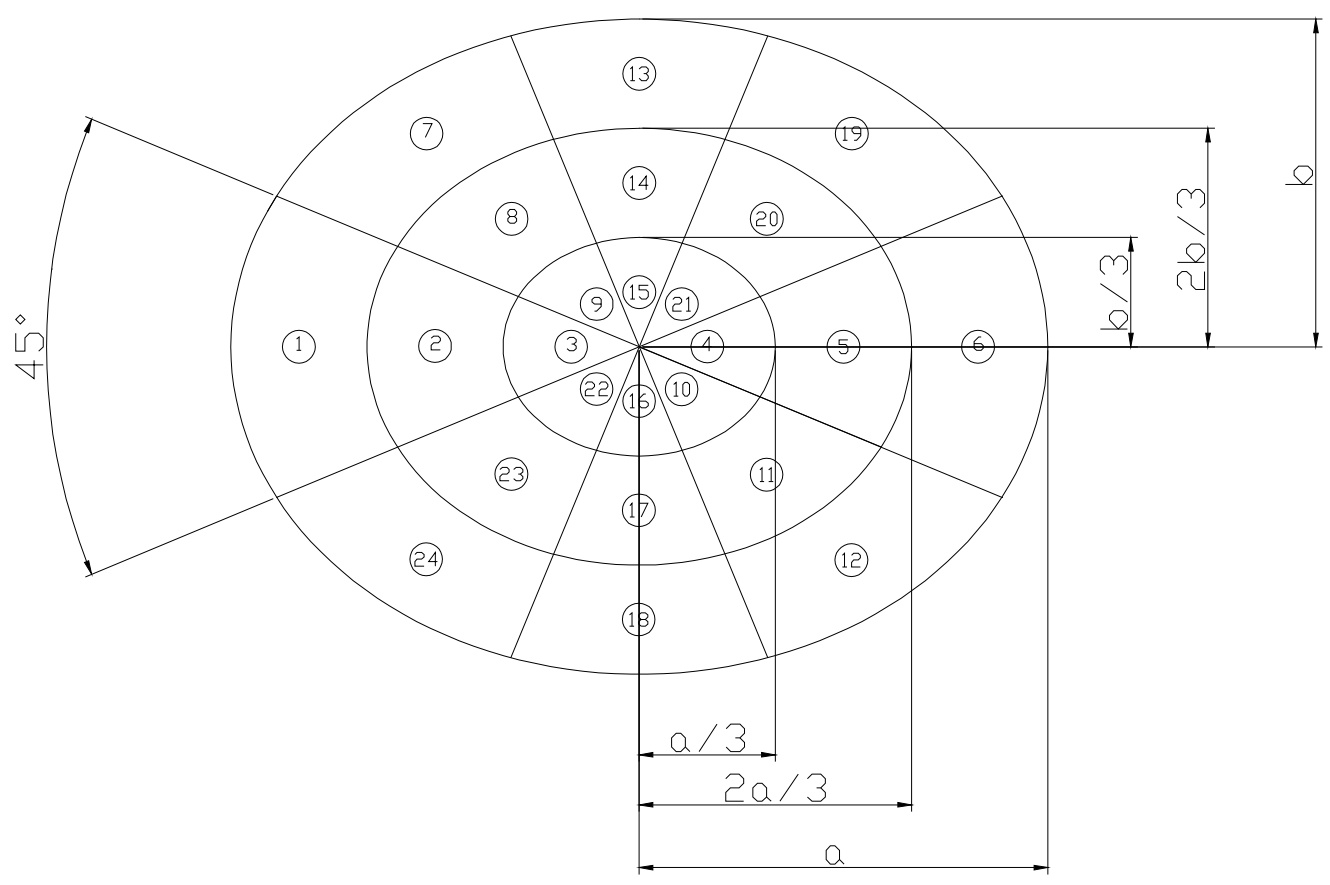

FIGURA 5.5 - Distribuição dos pontos de medição para fontes halógenas

A estimação da irradiância eficaz média faz-se pelo cálculo da potência efetiva de tratamento em cada setor da elipse, ou seja:

$$
P_{n}=E_{n} \cdot A_{n}
$$

onde $E_{n}$ é a irradiância medida no ponto $n=1 \ldots 24$, e $A_{n}$ é a área de cada região, e $P_{n}$ é, portanto, uma estimativa da potência da radiação luminosa que incide em cada uma das 24 regiões da elipse.

A estimativa de irradiância média eficaz de tratamento é então

$$
\overline{E_{e f}}=\frac{\sum_{1}^{24} P_{n}}{\sum_{1}^{24} A_{n}}
$$




\subsection{Caracterização dos radiômetros}

As responsividades espectrais dos radiômetros ensaiados foram obtidas dos fabricantes, e apresentadas a seguir. No entanto, enquanto a responsividade espacial (direcionalidade) da sonda de ER foi fornecida pelo fabricante, as correspondentes de R1 e R2 foram medidas.

\subsubsection{Resposta espacial do fotodetector}

O levantamento da curva de resposta espacial foi obtido usando o arranjo esquematizado na FIG. 5.6. Como fonte de luz foi usado um laser marca Coherent (Coherent Inc., USA), modelo Cube Laser System, emitindo em 405 nm, potência máxima de $90 \mathrm{~mW}$ e diâmetro de feixe igual a $1 \mathrm{~mm}$. Para evitar danos nos sensores, a radiação foi atenuada aproximadamente 150 vezes.

No arranjo usado o feixe incide ortogonalmente e geometricamente centrado à superfície detectora do radiômetro. Também é importante que o plano da superfície detectora esteja alinhado com o eixo de rotação da mesa do goniômetro. Após o posicionamento, o radiômetro foi angularmente deslocado em intervalos de $5^{\circ}$ tanto no sentido horário como no a nti-horário. A resposta cosenoidal é comumente expressa como a razão da resposta medida pela resposta co-senoidal ideal. 


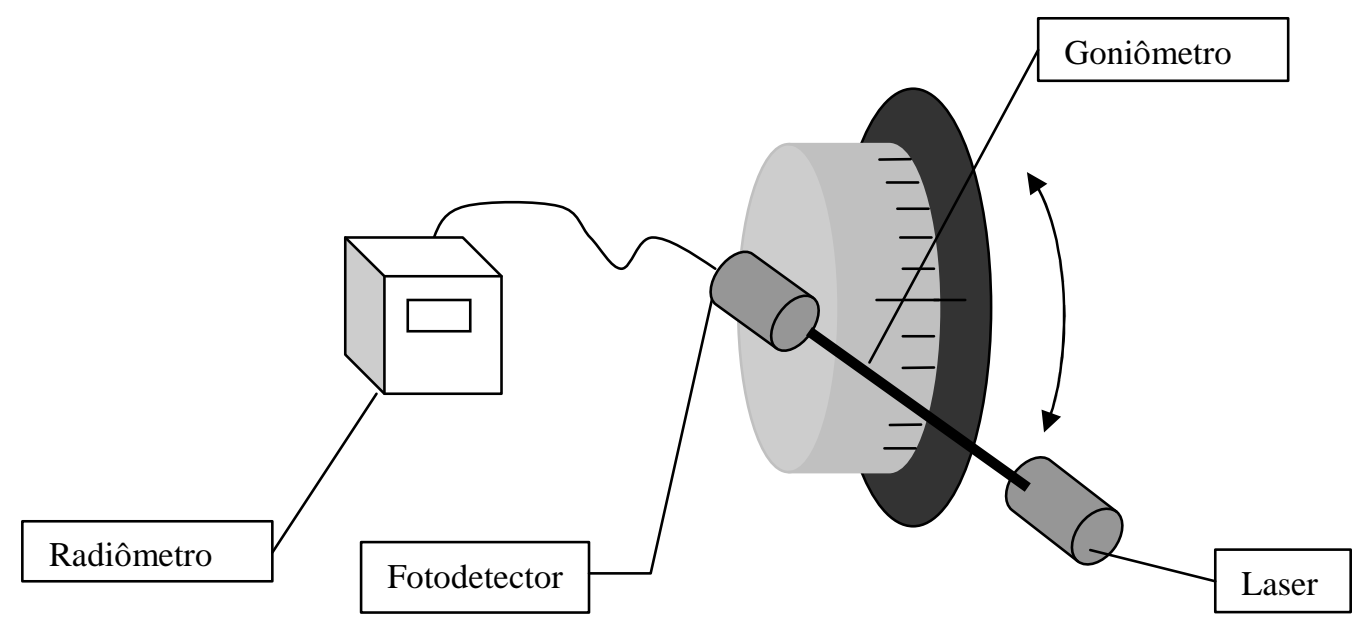

Figura 5.6 - Esquema de montagem para levantamento da responsividade espacial

\subsubsection{Resposta espectral do fotodetector}

Os valores de responsividade espectral usados são aqueles fornecidos pelos fabricantes.

A FIG. 5.7 mostra os valores de responsividades espectrais de R1 e R2, bem como o espectro de ação usado (DIN 5031-10). Também é mostrada no mesmo gráfico uma curva gaussiana com desvio-padrão igual a $26 \mathrm{~nm}$ e pico igual a $460 \mathrm{~nm}$, aqui doravante expressa como $\mathrm{G}(460,26) \mathrm{nm}$.

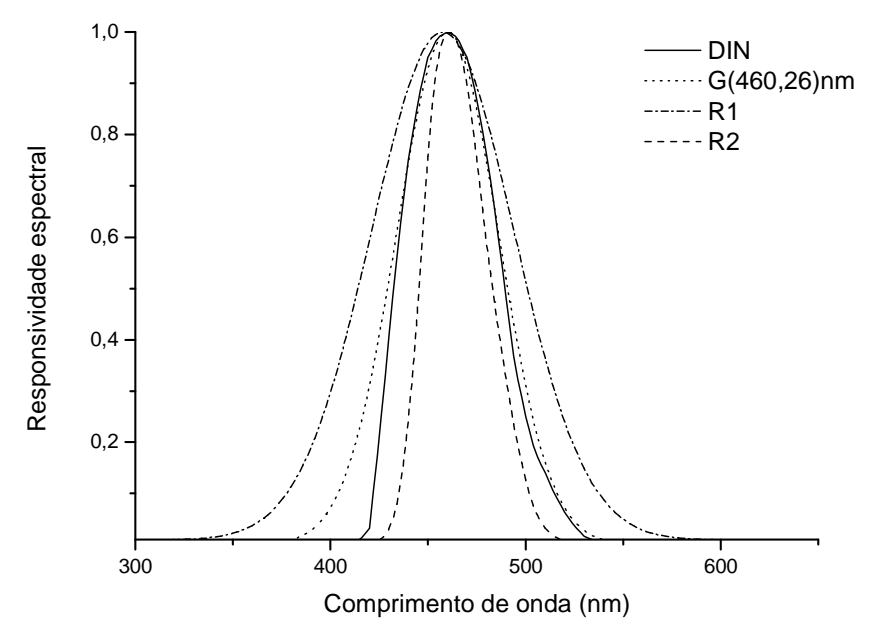

FIGURA 5.7 - Curvas de Responsividades espectrais dos detectores R1, R2, espectro de ação DIN e de uma gaussiana $\mathrm{G}(460,26) \mathrm{nm}$. 


\subsubsection{Determinação das características dos radiômetros}

As características dos radiômetros R1 e R2 foram determinadas usando a Eq. (4.8), partindo dos valores medidos pelos radiômetros e por ER, para as fontes $\mathrm{F} 1, \mathrm{~F} 2$, $\mathrm{H} 1$ e H2.

\subsubsection{Quantificação dos erros espaciais}

Para verificar se os radiômetros ensaiados respondem espacialmente conforme ER foi verificada a diferença percentual entre R1 ou R2 e ER em cada ponto das superfícies efetivas. Mas R1 e R2 medem "irradiância espectral" e ER mede irradiância: portanto não podem ser comparados diretamente. Em adição, não são informados os critérios usados nas calibração de R1 e R2. Caso fossem informados seria possível converter suas saídas para que indicassem irradiância. Uma alternativa possível para contornar este problema seria calibrar ER para medir irradiância espectral. Mas, segundo as razões apontadas no Capítulo 4, não há definição única na literatura da largura espectral que resulta a quantidade "irradiância espectral". Assim os resultados das comparações seriam limitados. Outra alternativa, seria desprezar a calibração do fabricante (de R1 e R2), e calibrar R1 e de R2 contra ER segundo a Eq. (4.2) usando uma fonte com feixe uniforme, de tal forma que R1 e R2 indiquem irradiâncias, tomando como referência o espectro de ação DIN. A fonte de calibração não poderia ser as unidades fototerápicas ensaiadas, pois não produzem feixes uniformes em regiões mensuráveis. Ou seja, afastando o detector, o feixe é mais uniforme, mas a intensidade cai aquém das sensibilidades dos radiômetros. Assim seria necessário calibrar os radiômetros usando uma fonte adequada e depois transferir a calibração usando a Eq. (4.13). Mas este procedimento tem pouco valor prático, pois, antecipando os resultados das respostas espaciais destes radiômetros, suas características direcionais se afastam demasiadamente das co-senoidais, resultando erros muito superiores aos de desajustes dos espectros de ação, que seriam corrigidos pela calibração espectral. Assim, buscando somente evidenciar os erros espaciais dos radiômetros quando comparados a ER, foi escolhido o procedimento seguinte.

O ponto três na superfície elíptica (FIG. 5.5) foi escolhido como referência de comparações de R1 e R2 nas fontes halógenas. A escolha deste 
ponto se justifica por estar numa região cujas irradiâncias atingem os valores mais elevados.

$\mathrm{Na}$ superfície efetiva retangular da Fig. 5.2 (das fontes que usam lâmpadas fluorescentes), o ponto número dez foi escolhido. Também neste caso a escolha se justifica por ser uma região cujas irradiâncias atingem os valores mais elevados.

Expressando na forma vetorial, os valores medidos por $E R\left(E_{D I N}\right)$ na fonte $F 1$ (noutras fontes o procedimento é similar) são $E_{D I N}=\left[E_{1}, E_{2}, \cdots E_{18}\right]$ e os valores medidos por $R 1$ são $R=\left[R_{1}, R_{2}, R_{3, \ldots} R_{18}\right]$. O vetor $R$ foi multiplicado por uma constante (a) tal que $E_{10}-a \cdot R_{10}=0$. Os valores resultantes são: $a \cdot R 1=R 1 C$. Valores de R1C são agora expressos em irradiâncias eficazes $\mu\left(\mathrm{W} / \mathrm{cm}^{2}\right)$. Caso $\mathrm{R} 1$ fosse calibrado usando uma fonte uniforme, um fator de calibração $(b)$, resultando $b \cdot R$, poderia ser diferente de (a). Assim este procedimento deve ser entendido como um deslocamento de todos os valores de $\mathrm{R} 1$ quando calibrados, isto é, $b \cdot \mathrm{R}$. Mas, com o procedimento usado, nos pontos escolhidos o erro torna-se nulo. Nos demais pontos as diferenças entre $E_{D I N}$ e os radiômetros ensaiados são compostas majoritariamente por desvios das suas responsividades espaciais, e as diferenças são relativas ao ponto onde o erro é nulo, facilitando a análise de suas magnitudes. Note-se que o procedimento adotado exclui diferenças dos espectros de ação de $\mathrm{R} 1$ e $\mathrm{R} 2$ relativas à $E R$, pois forçar erro nulo num ponto pode ser entendido como um processo de calibração espectral segundo a Eq. (4.2), e simultaneamente a compensação do erro espacial de R1.

O espectro de uma fonte halógena é mantido em toda superfície efetiva. Entretanto, nas unidades dotadas de fontes fluorescentes, por serem constituídas por um arranjo de lâmpadas azuis e brancas, o espectro muda em cada ponto em suas superfícies efetivas. Contudo as variações verificadas não são pronunciadas, conforme mostra 0 gráfico na FIG. 5.8, onde os espectros relativos de F2 nos pontos um e dez são apresentados. 


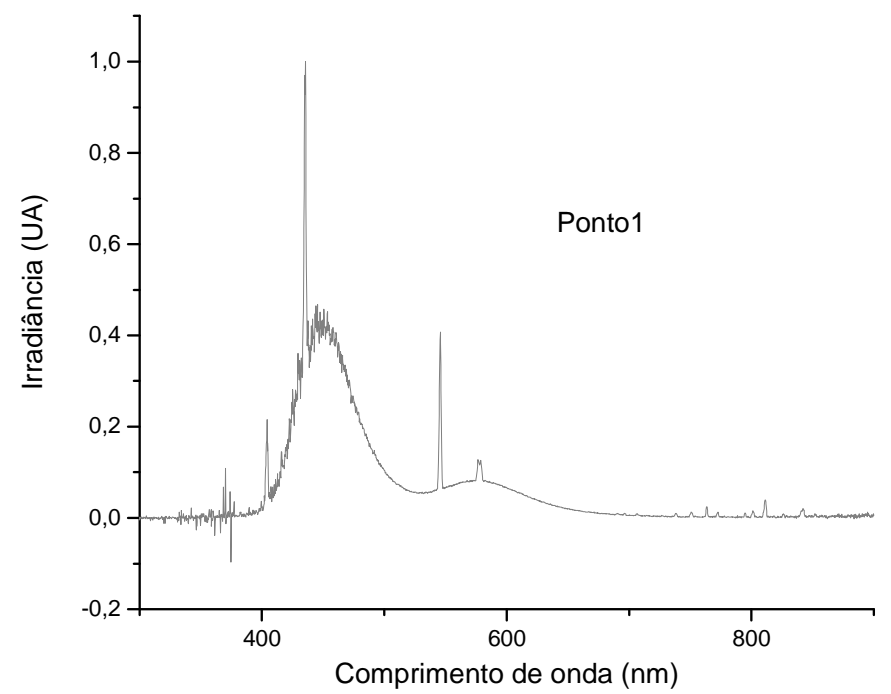

(a)

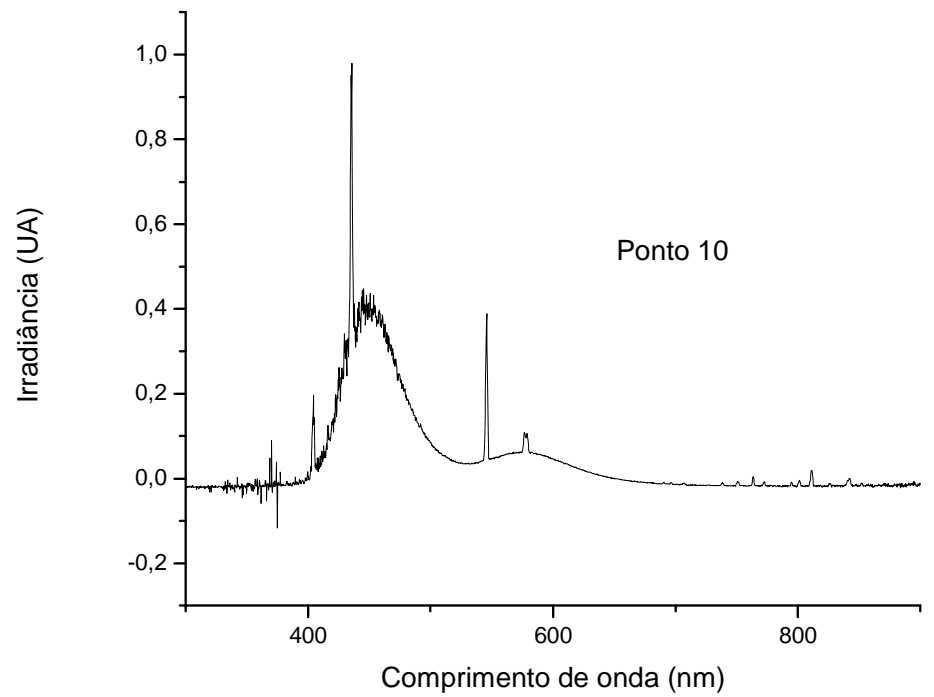

(b)

FIGURA 5.8 - Espectros relativos de F2: a) ponto (1) e b) ponto (10) da sua superfície efetiva. 


\section{RESULTADOS}

A literatura relacionada à fototerapia no tratamento da icterícia neonatal tem demonstrado que irradiâncias eficazes medidas com radiômetros comerciais apresentam diferenças superiores a 100\%, e tem-se conjeturado que tais diferenças são oriundas da diversidade de responsividades espectrais dos radiômetros. Contudo, este Capítulo apresenta resultados mostrando que, embora tais diferenças possam ser elevadas, outros fatores devem ser considerados além da resposta espectral. Dentre eles, a responsividade espacial é um fator determinante e, uma vez que tem sido negligenciado na literatura acima referida, pode ter conduzido muitos pesquisadores a interpretações errôneas quando dois ou mais radiômetros são comparados. Embora este tópico (responsividade espacial) aborde apenas a caracterização dos radiômetros usados, mostrando a inadequação de comparações diretas entre radiômetros quando o objetivo é conhecer erros em medições decorrentes de desajustes das responsividades espectrais. Na seqüência são apresentadas as irradiâncias espectrais das fontes estudadas. Usando os espectros obtidos, as características (C) dos radiômetros ensaiados são apresentadas, e são valores constantes que relacionam cada radiômetro a cada fonte. Usando as características dos radiômetros, é mostrado que o erro resultante do desajuste das responsividades espectrais dos radiômetros ensaiados, isoladamente, não justifica diferenças da ordem de $100 \%$. O termo "isoladamente" deve ser salientado: o método usado para comparar radiômetros independe de suas responsividades espaciais. Usando o mesmo método também é apresentado o erro de medição resultante do uso de uma curva de ação gaussiana que é uma aproximação do espectro de ação DIN.

$\mathrm{Na}$ seqüência este Capítulo apresenta os valores das irradiâncias eficazes medidas em diversas regiões nas superfícies das quatro fontes estudadas onde a radiação é disponível ao tratamento (superfície efetiva), usando o espectro-radiômetro ER como referência e os dois radiômetros ensaiados. Usando os valores medidos, as irradiâncias eficazes médias de cada fonte são calculadas e comparadas. Os resultados obtidos mostram que, nas fontes ensaiadas, as elevadas variações espaciais da radiação óptica nas suas superfícies efetivas e até o método de cálculo da irradiância média nas superfícies 
são fatores importantes na quantificação das irradiâncias eficazes médias disponíveis ao tratamento, apresentando variações superiores a $100 \%$.

\subsection{Responsividades espaciais dos radiômetros}

O gráfico na FIG. 6.1 apresenta as responsividades espaciais dos detectores ensaiados R1 e R2 e do espectro-radiômetro ER, em coordenadas polares.

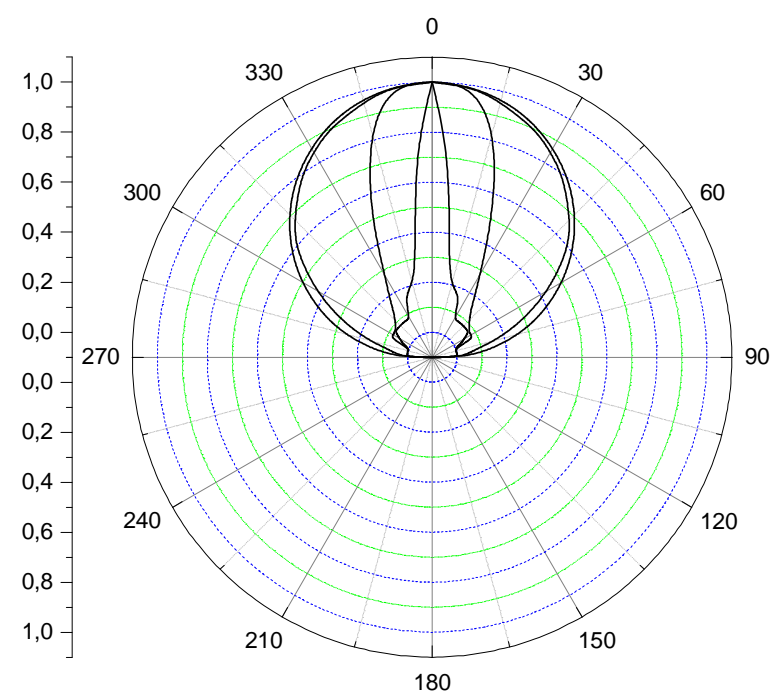

FIGURA 6.1 - Diagrama polar das responsividades espaciais dos detectores ensaiados. 0 circulo externo corresponde à resposta ideal co-senoidal. O traço mais próximo ao externo corresponde ao espectro-radiômetro ER e sucessivamente R1 e R2.

O gráfico na FIG. 6.2 mostra os erros co-seno (definição no Capítulo 4), seguindo a equação: $E_{C}(\%)=\left\{\left[I_{D}(\theta) / \cos (\theta)\right]-1\right\} \cdot 100$, onde $I_{D}$ é o sinal do detector, e $-\pi / 2 \leq \phi \leq \pi / 2$ é o ângulo de incidência da radiação óptica na superfície do detector. 


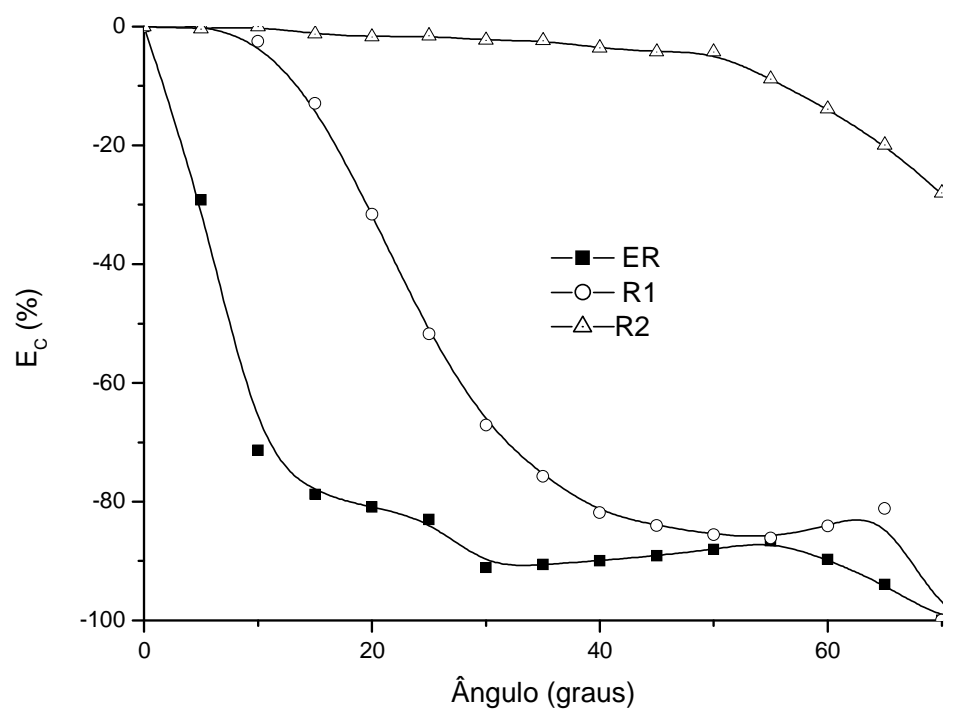

FIGURA 6.2 - Erro co-seno dos detectores ER, R1 e R2 ensaiados.

Os erros co-seno encontrados nos radiômetros R1 e R2 (FIG. 6.2) são demasiadamente elevados para comparações diretas entre radiômetros usando as fontes ensaiadas (pois as fontes são estendidas) quando o objetivo é estudar desajustes nas responsividades espectrais dos radiômetros. Assim, na seqüência são apresentadas as caracterizações das fontes e radiômetros usando o método descrito no Capítulo 4. O método possibilita estudar os desajustes nas respostas espectrais de radiômetros, mesmo quando suas respostas espaciais são inadequadas.

\subsection{Irradiâncias espectrais das fontes}

As irradiâncias espectrais em unidades arbitrárias (UA) das fontes ensaiadas $\mathrm{F} 1, \mathrm{~F} 2$, $\mathrm{H} 1$ e H2, medidas com o espectro-radiômetro $\mathrm{ER}$ nas regiões dez (F1 e F2) e três ( $\mathrm{H} 1$ e H2) das FIG. 5.2 e FIG. 5.5 (respectivamente), dentro das superfícies efetivas, são apresentadas nas FIG. 6.3, FIG. 6.4, FIG. 6.5 e FIG. 6.6 . 


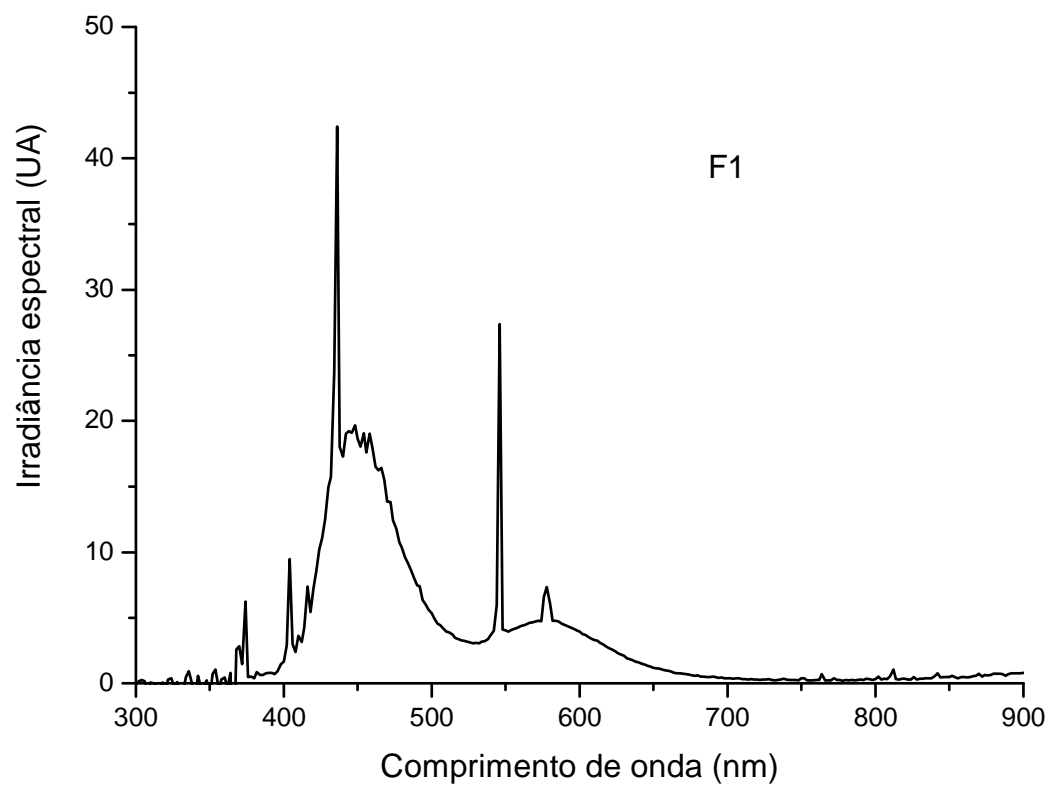

FIGURA 6.3 - Irradiância espectral da fonte F1 medida no ponto dez da superfície definida na FIG. 5.2 .

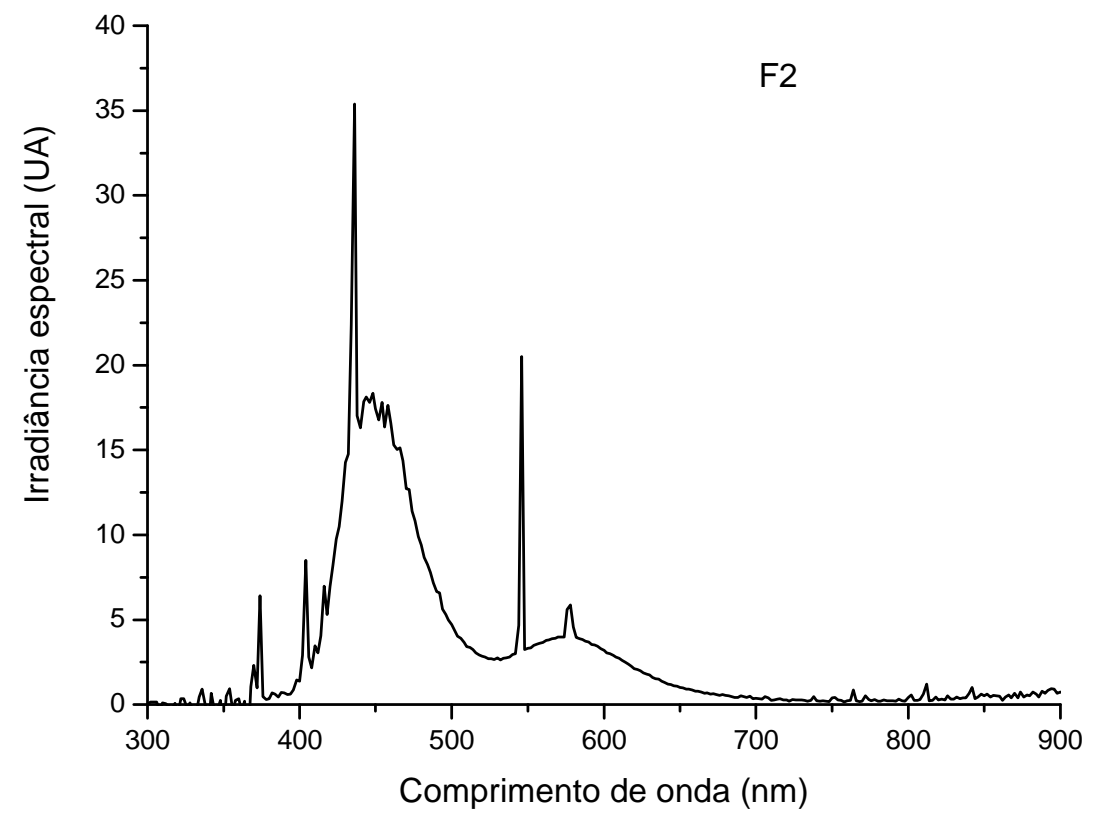

FIGURA 6.4 - Irradiância espectral da fonte F2 medida no ponto dez da superfície definida na FIG. 5.2. 


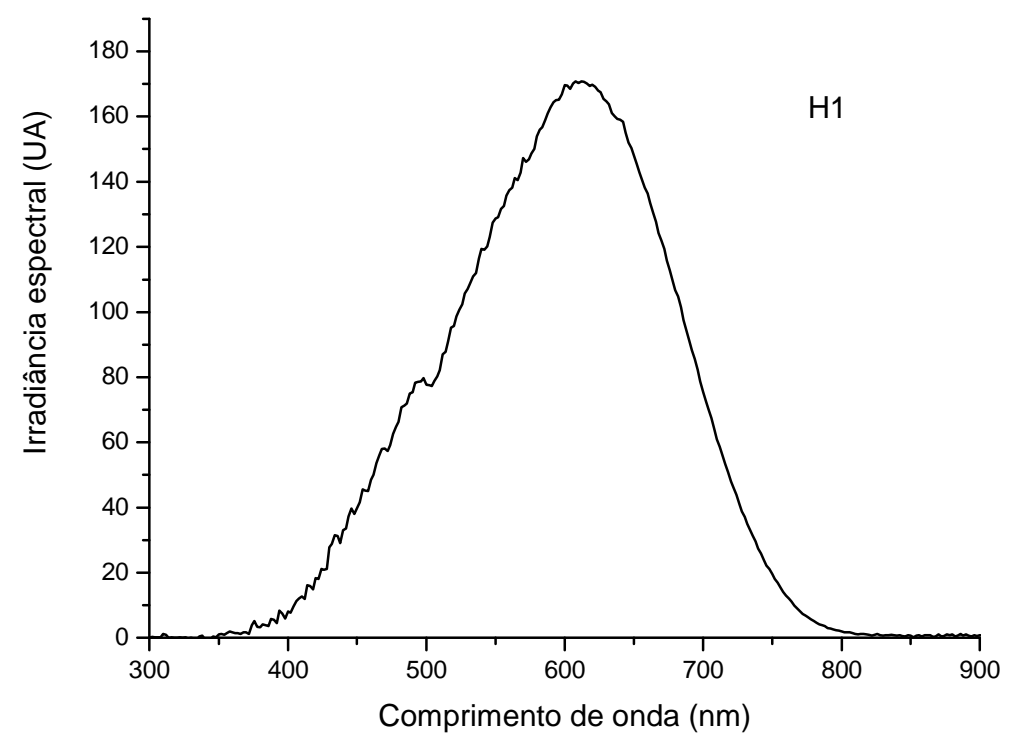

FIGURA 6.5 - Irradiância espectral da fonte H1 medida no ponto três da superfície definida na FIG. 5.5.

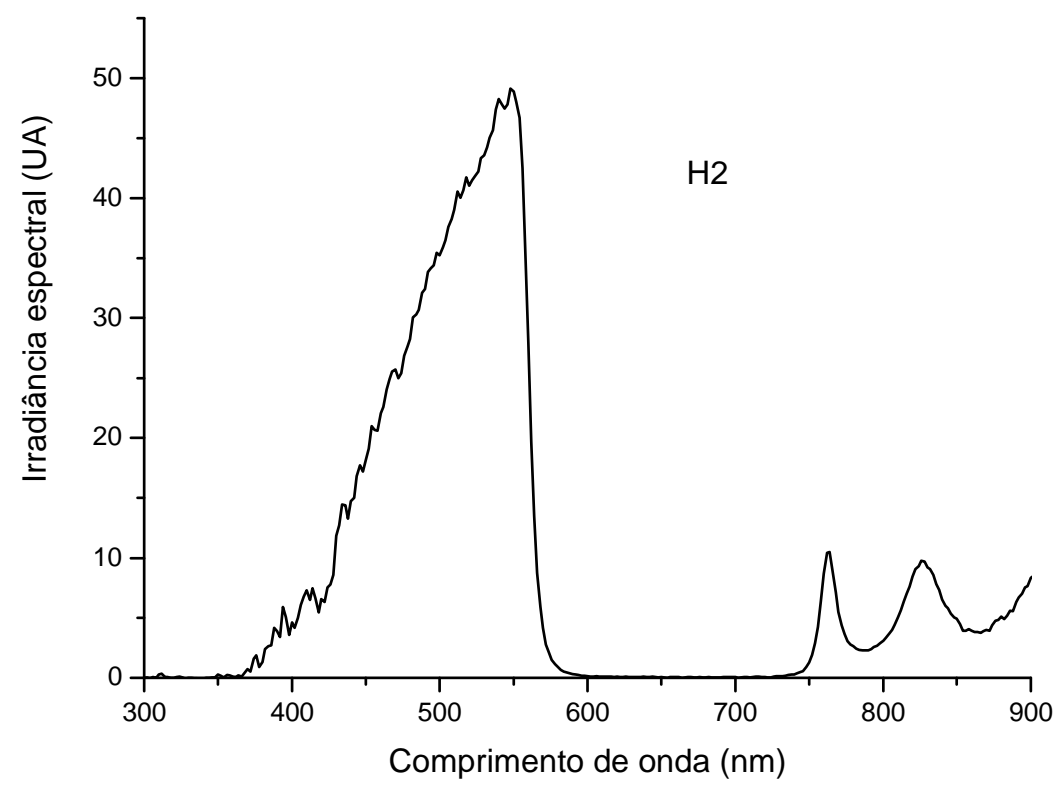

FIGURA 6.6 - Irradiância espectral da fonte H2 medida no ponto três da superfície definida na FIG. 5.5 . 


\subsection{Responsividade espectral do detector}

As irradiâncias eficazes calculadas partindo das irradiâncias espectrais medidas nas regiões escolhidas nas superfícies efetivas das fontes F1, F2, H1 e H2 (FIG. 6.3 a FIG. 6.6), são mostradas na TAB. 6.1. O cálculo foi efetuado seguindo as equações

$$
E_{D I N}=\int_{\lambda 1}^{\lambda 2} S_{D I N} \cdot E(\lambda) d \lambda
$$

e

$$
Q_{e f}=\int_{\lambda 1}^{\lambda 2} S_{a}(\lambda) \cdot E(\lambda) d \lambda
$$

onde $S_{D I N}(\lambda)$ é o espectro de ação DIN (definido no Capítulo 5 ), $S_{a}(\lambda)$ são as curvas de ação aproximadas dos radiômetros R1 e R2, mostradas na FIG. 5.7, e uma gaussiana $\mathrm{G}(460,26) \mathrm{nm}$. Na TAB. 6.1 também são mostrados os valores das irradiâncias (E) de cada fonte calculada na faixa entre $300 \mathrm{~nm}$ a $900 \mathrm{~nm}$. Os limites das integrais são $300 \mathrm{~nm}$ e $900 \mathrm{~nm}$.

TABELA 6.1 - Irradiâncias eficazes calculadas em unidades arbitrárias (UA), das fontes F1, F2, H1 e H2, partindo das irradiâncias espectrais medidas em regiões escolhidas nas superfícies efetivas de cada fonte, e dos espectros de ação de R1, R2, gaussiana G e DIN (usada no espectroradiômetro ER). Na última coluna $E$ é a irradiância de cada fonte na faixa entre $300 \mathrm{~nm}$ a $900 \mathrm{~nm}$.

\begin{tabular}{cccccc}
\hline Espectro de ação & DIN & G & R1 & R2 & E \\
\hline $\begin{array}{c}\text { Unidade de } \\
\text { fototerapia }\end{array}$ & $\begin{array}{c}\text { Irradiância } \\
\text { eficaz } \\
\text { (UA) }\end{array}$ & $\begin{array}{c}\text { Irradiância } \\
\text { eficaz } \\
\text { (UA) }\end{array}$ & $\begin{array}{c}\text { Irradiância } \\
\text { eficaz } \\
\text { (UA) }\end{array}$ & $\begin{array}{c}\text { Irradiância } \\
\text { eficaz }\end{array}$ & $\begin{array}{c}\text { Irradiância } \\
\text { F1 }\end{array}$ \\
868 & 913 & 1100 & 598 & $($ UA) \\
F2 & 799 & 842 & 1012 & 552 & 1986 \\
H1 & 3050 & 3247 & 4723 & 2171 & 33519 \\
H2 & 1350 & 1436 & 1980 & 961 & 5500 \\
\hline
\end{tabular}


Partindo dos valores constantes na TAB. 6.1, foram calculados os valores das características dos radiômetros $\mathrm{R} 1$ e $\mathrm{R} 2$, e dos espectros de ação DIN e da gaussiana G (TAB. 6.2), seguindo as Eq. (4.8) e Eq. (4.9).

TABELA 6.2 - Valores das características dos radiômetros $\mathrm{R} 1$ e R2, e dos espectros de ação DIN e $\mathrm{G}$ para as fontes ensaiadas $\mathrm{F} 1, \mathrm{~F} 2, \mathrm{H} 1$ e $\mathrm{H} 2$.

\begin{tabular}{ccccc}
\hline $\begin{array}{c}\text { Unidade de } \\
\text { fototerapia }\end{array}$ & $\mathrm{C}_{\mathrm{p}}(\mathrm{DIN})$ & $\mathrm{C}_{\mathrm{a}}(\mathrm{G})$ & $\mathrm{C}_{\mathrm{a}}(\mathrm{R} 1)$ & $\mathrm{C}_{\mathrm{a}}(\mathrm{R} 2)$ \\
$\mathrm{F} 1$ & 0,4366 & 0,4597 & 0,5537 & 0,3014 \\
$\mathrm{~F} 2$ & 0,4486 & 0,4724 & 0,5677 & 0,3098 \\
$\mathrm{H} 1$ & 0,0910 & 0,0969 & 0,1409 & 0,0648 \\
$\mathrm{H} 2$ & 0,2451 & 0,2610 & 0,3599 & 0,1748 \\
\hline
\end{tabular}

Usando as características dos radiômetros (TAB. 6.2) é possível saber o erro resultante do uso de uma gaussiana $\mathrm{G}(460,26) \mathrm{nm}$, como uma aproximação do espectro de ação DIN. Ou seja, usando a Eq. (4.11), a irradiância eficaz medida com um radiômetro (ou espectro-radiômetro) construído com a gaussiana G difere da irradiância eficaz medida com um radiômetro construído com 0 espectro de ação DIN, e o erro é:

$$
\operatorname{Erro}(\%)=\left[\frac{C_{a}}{C_{p}}-1\right] \cdot 100
$$

O erro na Eq. (6.1) depende da fonte: o erro máximo, dentre as fontes ensaiadas, é igual a 6,5\% e ocorre para ambas as fontes $\mathrm{H} 1$ e $\mathrm{H} 2$. Para as demais fontes o erro é igual a 5,3\%, quando medidas por um radiômetro usando a curva de ação $\mathrm{G}(460,26)$.

Comparando as irradiâncias medidas usando os espectros de ação de R1 e $\mathrm{R} 2$ relativo ao espectro DIN, os erros encontrados são entre $-31 \%$ ( $R 2$ medindo $\mathrm{F} 1$ ou $\mathrm{F} 2$ ) e $55 \%$ (R1 medindo $\mathrm{H} 1$ ).

Usando as características dos radiômetros (TAB. 6.2) também é possível saber o erro resultante da medição de uma fonte com um radiômetro calibrado noutra fonte. Ou seja, usando a Eq. (4.14), o erro é: 


$$
\operatorname{Erro}(\%)=\left[\frac{C_{p 1} \cdot C_{a 2}}{C_{p 2} \cdot C_{a 1}}-1\right] \cdot 100
$$

O erro na Eq. (6.2) depende das fontes. O erro máximo, dentre as fontes e radiômetros ensaiados, ocorre quando o detector $\mathrm{R} 1$ é calibrado com a fonte $\mathrm{F} 2 \mathrm{e}$ mede a fonte $\mathrm{H} 1$ (22\%). Quando as fontes $\mathrm{H} 1$ e H2 são usadas para calibrar R1, como um exemplo, e mede F1 ou F2, o erro máximo é - 4\%. Considerando todas as possibilidades (de escolha de fonte para a calibração e de radiômetros), os erros máximos encontrados variaram entre $-4 \%$ a $22 \%$.

\subsection{Irradiância eficaz média das fontes}

As tabelas TAB. A1 a TAB. A12 no ANEXO A apresentam os valores das irradiâncias eficazes medidas nas superfícies efetivas das unidades de fototerapia ensaiadas F1, F2 (18 regiões, conforme a FIG. 5.2), H1 e H2 (24 regiões, conforme mostra a FIG. 5.5), usando o espectro-radiômetro ER e os radiômetros $\mathrm{R} 1$ e $\mathrm{R} 2$. Os valores médios calculados das irradiâncias eficazes nas superfícies efetivas das fontes são mostrados na TAB. 6.3. As irradiâncias eficazes médias de $\mathrm{H} 1$ e $\mathrm{H} 2$ foram calculadas usando dois métodos: i) a média aritmética das irradiâncias eficazes medidas nas 24 regiões e; ii) a média aritmética das potências coletadas pelas 24 regiões (descrito no Capítulo 5).

TABELA 6.3 - Valores das irradiâncias eficazes médias das fontes F1, F2, H1 e H2 calculadas usando os valores das irradiâncias eficazes medidas nas superfícies das fontes (TAB. A1 a A12, ANEXO A). As irradiâncias eficazes médias de $\mathrm{H} 1$ e $\mathrm{H} 2$ foram calculadas usando dois métodos: i) a média aritmética das irradiâncias eficazes medidas nas 24 regiões e; ii) a média aritmética das potências coletadas nas 24 regiões(entre parênteses).

\begin{tabular}{|c|c|c|c|}
\hline Radiômetro & ER & $\mathrm{R} 1$ & $\mathrm{R} 2$ \\
\hline $\begin{array}{l}\text { Unidade de } \\
\text { fototerapia }\end{array}$ & $\begin{array}{c}\text { Irradiância } \\
\text { eficaz } \\
\left(\mu \mathrm{W} / \mathrm{cm}^{2}\right)\end{array}$ & $\begin{array}{c}\text { Irradiância } \\
\text { espectral } \\
\text { eficaz } \\
\left(\mu \mathrm{W} / \mathrm{cm}^{2} . \mathrm{nm}\right)\end{array}$ & $\begin{array}{c}\text { Irradiância } \\
\text { espectral } \\
\text { eficaz } \\
\left(\mu \mathrm{W} / \mathrm{cm}^{2} . \mathrm{nm}\right)\end{array}$ \\
\hline $\mathrm{F} 1$ & 982 & 10,1 & 8,7 \\
\hline $\mathrm{F} 2$ & $\begin{array}{l}1159 \\
1215\end{array}$ & $\begin{array}{c}11,2 \\
6.7\end{array}$ & $\begin{array}{l}10,7 \\
3,4\end{array}$ \\
\hline $\mathrm{H} 1$ & $\begin{array}{l}(848) \\
781\end{array}$ & $(9,8)$ & $(4,4)$ \\
\hline $\mathrm{H} 2$ & (577) & $\begin{array}{c}4,1 \\
(5,7)\end{array}$ & $\begin{array}{c}1,8 \\
(2,3)\end{array}$ \\
\hline
\end{tabular}


Na TAB. 6.3 pode ser verificado que as irradiâncias médias eficazes calculadas via médias aritméticas das irradiâncias medidas nas 24 regiões de $\mathrm{H} 1$ e H2 são superiores às derivadas das potências coletadas em cada região da superfície efetiva. Portanto, para as fontes $\mathrm{H} 1$ e $\mathrm{H} 2$, a média aritmética das irradiâncias, medidas nas superfícies efetivas, superestima a irradiância média. Comparando os dois métodos, considerando como referência os valores das irradiâncias eficazes médias derivadas das potências coletadas, e somente considerando as irradiâncias medidas por ER, o erro máximo é de $43 \%$ e ocorre quando ER mede a fonte $\mathrm{H} 1\left(848 \mu \mathrm{W} / \mathrm{cm}^{2}\right.$ e $1216 \mu \mathrm{W} / \mathrm{cm}^{2}$ respectivamente).

Na TAB. 6.3 também pode ser verificado que as irradiâncias espectrais eficazes médias de $\mathrm{H} 1$ e $\mathrm{H} 2$ medidas por $\mathrm{R} 1$ são superiores às medidas por R2. O maior desvio relativo entre R1 e R2 ocorre quando irradiâncias espectrais eficazes médias de $\mathrm{H} 2$ são calculadas segundo a média das potências coletadas $\left(4,1 \mu \mathrm{W} / \mathrm{cm}^{2} . \mathrm{nm}\right.$ e $1,8 \mu \mathrm{W} / \mathrm{cm}^{2}$.nm, respectivamente). Tomando arbitrariamente R2 como referência, o erro é $128 \%$.

Os valores das irradiâncias espectrais da TAB. 6.3 são transcritos para a TAB. 6.4, onde os valores das irradiâncias eficazes medidos com o espectroradiômetro de referencia (ER) são convertidos em irradiâncias espectrais, usado a largura FWHM do espectro de ação DIN (56nm). Comparando as irradiâncias espectrais eficazes médias estimadas via ER, R1 e R2 para cada fonte, o erro máximo é igual a -83,4\% (ER é 6 vezes superior a R2), e ocorre quando R2 mede a fonte $\mathrm{H} 2$, quando comparado à obtida via $E R$, quando as irradiâncias são as médias aritméticas das irradiâncias medidas nas regiões das superfícies. Portando, tomando como referência o espetro-radiômetro ER com espectro de ação DIN e sua largura FWHM para quantificar a irradiância espectral média, o erro máximo encontrado é de $-83,4 \%$, quando R2 é usado. 
TABELA 6.4 - Valores das irradiâncias espectrais eficazes médias das fontes F1, F2, H1 e H2 calculadas usando os valores das irradiâncias eficazes medidas nas superfícies das fontes (TAB. A1 a A12, ANEXO A). As irradiâncias eficazes médias de $\mathrm{H} 1$ e H2 foram calculadas usando dois critérios: i) a média aritmética das irradiâncias eficazes medidas nas 24 regiões (entre parênteses) e; ii) a média aritmética das potências coletadas pelas 24 regiões. Valores medidos com ER (espectro-radiômetro) foram convertidos para irradiâncias espectrais usando a largura FWHM do espectro de ação DIN (56nm).

\begin{tabular}{|c|c|c|c|}
\hline Radiômetro & ER & R1 & $\mathrm{R} 2$ \\
\hline $\begin{array}{l}\text { Unidade de } \\
\text { fototerapia }\end{array}$ & $\begin{array}{c}\text { Irradiância } \\
\text { espectral } \\
\text { eficaz } \\
\left(\mu \mathrm{W} / \mathrm{cm}^{2} . \mathrm{nm}\right)\end{array}$ & $\begin{array}{c}\text { Irradiância } \\
\text { espectral } \\
\text { eficaz } \\
\left(\mu \mathrm{W} / \mathrm{cm}^{2} . \mathrm{nm}\right)\end{array}$ & $\begin{array}{c}\text { Irradiância } \\
\text { espectral } \\
\text { eficaz } \\
\left(\mu \mathrm{W} / \mathrm{cm}^{2} . \mathrm{nm}\right)\end{array}$ \\
\hline F1 & 17,5 & 10,1 & 8,7 \\
\hline $\mathrm{F} 2$ & $\begin{array}{l}20,7 \\
15,1\end{array}$ & $\begin{array}{c}11,2 \\
6,7\end{array}$ & $\begin{array}{c}10,7 \\
3,4\end{array}$ \\
\hline $\mathrm{H} 1$ & $(21,7)$ & $(9,8)$ & $(4,4)$ \\
\hline $\mathrm{H} 2$ & $\begin{array}{c}10,3 \\
(13,9)\end{array}$ & $\begin{array}{c}4,1 \\
(5,7)\end{array}$ & $\begin{array}{c}1,8 \\
(2,3)\end{array}$ \\
\hline
\end{tabular}

\subsection{Estimativas dos erros espaciais}

Os valores das irradiâncias espectrais eficazes medidas com os radiômetros $R 1$ e $R 2$, nas 18 regiões das superfícies efetivas das fontes $F 1$ e F2 e nas 24 regiões das fontes $\mathrm{H} 1$ e $\mathrm{H} 2$ (TAB. $\mathrm{A} 1$ a $\mathrm{A} 12)$ são apresentados nas TAB. B1 a B4 do ANEXO B.

Para facilitar a interpretação das TAB. B1 a TAB. B4, como um exemplo para as fontes com lâmpadas fluorescentes (F1 e F2), os valores dos erros das irradiâncias eficazes medidos com R2 na superfície da fonte $F 1$, ajustados para erro nulo na região dez (usando ER como referência), são apresentados no gráfico da FIG. 6.7 onde pode ser notado que o erro é nulo na região dez. Noutras regiões o erro é predominantemente negativo, e o erro máximo é $-26,4 \%$.

$\mathrm{Na}$ FIG. 6.7 pode ser verificado que o erro aumenta nas regiões periféricas. $\mathrm{Na} \mathrm{TAB}$. B1 pode ser observado que, na mesma fonte, o erro máximo de $\mathrm{R} 1$ relativo a ER ocorre no ponto um e é $-24,4 \%$. 
Para a fonte F2 (TAB. B2) o erro máximo é -28,9\% (R2 no ponto 13).

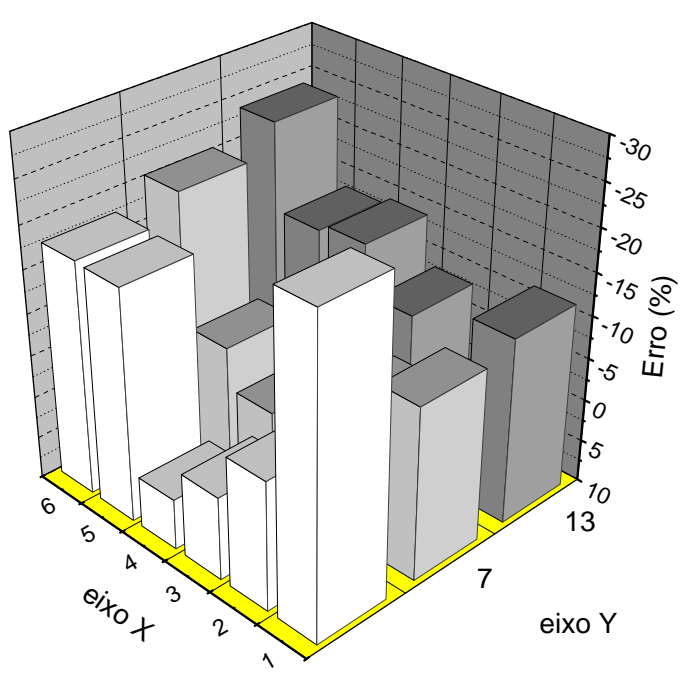

FIGURA 6.7 - Gráfico tridimensional dos erros encontrados quando R2 é ajustado para erro nulo na região dez da fonte F1 (FIG. 5.2).

Os valores dos erros das irradiâncias eficazes medidos com R2, ajustados para erro nulo na região três da superfície da fonte H1 (usando ER como referência) são apresentados no Quadro (B) da FIG. 6.8, onde pode ser notado que o erro é nulo na região três. Noutras regiões onde a irradiância é elevada e apresenta não uniformidades, o erro é predominantemente positivo, e em regiões onde as intensidades são baixas, o erro é predominantemente negativo. Os erros máximos são $77,6 \%$ e $-77,7 \%$ (regiões seis e sete, respectivamente). Na mesma fonte, o erro máximo para R1 é $41,6 \%$ no ponto 17 (TAB. B3).

Para a fonte H2, os erros máximos ocorrem com R2 e são $113,1 \%$ e $-100 \%$ nos pontos um e seis respectivamente (TAB. B4).

Inspecionando as TAB. B3 e TAB. B4, pode ser verificado que os erros máximos de R2 são significativamente superiores aos observados com R1 para ambas as fontes $\mathrm{H} 1 \mathrm{e} \mathrm{H} 2$. 


\begin{tabular}{|c|c|c|c|c|c|c|c|c|}
\hline \multicolumn{10}{|c|}{ Quadro A } \\
\hline & 7 & & & 13 & & & 19 & \\
\hline & & & & 14 & & & & \\
\hline & & 8 & 9 & 15 & 21 & 20 & & \\
\hline 1 & 2 & 3 & & & & 4 & 5 & 6 \\
\hline & & 23 & 22 & 16 & 10 & 11 & & \\
\hline & & & & 17 & & & & \\
\hline & 24 & & & 18 & & & 12 & \\
\hline
\end{tabular}

\begin{tabular}{|c|c|c|c|c|c|c|c|c|}
\hline \multicolumn{10}{|c|}{ Quadro B } \\
\multicolumn{10}{|c|}{$\left(\frac{R 2 C-E_{\text {DIN }}}{E_{\text {IIN }}}\right) \cdot 100$} \\
\hline & 77,6 & & & $-15,6$ & & & -54 & \\
\hline & & & & 10,6 & & & & \\
\hline & & 37,4 & 37,4 & 19,6 & 27 & $-3,7$ & & \\
\hline 31,8 & 0,4 & 0 & & & & 7,6 & $-4,3$ & $-77,7$ \\
\hline & & 38,8 & 24,4 & $-0,9$ & $-8,4$ & $-12,6$ & & \\
\hline & & & & $-2,6$ & & & & \\
\hline & 40,1 & & & $-18,8$ & & & $-58,1$ & \\
\hline
\end{tabular}

FIGURA 6.8 - O quadro (B) mostra os erros encontrados quando R2 é ajustado para erro nulo (contra ER) na região três da fonte $\mathrm{H} 1$, seguindo o esquema de apresentação das regiões conforme mostra o Quadro (A). 


\section{DISCUSSÕES}

A padronização de um método de quantificação da irradiância eficaz na superfície efetiva é de interesse: i) na comparação de estudos sobre a eficácia do tratamento fototerápico; ii) na área clínica, para o estabelecimento de doses previsíveis e eficazes e; iii) aos fabricantes de unidades de irradiação. Em todas estas áreas de interesse, o radiômetro ou espectro-radiômetro é um fator comum. Contudo, os resultados aqui obtidos mostram que somente padronizar radiômetros ou as quantidades que eles medem não atende aos interesses acima apontados. Assim, em adição ao processo de padronização de instrumentos destinados a medir a "dose" (irradiância eficaz), deveria ser considerada a padronização dos métodos de cálculo da irradiância eficaz média na superfície efetiva, onde a radiação óptica é disponível.

Retornando o foco ao radiômetro, e questionando: qual é a conseqüência de um erro de $100 \%$ na quantificação da dose? Esta questão é discutida no final deste Capítulo, depois de discutidos os principais fatores que resultam em erros nas medições e no cálculo da irradiância eficaz média.

\subsection{Medição da irradiância eficaz}

Embora as medições radiométricas sejam aplicadas na fototerapia há mais de 50 anos, não há na literatura relacionada um estudo sistemático sobre radiometria na fototerapia. Como um resultado, os radiômetros desenhados para a fototerapia medem quantidades diferentes (Vreman et al., 2004). Outros expressam unidades diferentes (AAP, 2004). Na seqüência tais tópicos são focos de discussões.

\subsubsection{Quantidades e unidades}

Definições padronizadas para termos radiométricos e dosimétricos e unidades nas áreas da ciência de óptica, foto-biologia e fotoquímica tem sido desenvolvidas de forma consensual na Commission International de l'Eclairage (CIE), em concordância com o Sistema Internacional de unidades (Système 
International - SI). Os termos radiométricos fundamentais mais usados são: comprimento de onda $(m)$; potência radiante $(W)$; energia radiante $(J)$; exposição radiante $\left(\mathrm{J} / \mathrm{m}^{2}\right)$ e; irradiância $\left(\mathrm{W} / \mathrm{m}^{2}\right)$. O termo irradiância espectral também é usado (Sliney, 2007), mas significa a irradiância em cada unidade elementar de comprimento de onda.

A propagação da luz na pele tem sido largamente medida e modelada. A faixa entre $400 \mathrm{~nm}$ e $550 \mathrm{~nm}$, tem sido mostrada como um modelo adequado da pele que é um meio multicamadas, difuso e altamente espalhador, cuja direção de espalhamento é preferencialmente na direção de incidência da radiação. Embora a penetração possa ser maior em comprimentos de onda mais elevados, até 550nm pouco da radiação penetra mais de $1 \mathrm{~mm}$ (Dicken et al.., 2000). Assim, a irradiância quantifica adequadamente a taxa de exposição de uma superfície à radiação óptica. Quando o espectro da fonte é ponderado por um espectro de ação, tal quantidade é comumente chamada "taxa de dose efetiva" (aqui denominada irradiância eficaz), e quando integrada no tempo, "dose efetiva" (Sliney, 2007). Portanto, a quantidade irradiância eficaz é adequada e suficiente.

Conforme exposto no Capítulo 4, apesar desnecessário, tem sido comum expressar a irradiância eficaz numa faixa espectral $\Delta \lambda$, usando erroneamente a unidade de irradiância espectral. Uma vez que não há definição única para a faixa referida, talvez este seja um dos maiores geradores de incertezas. Contudo é comum expressar a largura FWHM de um filtro óptico. Usando este critério, isto é, dividindo a irradiância eficaz medida com ER pela largura FWHM do espectro de ação DIN (56nm), e comparando os resultados das irradiâncias espectrais eficazes médias medidas com R1 e R2, para as fonte $F 1$, F2, $\mathrm{H} 1$ e H2, o erro máximo encontrado é igual a $-83,4 \%$ (ER é 6 vezes superior a R2), e ocorre quando R2 mede a fonte $H 2$, quando comparado à obtida via $E R$, quando as irradiâncias são as médias aritméticas das irradiâncias medidas nas regiões das superfícies (TAB. 6.4). No entanto, este resultado é limitado (pois não há espectro de ação padrão de definição única da faixa espectral $\Delta \lambda$ ). Mas associado ao fato de que desajustes dos espectros de ação não resultam erros elevados, este resultado sugere que as responsividades espaciais também são importantes. 


\subsubsection{Calibração}

A radiometria de banda larga na faixa ultravioleta do espectro é freqüentemente usada nas áreas industrial, médica e ambiental. Tais radiômetros têm sido calibrados seguindo os mesmos princípios da fotometria. Contudo, embora os fabricantes declarem incertezas na ordem de $\pm 5 \%$ a $\pm 10 \%$, diferenças na ordem de 30\% têm sido observadas (Xu e Huang, 2003). Buscando resolver esta questão, vários métodos de calibração e de avaliação de incertezas têm sido propostos nos últimos anos (Xu e Huang, 2003; Envalla e Karha, 2006).

Os fundamentos da radiometria de banda larga, bem como os últimos desenvolvimentos nesta área, são aplicados no presente trabalho à radiometria de equipamentos de fototerapia de neonatos.

Antes de prosseguir, convém enfatizar que a calibração de um radiômetro requer um detector com responsividade espectral padrão. No entanto, na literatura relacionada à fototerapia de neonatos não há um espectro de ação padrão. A despeito deste fato, fabricantes de radiômetros específicos para a fototerapia de neonatos têm desenhado suas responsividades na faixa azul do espectro, com formas e larguras variadas, "calibrados para fontes específicas" (Vreman, 2004): desde o princípio há uma vasta diversidade de espectros de ação nos radiômetros usados nos estudos clínicos (e.g, Hammerman et al.., 1981), se estendendo até os dias atuais (Vreman, 2004; AAP, 2004). Mas está fora do escopo do presente trabalho propor um espectro de ação padrão que expresse o desempenho de uma fonte de luz no tratamento da icterícia neonatal e ou uma relação dose-resposta. $O$ assunto é extenso e ainda não há evidências suficientes para responder esta questão. Neste trabalho foi usado o espectro de ação sugerida pela norma DIN 5031-10 (1996) para exemplificar a aplicação do método aqui usado. Mas os fundamentos da radiometria podem ser usados para transferir a calibração (e valores medidos) de um radiômetro usando uma curva DIN para outra que venha a ser adotada como padrão, de forma similar à transferência de calibração de uma fonte para outra com espectros diferentes. Este assunto é discutido mais adiante. 
Ainda, antes de prosseguir, convém ressaltar um resultado importante, relativo às diferenças de responsividades espectrais dos radiômetros ensaiados, quando comparadas entre si e relativas ao espectro de ação DIN.

A TAB. 6.2 mostra que, embora as características dos detectores R1 e R2 sejam significativamente diferentes das características da curva DIN para quaisquer das fontes, depois de calibrados, o desvio máximo estimado que ocorre quando um desses radiômetros é calibrado para uma fonte e mede outra com espectro diferente é de $22 \%$. Portanto, significativamente menor quando comparado aos erros espaciais e de metodologia de medição da irradiância média de uma fonte com foco dirigido.

No presente trabalho um espectro-radiômetro foi calibrado, usando uma fonte calibrada. A fonte dispõe de duas lâmpadas: uma de deutério e outra de tungstênio halógena, calibradas na faixa entre $220 \mathrm{~nm}$ a $1050 \mathrm{~nm}$, rastreados pelo National Institute of Standards and Technology (NIST). A fonte usada (DH2000-CAL, detalhes no Capítulo 5) é especificamente calibrada para o uso com fibras ópticas ou sondas contendo um corretor co-seno. O espectro-radiômetro foi equipado com uma sonda CC-3-UV, que usa um difusor de FTFE com 3,9 mm de diâmetro.

O espectro-radiômetro calibrado foi usado como medidor padrão de trabalho (working standard meter). A incerteza da calibração, declarada pelo fabricante da fonte, é de $\pm 5 \%$. A irradiância eficaz foi calculada usando a irradiância espectral medida com o medidor padrão. A quantidade resultante é aqui usada como referência.

O arranjo utilizado é de baixo custo, e apresenta outras vantagens quando comparado a espectro-radiômetros mais precisos e onerosos, mas quase sempre desenhados para medir a radiância, cujos ângulos de coleção são geralmente pequenos, exigindo o uso de esferas integradoras ou outro tipo de corretor co-senoidal. No arranjo utilizado, a principal vantagem é o fato de a radiação ser guiada ao espectrômetro por fibra óptica, terminando em uma sonda com corretor co-seno com erro de desvio de resposta menor que $10 \%$ até 50 graus (FIG. 6.1 e FIG. 6.2). Assim o arranjo é robusto e permite fácil acesso à superfície efetiva, e associado ao atual baixo custo, pode substituir com 
vantagens os radiômetros comerciais. Melhorar a resposta co-senoidal da sonda e estudar a uniformidade da responsividade espacial do conjunto, explorando a capacidade intrínseca das fibras ópticas e grades de difração na uniformização do feixe luminoso são sugestões de alvos para futuras investigações.

Assim um espectro-radiômetro foi usado nas medições consideradas de referência, para comparações com os radiômetros ensaiados.

Para efetuar comparações entre aos valores medidos com o espectroradiômetro e os radiômetros ensaiados, foi encontrada uma barreira: uma vez que os radiômetros ensaiados ( $\mathrm{R} 1$ e $\mathrm{R} 2$ ) medem uma quantidade proporcional à irradiância eficaz dividida por um valor desconhecido (largura espectral), as quantidades medidas com tais radiômetros não podem ser comparadas diretamente com os valores de referência (medidos com ER e ponderados pelo espectro de ação DIN). Para contornar o problema, a calibração dos radiômetros ensaiados poderia ser realizada, baseada em um fundamento da radiometria, expresso pela Eq. (4.3): a razão entre as quantidades medidas por dois radiômetros, iluminados por uma fonte de radiação com espectro largo, mas espacialmente uniforme, é uma constante: i) para a mesma fonte, caso as responsividades espectrais dos radiômetros sejam diferentes e, ii) para qualquer fonte, caso as responsividades espectrais sejam iguais. Mas as respostas direcionais e sensibilidades dos radiômetros ensaiados não são adequadas para este procedimento. Assim foi escolhido arbitrar um fator de calibração tal que resulte erro nulo em um ponto nas superfícies onde as fontes iluminam. Nos outros pontos de cada superfície os desvios de $\mathrm{R} 1$ e $\mathrm{R} 2$ relativos a ER significam, majoritariamente, diferenças das responsividades espaciais. Contudo este procedimento também significa calibrar $\mathrm{R} 1$ ou $\mathrm{R} 2$ contra ER num ponto do espaço, com as limitações seguintes. As limitações apresentadas na seqüência também são úteis ao entendimento das respostas de R1 e R2.

Os métodos mais comuns de calibração usam uma fonte ou um radiômetro padrão, ou ainda um espectro-radiômetro padrão. Outros métodos podem ser encontrados em Xu e Huang (2003). O método usado foi o espectroradiométrico. 
A Eq. (4.3) pode ser re-escrita na forma:

$$
R=\frac{k \cdot \int_{0}^{\infty} S_{a}(\lambda) \cdot E_{1}(\lambda) d \lambda}{\int_{0}^{\infty} S_{p}(\lambda) \cdot E_{1}(\lambda) d \lambda}
$$

onde $k$ é um fator do detector em teste. Para o método de calibração usado (espectro-radiométrico), a irradiância espectral $E_{1}(\lambda)$ é medida usando um espectro-radiômetro calibrado.

Consideremos que as fontes usadas no processo de calibração de R1 e R2 contra ER (para cada fonte) sejam as próprias fontes fototerápicas. Este método apresenta a vantagem de dispensar a correção espectral, expressa na Eq. (4.12), que seria necessária caso a fonte de calibração fosse outra. Mas apresenta a desvantagem de o fluxo luminoso ser não uniforme.

Os fotodetectores usados nos radiômetros R1 e R2 são de silício, que geralmente apresentam responsividades espaciais não uniformes. A superfície do fotodetector do radiômetro R2 é protegida por uma janela óptica transparente. Neste caso, afora efeitos de eventuais reflexões múltiplas entre a janela e sua superfície sensível, a responsividade espacial do radiômetro é aproximadamente a do fotodetector.

O radiômetro $\mathrm{R} 1$ é dotado de um difusor, que é uma janela óptica abrasada (provavelmente por jatos de areia). Neste caso sua superfície detectora é efetivamente sua janela difusora, mas sua superfície sensível (fotodetectora) continua sendo o silício. Ocorre que, com o uso do difusor, mesmo que o feixe seja uniforme na superfície detectora, a intensidade na superfície sensível não é uniforme: é máxima na região central e decai nas periféricas (Xu et al., 2000). Ocorre ainda que um radiômetro que usa um fotodetector (de silício) mede uma quantidade $\overline{I_{S i}}$, expressa na forma (Xu et al., 2000): 


$$
\overline{I_{S i}}=\frac{I_{0} \iint_{A} I(x, y) \cdot S(x, y) d x d y}{\iint_{A} S(x, y) d x d y}
$$

onde $I(x, y)$ é a distribuição relativa da intensidade na superfície sensível do fotodetector, $I_{0}$ é o valor de pico, $S(x, y)$ é a distribuição relativa da responsividade do fotodetector, e a área $A$ de integração é a receptora. Mas a intensidade média do feixe que ilumina o detector é (Xu et al., 2000):

$$
\bar{I}=\frac{I_{0} \iint_{A} I(x, y) d x d y}{A} .
$$

Logo, $\overline{I_{S i}}$ em (7.2) somente corresponde à intensidade média do feixe, $\bar{l}$ em (7.3), quando: a) ou o feixe luminoso é uniforme: $I(x, y)=1$ ou; b) a responsividade espacial do fotodetector é uniforme: $S(x, y)=1$ (Xu et al., 2000). Nenhuma dessas condições é atendia por R1 e R2 quando iluminados pelas fontes fototerápicas. Assim, num ponto fixo na superfície efetiva (onde as fontes iluminam), as respostas de $\mathrm{R} 1$ e de $\mathrm{R} 2$ não correspondem às intensidades médias do feixe coletado pelas suas superfícies detectoras (janela transparente ou difusora). Note-se, observando a Eq. (7.2), que o problema é semelhante ao do desajuste de um espectro de ação apresentado no Capítulo 4, onde a correção (calibração) do desajuste espectral é possível, mas a calibração somente é válida para a mesma fonte. Mas agora o problema é algo mais complexo: teríamos que conhecer a distribuição $I(x, y)$ de cada fonte. Assim é de pouco valor prático corrigir este tipo de erro. Mas nestas condições (feixe e resposta espacial não uniformes), num ponto fixo do espaço, a dependência entre as respostas de R1 e R2 com a intensidade média do feixe por eles coletados é linear. Desta forma neste ponto do espaço tal diferença pode ser corrigida, desde que as áreas dos dois medidores sejam iguais (ver razões abaixo). Um método possível de correção é o aqui usado: comparar o valor medido por R1 ou R2 com o de um medidor padrão (ER). Mas, como o feixe não é uniforme nas fontes ensaiadas e 
as respostas espaciais dos detectores de R1 e R2 não são uniformes, a correção somente é valida no ponto de calibração. Portanto o fator $k$ na Eq. (7.1) pode variar no espaço. Este tipo de erro espacial é aqui denominado erro de nãouniformidade. O método de correção acima citado não é proposto por Xu et al. (2000), mas sim observando que a razão entre as Eq. (7.2) e Eq. (7.3) é constante num ponto fixo do espaço.

O cálculo ou a medição do erro de não-uniformidade é um assunto complexo e inexplorado pela literatura, mas um método possível é semelhante ao exposto na sessão 4.1 do Capítulo 4: as características (espaciais) de um detector com responsividade espacial diferente da uniforme são calculadas ou medidas para cada distribuição $I(x, y)$. Quando o detector é calibrado para uma distribuição e mede outra, é possível corrigir seguindo os princípios da Eq. (4.13). Embora este método seja de pouco valor prático, conforme acima exposto, pode ser usado para estudar os erros, usando modelos simplificados de $I(x, y)$. Este tópico é uma sugestão de estudos futuros.

Ainda associado a não uniformidade do feixe luminoso, pode ocorrer outro tipo de erro espacial. O fato é que os diâmetros de coleção de R1 e R2 são muito superiores que o de ER (12 mm; $12,8 \mathrm{~mm}$ e $3,9 \mathrm{~mm}$ respectivamente), resultando áreas muito superiores, coletando valores $\mathrm{P} / \mathrm{A}$ superiores ou inferiores (depende da região), relativos a $E R$, onde $P$ é a potência coletada pela superfície detectora (janela transparente ou difusora) com área A. Quando o fluxo varia, áreas diferentes significam irradiâncias médias diferentes. Ou seja, radiômetros com áreas coletoras diferentes medem quantidades diferentes quando o fluxo não é uniforme. O termo quantidade foi usado para alertar que, quando o fluxo não é uniforme, é comum calcular ou medir irradiâncias médias, mas irradiância somente tem significado, por definição, quando o fluxo é uniforme. Ou seja, radiômetros medem uma quantidade proporcional à potência média coletada. Mas, conceitualmente, fluxo por área é diferente de fluxo dentro de uma área: o primeiro implica na uniformidade além da área de medição. Este tipo de erro, aqui denominado de área de coleção, também pode ser compensado somente se for conhecida a distribuição do feixe luminoso, portanto, seria um método de pouco valor prático. Mas, assumindo responsividades espaciais uniformes nos fotodetectores, e quando a distribuição do feixe é modelada por uma co-senoide 
com valor máximo no centro de dois detectores caindo $10 \%$ nas bordas da área de detecção, sendo o diâmetro do detector em calibração aproximadamente três vezes superior ao do radiômetro padrão (que é o caso de $\mathrm{R} 1$ e R2 contra $E R$ ), a diferença entre eles é de 5\%: o medidor com diâmetro maior mede 94,5\% do valor medido pelo outro (Xu et al., 2000).

O espectro-radiômetro ER também usa um corretor co-senoidal, que altera o feixe luminoso na sua superfície de coleção. Neste caso o feixe coletado (do difusor) percorre um caminho mais complexo que os de $\mathrm{R} 1$ e R2; a radiação difusa é coletada por uma fibra óptica que a entrega a grade de difração antes de atingir os elementos sensores. Assim a radiação coletada da superfície difusora por uma fibra óptica multimodo, é difratada e atinge o arranjo de sensores. No caminho da fibra a não uniformidade diminui (Yariv, 1976). Para este arranjo não foi encontrado um estudo semelhante ao de Xu et al., (2000), mas arranjos similares já são usados como medidor de trabalho padrão (apud Xu e Huang, 2000). Em adição, o diâmetro da superfície difusora de ER é 3,9 mm, contra 12 $\mathrm{mm}$ e 12,8 mm de R1 e R2 respectivamente. Desta forma, ER é menos sensível a variações espaciais do feixe. Idealmente, quanto menor o diâmetro de coleção, menor o erro acima descrito. Mas, quanto menor o diâmetro de coleção, menor a potência coletada, e maior dificuldade de detecção. Contudo, durante as medições das fontes fototerápicas ensaiadas foi constatado que as intensidades encontradas são suficientes para comportar um diâmetro de coleção menor, pois a sensibilidade do espectrômetro usado é elevada. Este assunto é complexo, pouco explorado na literatura, e seria uma sugestão de desenvolvimentos futuros.

Os erros espaciais acima descritos, em adição ao erro de direcionalidade (erro co-seno) podem ser as razões dos elevados erros obtidos quando o radiômetro $\mathrm{R} 2$ foi calibrado contra ER nas fontes $\mathrm{H} 1$ e $\mathrm{H} 2$ : no ponto onde foi efetuada a "calibração" o erro é nulo, mas nos outros pontos o erro verificado é de até $113 \%$ (TAB. B4). De fato, a irradiância dessas fontes varia largamente: de 135,3 $\mu \mathrm{W} / \mathrm{cm}^{2}$ a $3109,6 \mu \mathrm{W} / \mathrm{cm}^{2}$ na fonte $\mathrm{H} 1$ (TAB. A7) e de $115,5 \mu \mathrm{W} / \mathrm{cm}^{2}$ a $1546,8 \mu \mathrm{W} / \mathrm{cm}^{2}$ na fonte $\mathrm{H} 2$ (TAB. A10).

Conforme a discussão acima aponta, era esperado que o erro co-seno não fosse corrigido em todos os pontos da superfície efetiva, quando o erro é 
forçado a ser nulo num ponto. Ou seja, as fontes $\mathrm{H} 1$ e $\mathrm{H} 2$ não são pontuais, e o ângulo entre a fonte e detector muda na superfície efetiva. Mas era esperado, somente considerando o erro co-seno, que os erros fossem menores, pois $\mathrm{H} 1 \mathrm{e}$ $\mathrm{H} 2$ se aproximam de fontes pontuais e o ângulo entre as fontes e os pontos de medição varia entre aproximadamente de 36 graus (ponto seis) a 50 graus (ponto um) passando por 43 graus no centro da elipse. Assim, somente considerando o erro co-seno de R2 nesta faixa de ângulos (FIG. 6.2), os erros seriam menores que os obtidos nas superfícies de $\mathrm{H} 1$ e H2. Portanto, somado ao erro co-seno (direcional), outros erros espaciais podem ser importantes.

As fontes F1 e F2 ensaiadas apresentaram menores variações de intensidades nas suas superfícies efetivas. Neste caso o erro máximo encontrado foi de $-28,9 \%$ (R2 no ponto 13), na fonte F2 (TAB. B2). Nos casos de F1 e F2, as fontes são claramente estendidas, com fluxos mais uniformes, significando que o erro co-seno é menos evidente, pois as contribuições do fluxo são progressivamente (co-senoidalmente) menores com o ângulo de incidência. Ou seja, no caso de fluxo difuso e homogêneo, contribuições com ângulos próximos a zero grau são mais importantes que as que incidem com ângulos próximos a 90 graus e 270 graus. Assim erros co-seno nestes casos são menores que os erros encontrados em fontes puntiformes detectadas com ângulos elevados. Contudo, neste caso, os demais erros acima descritos também contribuíram. Mas, uma vez que os erros de não-uniformidade e de área de coleção são oriundos de não uniformidades do fluxo luminoso, no caso de F1 e F2 são menos importantes.

Assim, medições isoladas de R2, calibrado contra ER, nas superfícies das fontes com foco dirigido $(\mathrm{H} 1$ e $\mathrm{H} 2)$ apresentaram erros elevados (superiores a 100\%). Portanto, uma vez que a diferença entre os espectros de ação de ER e R2 não é razão para esses erros encontrados (pois R2 foi calibrado contra ER), pode ser concluído que os erros espaciais e co-seno são importantes, principalmente quando o fluxo luminoso não é uniforme, que é o caso das fontes ensaiadas.

A norma NBR-IEC 60601-2-50:2003 prescreve que a razão entre a irradiância mínima e máxima na faixa entre $400 \mathrm{~nm}$ e $550 \mathrm{~nm}$ seja menor que 0,4. Isto significa que a diferença percentual máxima prescrita, da menor irradiância medida relativa à máxima, é igual a $-60 \%$. Nas fontes $F 1$ e F2, a diferença percentual máxima encontrada foi de: $-45 \%$ (F1); $-49 \%$ (F2); $-95 \%$ (H1) e $-92 \%$ 
(H2). Portanto as fontes F1 e F2 estão em conformidade com a norma referida, enquanto as fontes $\mathrm{H} 1$ e $\mathrm{H} 2$ não estão conformes. Certamente, quanto menor a variação do fluxo na superfície efetiva, menores são os eventuais erros espaciais nas medições.

\subsubsection{Transferência de calibração}

A transferência de calibração é útil quando um radiômetro é calibrado contra uma fonte outra que não aquela sob teste. Na prática, na área que este trabalho foca, é o caso de um radiômetro com espectro de ação aproximado (relativo a um padrão) medindo uma fonte com espectro diferente do usado na calibração. Na prática quase sempre há a necessidade de transferir a calibração, ou seja, corrigir os valores medidos por um radiômetro sempre que mede uma fonte com espectro diferente da usada na calibração. Isto ocorre porque a tecnologia atual de confecção de filtros ópticos não permite ajustes precisos. Caso não seja efetuada a compensação, há erro. Rigorosamente não há como generalizar os erros resultantes por duas razões: i) não há um espectro de ação padrão e; ii) o erro depende das fontes (calibração e teste). Mas os resultados obtidos proporcionam uma mostra dos erros resultantes caso o espectro de ação DIN seja padrão. Dentre as fontes e radiômetros ensaiados, o erro máximo encontrado foi de $22 \%$ e ocorre quando o detector R1 é calibrado com a fonte F2 e mede a fonte H1. Deve ser notado que o método usado permite o cálculo deste tipo de erro usando somente os espectros de ação dos radiômetros e dos espectros relativos das fontes. Deve estar claro que comparações de radiômetros usando os valores medidos diretamente de uma fonte (método comumente usado na literatura), estão sujeitas aos erros espaciais acima descritos (existem outros fatores, mas somente considerando, segundo Xu e Huang, (2003), os mais importantes são: a radiação ambiente e a incerteza na calibração, que somados são inferiores a 1\%). Portanto, os resultados de Vreman et al., (2004), comentados no Capítulo 1, apontando diferenças de até 105\% (quando dois radiômetros comerciais mediram a mesma fonte), são decorrentes do somatório de erros de desajuste dos espectros de ação e de erros espaciais. Assim a explicação de que os erros elevados observados, segundo os autores, decorrem (somente) das diferentes responsividades espectrais dos radiômetros, deve ser 
revista. O termo "somente" foi destacado porque os autores não citam outra causa além da responsividade espectral.

Aproveitando o fato de que as diferenças entre os espectros de ação resultem erros pequenos quando comparados aos erros espaciais, foi explorada a possibilidade de usar um espectro de ação gaussiano, com média $460 \mathrm{~nm}$ e desvio-padrão $26 \mathrm{~nm}$, como uma aproximação do espectro de ação DIN. O erro máximo encontrado, para as fontes ensaiadas, foi de 6\%. Pequeno, portanto, quando comparado aos outros erros encontrados.

O espectro de ação DIN usada foi extraído da norma DIN 5031-10, onde são fornecidos 29 valores da curva, numa tabela, em intervalos de $5 \mathrm{~nm}$. A curva gaussiana analisada pode ser expressa na forma usual $\mathrm{G}(460,26) \mathrm{nm}$. Sabendo a média e desvio-padrão, a curva é facilmente reproduzida com a resolução desejada. Portando é uma forma mais adequada quando o objetivo não é obter um filtro óptico, mas sim calcular a irradiância eficaz, partindo da irradiância espectral medida por um espectro-radiômetro, que é o caso do medidor padrão usado no presente trabalho.

Os princípios da transferência de calibração também são úteis quando o objetivo é alterar um espectro de ação. É o caso em que, no futuro, um espectro de ação venha a ser aceito como padrão. Neste caso seria útil corrigir valores de irradiâncias eficazes estabelecidos usando o espectro de ação DIN (ou outro qualquer), segundo um novo espectro de ação. Na seqüência esta possibilidade é explorada.

Para corrigir um valor de irradiância eficaz obtido segundo um espectro de ação, DIN $S_{a}(\lambda)$ (agora aproximada), é suficiente aplicar a Eq. (4.10), usando uma nova curva de ação $S_{p}(\lambda)$ :

$$
E_{e f}=\frac{C_{p}}{C_{a}} \cdot Q_{a}
$$


onde $E_{e f}$ é a irradiância eficaz segundo a curva $S_{p}(\lambda)$, e $Q_{a}$ é a irradiância eficaz segundo a curva $S_{a}(\lambda)$. Para que seja possível tal correção, além da necessidade de registrar o valor $Q_{a}$, como é usual, há a necessidade de registrar a característica do detector para a fonte em que $Q_{a}$ foi medida usando $S_{a}(\lambda): C_{a}$. Quando $S_{p}(\lambda)$ se torna padrão há a necessidade de medir ou calcular a característica do detector para a fonte em que $Q_{a}$ foi medida usando $S_{p}(\lambda): C_{p}$. Para calcular $C_{p}$, a Eq. (4.8) é usada:

$$
C_{p}=\frac{\int_{\lambda 1}^{\lambda 2} S_{p}(\lambda) \cdot E_{1}(\lambda) d \lambda}{\int_{\lambda 1}^{\lambda 2} E_{1}(\lambda) d \lambda}=\frac{E_{e f}}{E_{1}}
$$

onde $E_{1}(\lambda)$ é a fonte em $Q_{a}$ foi obtido. Portanto é necessário conhecer a fonte. Mas deve ser observado na Eq. (7.5) que a irradiância espectral relativa da fonte é suficiente. Assim, no caso de fontes comerciais, basta ser incentivado aos fabricantes disponibilizar o espectro relativo de suas fontes. Resta incentivar os fabricantes de radiômetros (ou espectro-radiômetros) a disponibilizar os espectros de ação usados. Com este procedimento (conhecendo o espectro de ação e o espectro relativo da fonte), valores de irradiâncias eficazes medidos usando quaisquer espectros de ação podem ser corrigidos. A norma IEC 60601-250:2008, disponibilizada em dezembro de 2008, torna obrigatório (na primeira edição, em 2000, era opcional), ao fabricante, disponibilizar a irradiância da fonte, na faixa entre $320 \mathrm{~nm}$ a $550 \mathrm{~nm}$, mediada em intervalos de $5 \mathrm{~nm}$, lembrando que normas IEC são seguidas por mais de 50 países, entre eles, o Brasil.

A norma NBR IEC 60601-2-50:2003 também determina que o fabricante deve informar a irradiância TOTAL da fonte, $E_{b i l}$, definida na norma como a irradiância da fonte na faixa entre $400 \mathrm{~nm}$ a $550 \mathrm{~nm}$, expressa como: 


$$
E_{b i l}=\int_{400}^{550} E(\lambda) d \lambda
$$

Mas não prescreve um espectro de ação, embora reconheça que a efetividade da fonte no tratamento dependa tanto da intensidade como do espectro da fonte. De fato, esta faixa está em concordância com a literatura. É pouco provável que esta faixa mude em função de novos conhecimentos. Abaixo de $400 \mathrm{~nm}$, há restrições, onde efeitos nocivos ocorrem. Acima de $550 \mathrm{~nm}$, não há qualquer evidência sugerindo efeitos fotoquímicos. Assim, seria suficiente o fabricante informar a irradiância espectral relativa da fonte na faixa entre $400 \mathrm{~nm}$ e $550 \mathrm{~nm}$.

\subsection{Irradiância eficaz média}

Comparando as irradiâncias espectrais médias medidas via R1 e R2, a maior diferença obtida foi $128 \%$, tomando arbitrariamente $\mathrm{R} 1$ como referência, quando mediram fontes com foco dirigido. A diferença decorre das diferenças de suas respostas espectrais, espaciais e possivelmente por diferenças nas larguras espectrais usadas na calibração.

As irradiâncias das quatro fontes ensaiadas foram medidas em 18 regiões na superfície efetiva (área útil onde o neonato recebe a radiação) das fontes com lâmpadas fluorescentes, seguindo prescrições da norma NBR IEC 60601-2-50:2003, e em 24 regiões, nas superfícies efetivas das fontes halógenas, segundo uma proposta aqui apresentada, uma vez que a norma acima não prescreve as regiões de medição no caso de fontes com foco dirigido, deixando a critério do fabricante. Nos manuais das fontes ensaiadas também não há critérios sugeridos.

A norma NBR IEC 60601-2-50:2003 determina que o fabricante deve informar a irradiância TOTAL média dos dezoito pontos descritos na FIG. 5.2. Uma vez que a relação entre a irradiância TOTAL e a irradiância eficaz é linear (ver Eq. (4.8)), no texto que segue não há distinção entre as duas quantidades $E_{\text {bil }}$ na Eq. (7.6) e $E_{D I N}$ na Eq. (5.1). Note-se que os dezoito pontos na superfície de referência, FIG. 5.2, estão localizados nos centros geométricos de dezoito regiões, quadradas, com lados iguais a $10 \mathrm{~cm}$. Uma vez que as áreas das regiões 
são iguais, o valor resultante do somatório das potências $P$ coletadas em cada área $(10 \mathrm{~cm} \times 10 \mathrm{~cm})$ dividido pela área total $\mathrm{A}(30 \mathrm{~cm} \times 60 \mathrm{~cm}), \mathrm{P} / \mathrm{A}$ é igual ao valor médio das irradiâncias medidas nos dezoito pontos.

No caso das fontes $\mathrm{H} 1$ e $\mathrm{H} 2$, as áreas das 24 regiões nas usas superfícies elípticas apresentam diferenças. Assim o valor resultante do somatório das potências $\mathrm{P}$ coletadas em cada área dividido pela área total não é igual ao valor médio das irradiâncias medidas nos 24 pontos. Considerando as irradiâncias medidas por ER, o erro máximo encontrado é de $43 \%$ e ocorre quando ER mede a fonte $\mathrm{H} 1 \quad\left(848 \mu \mathrm{W} / \mathrm{cm}^{2}\right.$ e $1216 \mu \mathrm{W} / \mathrm{cm}^{2}$, valores de P/A e $\sum_{n=1}^{24} E_{n} / n$, respectivamente), considerando ainda $\mathrm{P} / \mathrm{A}$ como referência. Este resultado somente reflete $o$ fato de que as maiores intensidades estão concentradas nas regiões centrais, conforme mostram as TAB. A7 a TAB. A12. Claramente o valor de $\sum_{n=1}^{24} E_{n} / n$ superestima a potência coletada na área da superfície efetiva.

A maioria dos estudos na literatura não cita o método usado para estimar a irradiância média na superfície efetiva (e.g, Ebbesen, 2003). Outros citam três pontos (e.g., Tan, 1982). Caso fosse medido um único ponto nas superfícies efetivas de $\mathrm{H} 1$ e $\mathrm{H} 2$, e caso fosse escolhido o ponto de maior intensidade, tem-se $3109,6 \mu W / \mathrm{cm}^{2}$ e $1546,8 \mu W / \mathrm{cm}^{2}$ em $\mathrm{H} 1$ e $\mathrm{H} 2$ respectivamente, medidos pelo $\mathrm{ER}$, contra os valores médios de $848 \mu \mathrm{W} / \mathrm{cm}^{2} \mathrm{e}$ $577 \mu \mathrm{W} / \mathrm{cm}^{2}$ em H1 e H2. Portanto uma diferença de até $267 \%$, muito superior às diferenças resultantes de desajuste da responsividade espectral ou erros espaciais. Fica evidente, portanto, que estimativas da irradiância eficaz média por medições em um único ponto (ou em três pontos, comuns na literatura), são inadequadas.

No caso das fontes F1 e F2 (estendidas), este tipo de erro (acima) é $27 \%$ para F1 e 29\% para F2 (TAB. A1 e A4), refletindo o fato de que as variações espaciais do fluxo luminoso dessas fontes são menores que as encontradas nas fontes com foco dirigido.

Portanto, pode ser verificado que, para as fontes e medidores ensaiados, as menores diferenças entre os medidores comerciais estudados e 0 de referência usado são as decorrentes de desajuste de suas responsividades 
espectrais, que ocorrem quando são usados em uma fonte com espectro diferente da usada em sua calibração. E os maiores desvios ocorrem na determinação da irradiância eficaz média na superfície efetiva.

Antes de continuar, um breve comentário sobre dose: um conceito comum de dose em medicina, farmacologia e toxicologia é: a quantidade de uma droga prescrita, tomada numa única vez.

Embora irradiância eficaz seja entendida como dose na área de fototerapia de neonatos, tem sido verificado que o decréscimo da bilirrubina em um tratamento fototerápico depende não somente da irradiância como também da área irradiada e do tempo de exposição. Fica então evidente que somente a irradiância não especifica a dose.

É estimado que aproximadamente $33 \%$ da área de um neonato seja irradiada por fontes estendidas que iluminam unilateralmente 0 neonato, significando áreas aproximadas de $427 \mathrm{~cm}^{2}$ e $706 \mathrm{~cm}^{2}$ de pré-termos e de termos, respectivamente (Dicken, 2000). As fontes de foco dirigido ensaiadas iluminam áreas significativamente menores: $141 \mathrm{~cm}^{2}$ e $266 \mathrm{~cm}^{2}$ de $\mathrm{H} 1$ e $\mathrm{H} 2$, respectivamente. Os eixos maiores das elipses onde seus feixes incidem na superfície efetiva são $15 \mathrm{~cm}$ e $19 \mathrm{~cm}$ de $\mathrm{H} 1$ e $\mathrm{H}_{2}$, respectivamente. Os comprimentos médios de pré-termos e de termo são $30 \mathrm{~cm} \mathrm{e} 60 \mathrm{~cm}$ respectivamente. Assim $\mathrm{H} 1$ e $\mathrm{H} 2$ não iluminam todo corpo do neonato e menos de $33 \%$ é irradiado. Por outro lado, as fontes F1 e F2 iluminam uma área superior a $30 \mathrm{~cm}$ x $60 \mathrm{~cm}$. Fica, portanto, evidente que comparar irradiâncias entre fontes estendidas com as de foco dirigido não é apropriado. Este assunto é conhecido (Dicken, 2000), mas não há uma proposta de normalização na literatura.

Seria, como uma sugestão, mais adequado como uma sugestão, considerar a área sugerida pela norma NBR IEC 60601-2-50:2003: $30 \mathrm{~cm}$ x $60 \mathrm{~cm}$ para fontes estendidas, que irradiam áreas superiores às de neonatos. Para $\mathrm{H} 1 \mathrm{e}$ $\mathrm{H} 2$, que irradiam áreas menores, é usado um fator de correção igual a suas áreas divididas por $700 \mathrm{~cm}^{2}$. No caso de $\mathrm{H} 1$, a irradiância eficaz média é multiplicada por $141 / 700$ e para $\mathrm{H} 2,266 / 700$. 


\subsection{Conseqüências dos erros nas medições}

A partir do trabalho de Bonta e Washaw (1976), convencionou-se que a menor irradiância clinicamente eficaz no tratamento de icterícia por fototerapia é de $4 \mu \mathrm{W} / \mathrm{cm}^{2} \mathrm{~nm}$, pois irradiâncias menores podem resultar desde a necessidade de transfusão até danos irreversíveis no sistema nervoso central (Kliemann, Noharama, 2001). Assim poderíamos concluir: um radiômetro que indica 6 $\mu \mathrm{W} / \mathrm{cm}^{2} \mathrm{~nm}$ e na verdade somente há $3 \mu \mathrm{W} / \mathrm{cm}^{2} \mathrm{~nm}$ é inadequado. Contudo, provavelmente não há uma divisão precisa entre doses efetivas ou não, bem como é difícil saber o significado da irradiância de $4 \mu \mathrm{W} / \mathrm{cm}^{2} \mathrm{~nm}$ (mínima eficaz), pois o espectro de ação, o método de medição da irradiância eficaz média na superfície efetiva e a definição da largura do espectro considerado não são disponíveis no trabalho de Bonta e Washaw (1976). Buscando uma solução a estas questões, o presente trabalho apresenta, como uma contribuição principal, um método que aplicado a radiometria na fototerapia permite não somente quantificar a irradiância eficaz usando um espectro de ação aqui denominada padrão, como disponibilizar meios de corrigir irradiâncias eficazes quando outros espectros de ação forem considerados. Mas, usando a informação disponível na literatura, na seqüência é efetuada uma análise das conseqüências de erros nas medições da irradiância efetiva.

O trabalho de Tan (1982) é aqui explorado pelas seguintes razões: o autor cita a fonte usada: lâmpada Philips TL20W/52, cujo espectro é largamente conhecido; cita o radiômetro e filtro óptico usado; informa a irradiância eficaz e; cita os locais onde mediu a radiação (média de medições da cabeça, tronco e joelhos). Embora os métodos usados não sejam satisfatórios, à luz dos resultados aqui apresentados, este trabalho apresenta uma quantidade de informações superior a outros semelhantes.

Tan (1982) acompanhou o tratamento fototerápico de 9 grupos de neonatos contendo 12 pacientes em cada grupo. Os grupos foram submetidos à irradiâncias eficazes diferentes e crescentes. Quando o nível de bilirrubina era igual ou menor que um valor pré-estabelecido $(11 \mathrm{mg} / \mathrm{dl})$, o neonato tinha 0 tratamento fototerápico suspenso. A TAB. 7.1 apresenta os valores das 
irradiâncias eficazes utilizados em cada grupo e o número de neonatos que tiveram alta $24 \mathrm{~h}$ e $48 \mathrm{~h}$ depois de iniciados os tratamentos.

Tabela 7.1 - Valores das irradiâncias eficazes utilizados em cada grupo e o número de neonatos que tiveram alta $24 \mathrm{~h}$ e $48 \mathrm{~h}$ depois de iniciados os tratamentos, extraídos de Tan (1982).

\begin{tabular}{ccccccccc}
\hline \multicolumn{1}{c}{ Grupos } \\
\hline 1 & 2 & 3 & 4 & 5 & 6 & 7 & 8 & 9 \\
\hline 2 & 2 & 4 & 5 & 8 & 11 & 11 & 10 & 12 \\
& & & & & & & & \\
6 & 7 & 9 & 9 & 12 & 12 & 12 & 12 & 12 \\
134 & 447 & 523 & 619 & 1101 & 1612 & 1690 & 2011 & 2319 \\
\hline
\end{tabular}

Segundo os resultados de Tan (1982), todos os neonatos do grupo 9 foram tratados em $24 \mathrm{~h}$. Mas apenas oito (67\%) dos neonatos do grupo cinco tiveram alta em $24 \mathrm{~h}$. A diferença percentual de irradiância entre os grupos nove e cinco é $-52 \%$. Somente depois de $48 \mathrm{~h}$ todos os neonatos do grupo cinco tiveram alta.

Assim, usando o estudo de Tan (1982), é possível estimar que um erro de $-52 \%$ na medição da irradiância significa a adição de um dia do tratamento para $33 \%$ dos neonatos, e conseqüentemente custos adicionais. 


\section{CONCLUSÕES}

Este trabalho apresenta um conjunto de métodos, adaptados da radiometria ultravioleta de banda larga, que possibilitam a calibração de radiômetros seguindo um espectro de ação da fototerapia no tratamento de icterícia neonatal. Dada a ausência de um espectro de ação largamente aceito, os métodos apresentados permitem transferir calibrações de radiômetros quando o espectro da fonte e ou o espectro de ação são alterados, possibilitando comparações entre irradiâncias medidas por diferentes radiômetros e fontes, segundo um espectro de ação.

Usando os métodos de calibração e transferência de calibração, foram caracterizadas quatro fontes fototerápicas e dois radiômetros comerciais de fabricação nacional.

Considerando somente as responsividades espectrais dos radiômetros e fontes ensaiadas, foram estimadas diferenças de irradiâncias entre $-4 \%$ a $22 \%$ decorrentes de desajustes nas responsividades dos radiômetros quando medem fontes com espectro diferente da usada na calibração, relativos ao espectro de ação sugerido na norma DIN 5031-10.

As maiores diferenças encontradas nas irradiâncias médias nas fontes estudadas são decorrentes do método de medição e de cálculo da irradiância média eficaz, e principalmente das não uniformidades dos feixes luminosos das fontes com foco dirigido.

Foi observada diferença de até $43 \%$ quando o método usado para calcular a irradiância média eficaz das fontes ensaiadas com foco dirigido é a média aritmética.

Diferenças de até $267 \%$ foram observadas quando a irradiância de um único ponto é comparada com a irradiância média na área iluminada por uma das fontes de foco dirigido ensaiada.

Assim, embora seja necessário padronizar medidores de irradiância eficaz, é fortemente sugerido padronizar o método de medição da irradiância eficaz média. 
ANEXO A

Tabela A1 - Valores de irradiâncias eficazes (unidades em $\mu \mathrm{W} / \mathrm{cm}^{2}$ ) de três medições (L1, L2 e L3), efetuadas com o espectro-radiômetro ER a $25 \mathrm{~cm}$ da fonte $\mathrm{F} 1$. Os pontos de 1 a 18 estão distribuídos conforme recomendação da norma NBR IEC 60601.2.50.

\begin{tabular}{|c|c|c|c|c|c|}
\hline Ponto & $\begin{array}{c}\text { Medida } 1 \\
\left(\mu \mathrm{W} / \mathrm{cm}^{2}\right)\end{array}$ & $\begin{array}{c}\text { Medida } 2 \\
\left(\mu \mathrm{W} / \mathrm{cm}^{2}\right)\end{array}$ & $\begin{array}{l}\text { Medida } 3 \\
\left(\mu \mathrm{W} / \mathrm{cm}^{2}\right)\end{array}$ & $\begin{array}{c}\text { Valor médio } \\
\left(\mu \mathrm{W} / \mathrm{cm}^{2}\right)\end{array}$ & $\begin{array}{c}\text { Desvio padrão } \\
\left(\mu \mathrm{W} / \mathrm{cm}^{2}\right)\end{array}$ \\
\hline 1 & 677 & 765 & 788 & 743 & 59 \\
\hline 2 & 985 & 1092 & 928 & 1002 & 83 \\
\hline 3 & 1128 & 1105 & 950 & 1061 & 97 \\
\hline 4 & 1118 & 1050 & 987 & 1052 & 66 \\
\hline 5 & 989 & 1089 & 1107 & 1062 & 64 \\
\hline 6 & 746 & 709 & 649 & 701 & 49 \\
\hline 7 & 794 & 778 & 879 & 817 & 54 \\
\hline 8 & 1142 & 1267 & 1330 & 1246 & 96 \\
\hline 9 & 1339 & 1124 & 1101 & 1188 & 131 \\
\hline 10 & 1348 & 1267 & 1254 & 1290 & 51 \\
\hline 11 & 1152 & 1175 & 1022 & 1116 & 83 \\
\hline 12 & 859 & 773 & 820 & 817 & 43 \\
\hline 13 & 731 & 679 & 767 & 726 & 44 \\
\hline 14 & 1022 & 940 & 846 & 936 & 88 \\
\hline 15 & 1174 & 1151 & 1071 & 1132 & 54 \\
\hline 16 & 1135 & 1214 & 1201 & 1183 & 42 \\
\hline 17 & 974 & 915 & 906 & 932 & 37 \\
\hline 18 & 697 & 599 & 695 & 664 & 56 \\
\hline \multirow[t]{2}{*}{ ER } & F1 & - & $\begin{array}{l}\text { Média } \\
\left(\mu \mathrm{W} / \mathrm{cm}^{2}\right)\end{array}$ & 980 & \\
\hline & & & $\begin{array}{c}\text { Desvio padrão } \\
\left(\mu \mathrm{W} / \mathrm{cm}^{2}\right)\end{array}$ & 198 & \\
\hline
\end{tabular}


Tabela A2 - Valores de irradiâncias espectrais eficazes (unidades em $\mu \mathrm{W} / \mathrm{cm}^{2} . n m$ ) de três medições (L1, L2 e L3), efetuadas com o radiômetro $R 1$ a $25 \mathrm{~cm}$ da fonte $F 1$. Os pontos de 1 a 18 estão distribuídos conforme recomendação da norma NBR IEC 60601.2.50.

\begin{tabular}{|c|c|c|c|c|c|}
\hline Ponto & $\begin{array}{c}\text { Medida } 1 \\
\left(\mu \mathrm{W} / \mathrm{cm}^{2} \mathrm{~nm}\right)\end{array}$ & $\begin{array}{c}\text { Medida } 2 \\
\left(\mu \mathrm{W} / \mathrm{cm}^{2} \mathrm{~nm}\right) \\
\end{array}$ & $\begin{array}{l}\text { Medida } 3 \\
\left(\mu \mathrm{W} / \mathrm{cm}^{2} \mathrm{~nm}\right) \\
\end{array}$ & $\begin{array}{l}\text { Valor médio } \\
\left(\mu \mathrm{W} / \mathrm{cm}^{2} \mathrm{~nm}\right)\end{array}$ & $\begin{array}{c}\text { Desvio padrão } \\
\left(\mu \mathrm{W} / \mathrm{cm}^{2} \mathrm{~nm}\right)\end{array}$ \\
\hline 1 & 5,8 & 6,4 & 6,1 & 6,1 & 0,3 \\
\hline 2 & 9,8 & 10,0 & 9,7 & 9,8 & 0,2 \\
\hline 3 & 11,6 & 11,5 & 11,9 & 11,7 & 0,2 \\
\hline 4 & 11,6 & 12,0 & 12,0 & 11,9 & 0,2 \\
\hline 5 & 10,6 & 10,9 & 11,0 & 10,8 & 0,2 \\
\hline 6 & 7,3 & 7,5 & 7,5 & 7,4 & 0,1 \\
\hline 7 & 7,6 & 7,6 & 7,6 & 7,6 & 0,0 \\
\hline 8 & 11,7 & 11,8 & 11,7 & 11,7 & 0,1 \\
\hline 9 & 13,8 & 13,6 & 13,8 & 13,7 & 0,1 \\
\hline 10 & 14,1 & 14,0 & 13,9 & 14,0 & 0,1 \\
\hline 11 & 13,6 & 12,2 & 12,1 & 12,6 & 0,8 \\
\hline 12 & 8,1 & 8,5 & 8,6 & 8,4 & 0,3 \\
\hline 13 & 6,2 & 6,6 & 6,6 & 6,2 & 0,2 \\
\hline 14 & 9,7 & 10,0 & 10,0 & 9,9 & 0,2 \\
\hline 15 & 11,4 & 11,2 & 11,6 & 11,4 & 0,2 \\
\hline 16 & 11,3 & 11,1 & 11,6 & 11,3 & 0,3 \\
\hline 17 & 10,5 & 10,0 & 10,9 & 10,5 & 0,5 \\
\hline 18 & 6,3 & 6,5 & 7,5 & 6,8 & 0,6 \\
\hline \multirow[t]{2}{*}{$\mathrm{R} 1$} & $\mathrm{~F} 1$ & & $\begin{array}{c}\text { Média } \\
\left(\mu \mathrm{W} / \mathrm{cm}^{2} \mathrm{~nm}\right)\end{array}$ & 10,1 & \\
\hline & & & $\begin{array}{c}\text { Desvio padrão } \\
\left(\mu \mathrm{W} / \mathrm{cm}^{2} \mathrm{~nm}\right)\end{array}$ & 2,5 & \\
\hline
\end{tabular}


Tabela A3 - Valores de irradiâncias espectrais eficazes (unidades em $\mu \mathrm{W} / \mathrm{cm}^{2} . n m$ ) de três medições (L1, L2 e L3), efetuadas com o radiômetro $R 2$ a $25 \mathrm{~cm}$ da fonte $F 1$. Os pontos de 1 a 18 estão distribuídos conforme recomendação da norma NBR IEC 60601.2.50.

\begin{tabular}{|c|c|c|c|c|c|}
\hline Ponto & $\begin{array}{l}\text { Medida 1 } \\
\left(\mu \mathrm{W} / \mathrm{cm}^{2} \mathrm{~nm}\right)\end{array}$ & $\begin{array}{c}\text { Medida } 2 \\
\left(\mu \mathrm{W} / \mathrm{cm}^{2} \mathrm{~nm}\right)\end{array}$ & $\begin{array}{l}\text { Medida } 3 \\
\left(\mu \mathrm{W} / \mathrm{cm}^{2} \mathrm{~nm}\right)\end{array}$ & $\begin{array}{l}\text { Valor médio } \\
\left(\mu \mathrm{W} / \mathrm{cm}^{2} \mathrm{~nm}\right)\end{array}$ & $\begin{array}{c}\text { Desvio padrão } \\
\left(\mu \mathrm{W} / \mathrm{cm}^{2} \mathrm{~nm}\right)\end{array}$ \\
\hline 1 & 5,4 & 5,3 & 5,1 & 5,3 & 0,2 \\
\hline 2 & 9,8 & 8,8 & 9,0 & 9,2 & 0,5 \\
\hline 3 & 11,1 & 9,9 & 10,0 & 10,3 & 0,7 \\
\hline 4 & 10,9 & 10,1 & 10,9 & 10,6 & 0,5 \\
\hline 5 & 7,8 & 9,0 & 8,6 & 8,5 & 0,6 \\
\hline 6 & 5,5 & 5,5 & 5,9 & 5,6 & 0,2 \\
\hline 7 & 7,6 & 7,0 & 6,8 & 7,1 & 0,4 \\
\hline 8 & 11,2 & 11,3 & 11,3 & 11,3 & 0,1 \\
\hline 9 & 112,5 & 12,6 & 12,5 & 12,4 & 0,1 \\
\hline 10 & 12,5 & 12,5 & 12,5 & 12,5 & 0,0 \\
\hline 11 & 10,5 & 10,2 & 10,3 & 10,3 & 0,2 \\
\hline 12 & 6,4 & 6,1 & 6,3 & 6,3 & 0,2 \\
\hline 13 & 6,4 & 6,0 & 6,2 & 6,2 & 0,2 \\
\hline 14 & 9,0 & 8,9 & 9,0 & 9,0 & 0,1 \\
\hline 15 & 9,8 & 10,0 & 10,2 & 10,0 & 0,2 \\
\hline 16 & 10,2 & 9,1 & 10,0 & 9,8 & 0,6 \\
\hline 17 & 8,4 & 7,3 & 7,8 & 7,8 & 0,6 \\
\hline 18 & 5,1 & 4,8 & 4,7 & 4,9 & 0,2 \\
\hline \multirow[t]{2}{*}{$\mathrm{R} 2$} & $\mathrm{~F} 1$ & & $\begin{array}{c}\text { Média } \\
\left(\mu \mathrm{W} / \mathrm{cm}^{2} \mathrm{~nm}\right)\end{array}$ & 8,7 & \\
\hline & & & $\begin{array}{c}\text { Desvio padrão } \\
\left(\mu \mathrm{W} / \mathrm{cm}^{2} \mathrm{~nm}\right)\end{array}$ & 2,4 & \\
\hline
\end{tabular}


Tabela A4 - Valores de irradiâncias eficazes (unidades em $\mu \mathrm{W} / \mathrm{cm}^{2}$ ) de três medições ( $L 1$, L2 e L3), efetuadas com o espectro-radiômetro ER a $25 \mathrm{~cm}$ da fonte $\mathrm{F} 2$. Os pontos de 1 a 18 estão distribuídos conforme recomendação da norma NBR IEC 60601.2.50.

\begin{tabular}{|c|c|c|c|c|c|}
\hline Ponto & $\begin{array}{l}\text { Medida } 1 \\
\left(\mu \mathrm{W} / \mathrm{cm}^{2} \mathrm{~nm}\right)\end{array}$ & $\begin{array}{l}\text { Medida } 2 \\
\left(\mu \mathrm{W} / \mathrm{cm}^{2} \mathrm{~nm}\right)\end{array}$ & $\begin{array}{l}\text { Medida } 3 \\
\left(\mu \mathrm{W} / \mathrm{cm}^{2} \mathrm{~nm}\right)\end{array}$ & $\begin{array}{l}\text { Valor médio } \\
\left(\mu \mathrm{W} / \mathrm{cm}^{2} \mathrm{~nm}\right)\end{array}$ & $\begin{array}{l}\text { Desvio padrão } \\
\left(\mu \mathrm{W} / \mathrm{cm}^{2} \mathrm{~nm}\right)\end{array}$ \\
\hline 1 & 949 & 1001 & 829 & 926 & 88,2 \\
\hline 2 & 1032 & 1391 & 1108 & 1177 & 189 \\
\hline 3 & 1502 & 1562 & 1350 & 1471 & 109 \\
\hline 4 & 1470 & 1553 & 1349 & 1457 & 103 \\
\hline 5 & 1042 & 1042 & 1194 & 1093 & 88 \\
\hline 6 & 743 & 967 & 869 & 860 & 112 \\
\hline 7 & 789 & 981 & 868 & 879 & 97 \\
\hline 8 & 1189 & 1432 & 1274 & 1298 & 123 \\
\hline 9 & 1365 & 1684 & 1465 & 1505 & 163 \\
\hline 10 & 1379 & 1651 & 1462 & 1497 & 139 \\
\hline 11 & 1200 & 1400 & 1263 & 1288 & 102 \\
\hline 12 & 742 & 995 & 929 & 889 & 131 \\
\hline 13 & 1024 & 828 & 1073 & 975 & 130 \\
\hline 14 & 1150 & 1198 & 1150 & 1166 & 28 \\
\hline 15 & 1211 & 1366 & 1243 & 1273 & 82 \\
\hline 16 & 1177 & 1331 & 1224 & 1244 & 79 \\
\hline 17 & 1090 & 1132 & 1073 & 1098 & 30 \\
\hline 18 & 780 & 792 & 744 & 772 & 25 \\
\hline \multirow[t]{2}{*}{ ER } & $\mathrm{F} 2$ & & $\begin{array}{c}\text { Média } \\
\left(\mu \mathrm{W} / \mathrm{cm}^{2} \mathrm{~nm}\right)\end{array}$ & 1159 & \\
\hline & & & $\begin{array}{c}\text { Desvio padrão } \\
\left(\mu \mathrm{W} / \mathrm{cm}^{2} \mathrm{~nm}\right)\end{array}$ & 238 & \\
\hline
\end{tabular}


Tabela A5 - Valores de irradiâncias espectrais eficazes (unidades em $\mu \mathrm{W} / \mathrm{cm}^{2} . n m$ ) de três medições (L1, L2 e L3), efetuadas com o radiômetro $R 1$ a $25 \mathrm{~cm}$ da fonte $F 2$. Os pontos de 1 a 18 estão distribuídos conforme recomendação da norma NBR IEC 60601.2.50.

\begin{tabular}{|c|c|c|c|c|c|}
\hline Ponto & $\begin{array}{l}\text { Medida } 1 \\
\left(\mu \mathrm{W} / \mathrm{cm}^{2} \mathrm{~nm}\right)\end{array}$ & $\begin{array}{l}\text { Medida } 2 \\
\left(\mu \mathrm{W} / \mathrm{cm}^{2} \mathrm{~nm}\right)\end{array}$ & $\begin{array}{c}\text { Medida } 3 \\
\left(\mu \mathrm{W} / \mathrm{cm}^{2} \mathrm{~nm}\right)\end{array}$ & $\begin{array}{l}\text { Valor médio } \\
\left(\mu \mathrm{W} / \mathrm{cm}^{2} \mathrm{~nm}\right)\end{array}$ & $\begin{array}{c}\text { Desvio padrão } \\
\left(\mu \mathrm{W} / \mathrm{cm}^{2} \mathrm{~nm}\right)\end{array}$ \\
\hline 1 & 7,0 & 7,0 & 7,4 & 7,1 & 0,2 \\
\hline 2 & 10,8 & 10,9 & 10,8 & 10,8 & 0,1 \\
\hline 3 & 12,6 & 13,1 & 13,4 & 13,0 & 0,4 \\
\hline 4 & 13,1 & 13,0 & 12,7 & 12,9 & 0,2 \\
\hline 5 & 11,6 & 11,5 & 11,4 & 11,5 & 0,1 \\
\hline 6 & 8,1 & 8,2 & 8,4 & 8,2 & 0,2 \\
\hline 7 & 8,0 & 8,0 & 7,9 & 8,0 & 0,1 \\
\hline 8 & 12,5 & 12,9 & 13,0 & 12,8 & 0,3 \\
\hline 9 & 15,1 & 15,3 & 15,2 & 15,2 & 0,1 \\
\hline 10 & 15,7 & 15,5 & 15,4 & 15,5 & 0,2 \\
\hline 11 & 13,7 & 13,8 & 13,4 & 13,6 & 0,2 \\
\hline 12 & 9,7 & 9,6 & 9,2 & 9,5 & 0,3 \\
\hline 13 & 8,6 & 7,0 & 7,0 & 7,5 & 0,9 \\
\hline 14 & 11,4 & 10,8 & 10,6 & 10,9 & 0,4 \\
\hline 15 & 13,0 & 12,8 & 12,5 & 12,8 & 0,3 \\
\hline 16 & 13,0 & 13,4 & 13,0 & 13,1 & 0,2 \\
\hline 17 & 11,0 & 11,4 & 11,4 & 11,3 & 0,2 \\
\hline 18 & 7,9 & 8,3 & 7,5 & 7,9 & 0,3 \\
\hline \multirow[t]{2}{*}{$\mathrm{R} 1$} & $\mathrm{~F} 2$ & & $\begin{array}{c}\text { Média } \\
\left(\mu \mathrm{W} / \mathrm{cm}^{2} \mathrm{~nm}\right)\end{array}$ & 11,2 & \\
\hline & & & $\begin{array}{c}\text { Desvio padrão } \\
\left(\mu \mathrm{W} / \mathrm{cm}^{2} \mathrm{~nm}\right)\end{array}$ & 2,6 & \\
\hline
\end{tabular}


Tabela A6 - Valores de irradiâncias espectrais eficazes (unidades em $\mu \mathrm{W} / \mathrm{cm}^{2} . n m$ ) de três medições ( $L 1$, $L 2$ e $L 3$ ), efetuadas com o radiômetro $R 2$ a $25 \mathrm{~cm}$ da fonte $F 2$. Os pontos de 1 a 18 estão distribuídos conforme recomendação da norma NBR IEC 60601.2.50.

\begin{tabular}{|c|c|c|c|c|c|}
\hline Ponto & $\begin{array}{c}\text { Medida } 1 \\
\left(\mu \mathrm{W} / \mathrm{cm}^{2} \mathrm{~nm}\right) \\
\end{array}$ & $\begin{array}{c}\text { Medida } 2 \\
\left(\mu \mathrm{W} / \mathrm{cm}^{2} \mathrm{~nm}\right) \\
\end{array}$ & $\begin{array}{l}\text { Medida } 3 \\
\left(\mu \mathrm{W} / \mathrm{cm}^{2} \mathrm{~nm}\right) \\
\end{array}$ & $\begin{array}{l}\text { Valor médio } \\
\left(\mu \mathrm{W} / \mathrm{cm}^{2} \mathrm{~nm}\right)\end{array}$ & $\begin{array}{c}\text { Desvio padrão } \\
\left(\mu \mathrm{W} / \mathrm{cm}^{2} \mathrm{~nm}\right)\end{array}$ \\
\hline 1 & 8,7 & 7,3 & 6,6 & 7,5 & 1,1 \\
\hline 2 & 13,3 & 11,3 & 10,6 & 11,7 & 1,4 \\
\hline 3 & 15,2 & 12,7 & 11,8 & 13,2 & 1,8 \\
\hline 4 & 16,2 & 12,8 & 12,2 & 13,7 & 2,2 \\
\hline 5 & 13,5 & 11,0 & 9,6 & 11,4 & 2,0 \\
\hline 6 & 7,8 & 6,9 & 6,7 & 7,1 & 0,6 \\
\hline 7 & 10,2 & 8,6 & 7,9 & 8,9 & 1,2 \\
\hline 8 & 13,8 & 12,9 & 12,4 & 13,0 & 0,7 \\
\hline 9 & 16,1 & 15,0 & 14,1 & 15,1 & 1,0 \\
\hline 10 & 15,9 & 14,9 & 14,0 & 14,9 & 1,0 \\
\hline 11 & 12,9 & 12,6 & 11,8 & 12,4 & 0,6 \\
\hline 12 & 8,4 & 7,2 & 7,6 & 7,7 & 0,6 \\
\hline 13 & 7,4 & 6,8 & 6,4 & 6,9 & 0,5 \\
\hline 14 & 10,4 & 10,5 & 10,1 & 10,3 & 0,2 \\
\hline 15 & 13,1 & 11,8 & 11,7 & 12,2 & 0,8 \\
\hline 16 & 11,7 & 11,3 & 11,4 & 11,5 & 0,2 \\
\hline 17 & 9,6 & 9,8 & 9,2 & 9,5 & 0,3 \\
\hline 18 & 6,2 & 6,5 & 5,7 & 6,1 & 0,4 \\
\hline \multirow[t]{2}{*}{$\mathrm{R} 2$} & $\mathrm{~F} 2$ & & $\begin{array}{c}\text { Média } \\
\left(\mu \mathrm{W} / \mathrm{cm}^{2} \mathrm{~nm}\right)\end{array}$ & 10,7 & \\
\hline & & & $\begin{array}{c}\text { Desvio padrão } \\
\left(\mu \mathrm{W} / \mathrm{cm}^{2} \mathrm{~nm}\right)\end{array}$ & 2,8 & \\
\hline
\end{tabular}


Tabela A7 - Valores de irradiâncias eficazes (unidades em $\mu \mathrm{W} / \mathrm{cm}^{2}$ ) de três medições $(L 1$, L2 e L3), efetuadas com o radiômetro ER a $45 \mathrm{~cm}$ da fonte $\mathrm{H} 1$, nos pontos 1 a 24 distribuídos na superfície elíptica descritos na FIG. 5.5, onde cada setor da elipse recebe a potência calculada a partir da irradiância eficaz e área correspondente.

\begin{tabular}{|c|c|c|c|c|c|c|c|}
\hline \multicolumn{8}{|c|}{ Unidade de fototerapia H1 - Espectro-radiômetro ER } \\
\hline Ponto & $\begin{array}{c}\mathrm{L1} \\
\left(\mu \mathrm{W} / \mathrm{cm}^{2}\right)\end{array}$ & $\begin{array}{c}\mathrm{L} 2 \\
\left(\mu \mathrm{W} / \mathrm{cm}^{2}\right)\end{array}$ & $\begin{array}{c}\text { L3 } \\
\left(\mu \mathrm{W} / \mathrm{cm}^{2}\right)\end{array}$ & $\begin{array}{c}\text { Média } \\
\left(\mu \mathrm{W} / \mathrm{cm}^{2}\right)\end{array}$ & $\begin{array}{c}\text { Desvio padrão } \\
\left(\mu \mathrm{W} / \mathrm{cm}^{2}\right)\end{array}$ & $\begin{array}{l}\text { Área } \\
(\mathrm{cm} 2)\end{array}$ & $\begin{array}{c}\text { Potencia } \\
(\mu \mathrm{W})\end{array}$ \\
\hline 1 & 734 & 794 & 808 & 778,7 & 39 & 12,1 & 9383 \\
\hline 2 & 2593 & 2652 & 2842 & 2696 & 130 & 7,2 & 19491 \\
\hline 3 & 3078 & 3086 & 3166 & 3110 & 49 & 2,4 & 7494 \\
\hline 4 & 1031 & 1089 & 1089 & 1070 & 33 & 2,4 & 2578 \\
\hline 5 & 362 & 342 & 369 & 358 & 14 & 7,2 & 2585 \\
\hline 6 & 135 & 135 & 148 & 140 & 8 & 12,1 & 1681 \\
\hline 7 & 405 & 420 & 436 & 420 & 16 & 13,6 & 5732 \\
\hline 8 & 1134 & 1252 & 1278 & 1222 & 77 & 6,0 & 7379 \\
\hline 9 & 2357 & 2353 & 2411 & 2374 & 33 & 2,0 & 4771 \\
\hline 10 & 1594 & 1500 & 1589 & 1561 & 53 & 2,0 & 3138 \\
\hline 11 & 628 & 570 & 623 & 607 & 32 & 6,0 & 3665 \\
\hline 12 & 229 & 207 & 232 & 223 & 14 & 13,6 & 3039 \\
\hline 13 & 184 & 174 & 195 & 184 & 11 & 8,1 & 1487 \\
\hline 14 & 536 & 534 & 533 & 534 & 2 & 4,8 & 2586 \\
\hline 15 & 1491 & 1423 & 1374 & 1430 & 59 & 1,6 & 2302 \\
\hline 16 & 2407 & 2246 & 2219 & 2291 & 102 & 1,6 & 3688 \\
\hline 17 & 1352 & 1135 & 1248 & 1245 & 109 & 4,8 & 6026 \\
\hline 18 & 630 & 515 & 579 & 574 & 57 & 8,1 & 4635 \\
\hline 19 & 140 & 134 & 132 & 135 & 4 & 10,1 & 1361 \\
\hline 20 & 370 & 357 & 338 & 355 & 17 & 6,0 & 2145 \\
\hline 21 & 1266 & 1173 & 1161 & 1200 & 57 & 2,0 & 2412 \\
\hline 22 & 3144 & 3052 & 2804 & 3000 & 176 & 2,0 & 6030 \\
\hline 23 & 2756 & 2619 & 2488 & 2621 & 134 & 6,0 & 15830 \\
\hline \multirow[t]{4}{*}{24} & 1083 & 1048 & 999 & 1044 & 42 & 4,4 & 4560 \\
\hline & & & $\begin{array}{c}\text { Média } \\
\left(\mu \mathrm{W} / \mathrm{cm}^{2}\right) \\
\end{array}$ & 1215 & - & $\begin{array}{c}\Sigma \mathrm{A} \\
\left(\mathrm{cm}^{2}\right)\end{array}$ & $\begin{array}{c}\sum \mathrm{P} \\
(\mu \mathrm{W})\end{array}$ \\
\hline & & & $\begin{array}{r}\text { Desvio } \\
\text { Padrão } \\
\left(\mu \mathrm{W} / \mathrm{cm}^{2}\right) \\
\end{array}$ & 968 & - & 146,3 & 124000 \\
\hline & & & $\begin{array}{c}\sum \mathrm{A} / \Sigma \mathrm{P} \\
\left(\mu \mathrm{W} / \mathrm{cm}^{2}\right) \\
\end{array}$ & 848 & & & \\
\hline
\end{tabular}


Tabela A8 - Valores de irradiâncias espectrais eficazes (unidades em $\mu \mathrm{W} / \mathrm{cm}^{2} \mathrm{~nm}$ ) de três medições (L1, L2 e L3), efetuadas com o radiômetro R1 a $45 \mathrm{~cm}$ da fonte H1, nos pontos 1 a 24 distribuídos na superfície elíptica descritos na FIG. 5.5, onde cada setor da elipse recebe a potência calculada a partir da irradiância eficaz e área correspondente.

\begin{tabular}{|c|c|c|c|c|c|c|c|}
\hline \multicolumn{8}{|c|}{ Unidade de fototerapia H1 - Radiômetro R1 } \\
\hline Ponto & $\begin{array}{c}\mathrm{L} 1 \\
\left(\mu \mathrm{W} / \mathrm{cm}^{2}\right)\end{array}$ & $\begin{array}{c}\mathrm{L} 2 \\
\left(\mu \mathrm{W} / \mathrm{cm}^{2}\right)\end{array}$ & $\begin{array}{c}\mathrm{L3} \\
\left(\mu \mathrm{W} / \mathrm{cm}^{2}\right)\end{array}$ & $\begin{array}{c}\text { Média } \\
\left(\mu \mathrm{W} / \mathrm{cm}^{2}\right)\end{array}$ & $\begin{array}{c}\text { Desvio padrão } \\
\left(\mu \mathrm{W} / \mathrm{cm}^{2}\right)\end{array}$ & $\begin{array}{l}\text { Área } \\
\text { (cm2) }\end{array}$ & $\begin{array}{l}\text { Potencia } \\
(\mu \mathrm{W} / \mathrm{nm})\end{array}$ \\
\hline 1 & 5,6 & 5,8 & 5,2 & 5,5 & 0,3 & 12,1 & 66,3 \\
\hline 2 & 18,2 & 18,4 & 18,1 & 18,2 & 0,2 & 7,2 & 131,7 \\
\hline 3 & 25,1 & 25,7 & 25,4 & 25,4 & 0,3 & 2,4 & 61,2 \\
\hline 4 & 8,8 & 7,8 & 7,8 & 8,1 & 0,6 & 2,4 & 19,5 \\
\hline 5 & 2,5 & 3,2 & 3 & 2,9 & 0,4 & 7,2 & 21,0 \\
\hline 6 & 0,8 & 1,1 & 0,8 & 0,9 & 0,2 & 12,1 & 10,8 \\
\hline 7 & 3 & 3,1 & 3,4 & 3,2 & 0,2 & 13,6 & 43,2 \\
\hline 8 & 9,3 & 8,6 & 8,4 & 8,8 & 0,4 & 6,0 & 52,9 \\
\hline 9 & 17,9 & 16,2 & 17,8 & 17,3 & 0,9 & 2,0 & 34,7 \\
\hline 10 & 14 & 13,1 & 14,6 & 13,9 & 0,8 & 2,0 & 27,9 \\
\hline 11 & 5,2 & 6 & 5,3 & 5,5 & 0,5 & 6,0 & 33,0 \\
\hline 12 & 1,6 & 2,1 & 1,9 & 1,9 & 0,2 & 13,6 & 25,4 \\
\hline 13 & 1,4 & 1,1 & 1,3 & 1,3 & 0,5 & 8,1 & 10,5 \\
\hline 14 & 3,5 & 3,8 & 3,3 & 3,5 & 0,3 & 4,8 & 17,1 \\
\hline 15 & 11,3 & 10,8 & 12,1 & 11,4 & 0,7 & 1,6 & 18,3 \\
\hline 16 & 19,6 & 19,8 & 21 & 20,1 & 0,8 & 1,6 & 32,4 \\
\hline 17 & 15,3 & 14,1 & 13,8 & 14,4 & 0,8 & 4,8 & 69,5 \\
\hline 18 & 4,3 & 5,6 & 5,6 & 5,2 & 0,8 & 8,1 & 41,7 \\
\hline 19 & 0,7 & 0,8 & 0,8 & 0,8 & 0,1 & 10,1 & 7,6 \\
\hline 20 & 2,4 & 3 & 2,8 & 2,7 & 0,3 & 6,0 & 16,4 \\
\hline 21 & 9,1 & 9,6 & 9,3 & 9,3 & 0,3 & 2,0 & 18,7 \\
\hline 22 & 24,6 & 23,5 & 24,5 & 24,2 & 0,6 & 2,0 & 48,6 \\
\hline 23 & 21,9 & 20,8 & 22,9 & 21,9 & 1,1 & 6,0 & 132,1 \\
\hline \multirow[t]{4}{*}{24} & 8,9 & 10,5 & 10,2 & 9,8 & 0,8 & 4,4 & 43,0 \\
\hline & & & $\begin{array}{c}\text { Média } \\
\left(\mu \mathrm{W} / \mathrm{cm}^{2}\right)\end{array}$ & 9,8 & - & $\begin{aligned} \Sigma A \\
\left(\mathrm{~cm}^{2}\right)\end{aligned}$ & $\begin{array}{c}\sum P \\
(\mu W . n m) I\end{array}$ \\
\hline & & & $\begin{array}{c}\text { Desvio } \\
\text { Padrão } \\
\left(\mu \mathrm{W} / \mathrm{cm}^{2}\right)\end{array}$ & 7,8 & - & 146,3 & 983,6 \\
\hline & & & $\begin{array}{c}\Sigma \mathrm{A} / \Sigma \mathrm{P} \\
\left(\mu \mathrm{W} / \mathrm{cm}^{2}\right)\end{array}$ & 6,7 & & & \\
\hline
\end{tabular}


Tabela A9 - Valores de irradiâncias espectrais eficazes (unidades em $\mu \mathrm{W} / \mathrm{cm}^{2} \mathrm{~nm}$ ) de três medições (L1, L2 e L3), efetuadas com o radiômetro R2 a $45 \mathrm{~cm}$ da fonte H1, nos pontos 1 a 24 distribuídos na superfície elíptica descritos na FIG. 5.5, onde cada setor da elipse recebe a potência calculada a partir da irradiância eficaz e área correspondente.

\begin{tabular}{|c|c|c|c|c|c|c|c|}
\hline \multicolumn{8}{|c|}{ Unidade de fototerapia H1 - Radiômetro R2 } \\
\hline Ponto & $\begin{array}{c}\mathrm{L} 1 \\
\left(\mu \mathrm{W} / \mathrm{cm}^{2}\right) \\
\end{array}$ & $\begin{array}{c}\mathrm{L} 2 \\
\left(\mu \mathrm{W} / \mathrm{cm}^{2}\right) \\
\end{array}$ & $\begin{array}{c}\mathrm{L3} \\
\left(\mu \mathrm{W} / \mathrm{cm}^{2}\right) \\
\end{array}$ & $\begin{array}{c}\text { Média } \\
\left(\mu \mathrm{W} / \mathrm{cm}^{2}\right) \\
\end{array}$ & $\begin{array}{c}\text { Desvio padrão } \\
\left(\mu \mathrm{W} / \mathrm{cm}^{2}\right)\end{array}$ & $\begin{array}{c}\text { Área } \\
(\mathrm{cm} 2)\end{array}$ & $\begin{array}{l}\text { Potencia } \\
(\mu \mathrm{W} / \mathrm{nm}) \\
\end{array}$ \\
\hline 1 & 3,4 & 3,5 & 3,1 & 3,3 & 0,2 & 12,1 & 39,8 \\
\hline 2 & 8,4 & 9,4 & 8,4 & 8,7 & 0,6 & 7,2 & 62,2 \\
\hline 3 & 10,0 & 10,0 & 9,9 & 10,0 & 0,0 & 2,4 & 24,1 \\
\hline 4 & 3,6 & 4,1 & 3,5 & 3,7 & 0,3 & 2,4 & 8,8 \\
\hline 5 & 1,3 & 0,9 & 1,1 & 1,1 & 0,2 & 7,2 & 8,0 \\
\hline 6 & 0,1 & 0,1 & 0,1 & 0,1 & 0,0 & 12,1 & 1,5 \\
\hline 7 & 2,2 & 2,9 & 2,2 & 2,4 & 0,4 & 13,6 & 31,9 \\
\hline 8 & 4,8 & 6,4 & 5 & 5,4 & 0,9 & 6,0 & 31,4 \\
\hline 9 & 9,4 & 8,6 & 8,2 & 8,8 & 0,6 & 2,0 & 17,7 \\
\hline 10 & 4,6 & 4,9 & 4,5 & 4,6 & 0,2 & 2,0 & 9,3 \\
\hline 11 & 1,8 & 1,7 & 1,6 & 1,7 & 0,1 & 6,0 & 10,3 \\
\hline 12 & 0,3 & 0,4 & 0,3 & 0,3 & 0,1 & 13,6 & 4,6 \\
\hline 13 & 0,5 & 0,5 & 0,5 & 0,5 & 0,0 & 8,1 & 3,9 \\
\hline 14 & 1,8 & 2,3 & 1,6 & 1,9 & 0,4 & 4,8 & 8,7 \\
\hline 15 & 5 & 5,5 & 6,2 & 5,5 & 0,6 & 1,6 & 9,0 \\
\hline 16 & 7,2 & 7,5 & 7,5 & 7,3 & 0,2 & 1,6 & 11,9 \\
\hline 17 & 3,9 & 3,7 & 4,0 & 3,9 & 0,2 & 4,8 & 19,0 \\
\hline 18 & 1,4 & 1,2 & 1,8 & 1,5 & 0,3 & 8,1 & 28,3 \\
\hline 19 & 0,3 & 0,2 & 0,1 & 0,2 & 0,1 & 10,1 & 2,0 \\
\hline 20 & 0,8 & 1,2 & 1,1 & 1,1 & 0,2 & 6,0 & 6,3 \\
\hline 21 & 5 & 5,5 & 4,3 & 4,9 & 0,6 & 2,0 & 9,7 \\
\hline 22 & 11,9 & 11,7 & 12,2 & 12 & 0,3 & 2,0 & 24,1 \\
\hline 23 & 12,2 & 10,9 & 12,0 & 11,7 & 0,7 & 6,0 & 71,6 \\
\hline \multirow[t]{4}{*}{24} & 4,8 & 4,2 & 5,1 & 4,7 & 0,5 & 4,4 & 48,3 \\
\hline & & & $\begin{array}{c}\text { Média } \\
\left(\mu \mathrm{W} / \mathrm{cm}^{2} \mathrm{~nm}\right) \\
\end{array}$ & 4,4 & - & $\begin{array}{c}\Sigma \mathrm{A} \\
\left(\mathrm{cm}^{2}\right)\end{array}$ & $\begin{array}{c}\sum \mathrm{P} \\
(\mu \mathrm{W} . \mathrm{nm}) \mid\end{array}$ \\
\hline & & & $\begin{array}{c}\text { Desvio } \\
\text { Padrão } \\
\left(\mu \mathrm{W} / \mathrm{cm}^{2} \cdot \mathrm{nm}\right)\end{array}$ & 3,7 & - & 146,1 & 492,1 \\
\hline & & & $\begin{array}{c}\Sigma \mathrm{A} / \Sigma \mathrm{P} \\
\left(\mu \mathrm{W} / \mathrm{cm}^{2} \mathrm{~nm}\right)\end{array}$ & 3,4 & & & \\
\hline
\end{tabular}


Tabela A10 - Valores de irradiâncias eficazes (unidades em $\mu \mathrm{W} / \mathrm{cm}^{2}$ ) de três medições ( $L 1$, L2 e L3), efetuadas com o radiômetro ER a $45 \mathrm{~cm}$ da fonte $\mathrm{H} 2$, nos pontos 1 a 24 distribuídos na superfície elíptica descritos na FIG. 5.5, onde cada setor da elipse recebe a potência calculada a partir da irradiância eficaz e área correspondente.

\begin{tabular}{|c|c|c|c|c|c|c|c|}
\hline \multicolumn{8}{|c|}{ Unidade de fototerapia H2 - Espectro-radiômetro ER } \\
\hline Ponto & $\begin{array}{c}\mathrm{L} 1 \\
\left(\mu \mathrm{W} / \mathrm{cm}^{2}\right)\end{array}$ & $\begin{array}{c}\mathrm{L} 2 \\
\left(\mu \mathrm{W} / \mathrm{cm}^{2}\right)\end{array}$ & $\begin{array}{c}\text { L3 } \\
\left(\mu \mathrm{W} / \mathrm{cm}^{2}\right)\end{array}$ & $\begin{array}{c}\text { Média } \\
\left(\mu \mathrm{W} / \mathrm{cm}^{2}\right)\end{array}$ & $\begin{array}{c}\text { Desvio padrão } \\
\left(\mu \mathrm{W} / \mathrm{cm}^{2}\right)\end{array}$ & $\begin{array}{l}\text { Área } \\
(\mathrm{cm} 2)\end{array}$ & $\begin{array}{c}\text { Potencia } \\
(\mu \mathrm{W})\end{array}$ \\
\hline 1 & 530 & 640 & 660 & 610 & 70 & 17,3 & 10548 \\
\hline 2 & 1643 & 1424 & 1574 & 1547 & 112 & 10,1 & 15623 \\
\hline 3 & 1359 & 1215 & 1228 & 1267 & 79 & 3,4 & 4309 \\
\hline 4 & 1007 & 838 & 977 & 941 & 90 & 3,4 & 3198 \\
\hline 5 & 369 & 286 & 369 & 342 & 48 & 10,1 & 3449 \\
\hline 6 & 129 & 89 & 128 & 116 & 23 & 17,3 & 1996 \\
\hline 7 & 476 & 444 & 498 & 473 & 27 & 20,0 & 9452 \\
\hline 8 & 1417 & 1365 & 1373 & 1385 & 28 & 8,1 & 11218 \\
\hline 9 & 1356 & 1302 & 1242 & 1300 & 57 & 2,7 & 3509 \\
\hline 10 & 1070 & 1092 & 1109 & 1090 & 20 & 2,7 & 2944 \\
\hline 11 & 547 & 486 & 465 & 499 & 43 & 8,1 & 4044 \\
\hline 12 & 186 & 140 & 190 & 172 & 28 & 20,0 & 3442 \\
\hline 13 & 257 & 196 & 224 & 226 & 30 & 9,8 & 2213 \\
\hline 14 & 849 & 781 & 751 & 794 & 50 & 6,1 & 4842 \\
\hline 15 & 1308 & 1145 & 1217 & 1223 & 82 & 2,0 & 2447 \\
\hline 16 & 1268 & 1145 & 1208 & 1207 & 62 & 2,0 & 2415 \\
\hline 17 & 838 & 893 & 813 & 848 & 41 & 6,1 & 5173 \\
\hline 18 & 329 & 360 & 306 & 332 & 27 & 9,8 & 3251 \\
\hline 19 & 166 & 148 & 129 & 148 & 18 & 13,5 & 1993 \\
\hline 20 & 492 & 604 & 459 & 518 & 76 & 8,1 & 4197 \\
\hline 21 & 934 & 955 & 1110 & 1000 & 96 & 2,7 & 2700 \\
\hline 22 & 1232 & 1296 & 1365 & 1298 & 67 & 2,7 & 3504 \\
\hline 23 & 1166 & 1225 & 744 & 1045 & 262 & 8,1 & 8467 \\
\hline \multirow[t]{4}{*}{24} & 511 & 292 & 264 & 356 & 135 & 13,5 & 4802 \\
\hline & & & $\begin{array}{c}\text { Média } \\
\left(\mu \mathrm{W} / \mathrm{cm}^{2}\right)\end{array}$ & 781 & - & $\begin{array}{c}\Sigma \mathrm{A} \\
\left(\mathrm{cm}^{2}\right)\end{array}$ & $\begin{array}{c}\sum \mathrm{P} \\
(\mu \mathrm{W}) !\end{array}$ \\
\hline & & & $\begin{array}{c}\text { Desvio } \\
\text { Padrão } \\
\left(\mu \mathrm{W} / \mathrm{cm}^{2}\right)\end{array}$ & 453 & - & 207,6 & 119734 \\
\hline & & & $\begin{array}{c}\Sigma \mathrm{A} / \Sigma \mathrm{P} \\
\left(\mu \mathrm{W} / \mathrm{cm}^{2}\right)\end{array}$ & 577 & & & \\
\hline
\end{tabular}


Tabela A11 - Valores de irradiâncias espectrais eficazes (unidades em $\mu \mathrm{W} / \mathrm{cm}^{2} \mathrm{~nm}$ ) de três medições (L1, L2 e L3), efetuadas com o radiômetro R1 a $45 \mathrm{~cm}$ da fonte $H 2$, nos pontos 1 a 24 distribuídos na superfície elíptica descritos na FIG. 5.5, onde cada setor da elipse recebe a potência calculada a partir da irradiância eficaz e área correspondente.

\begin{tabular}{|c|c|c|c|c|c|c|c|}
\hline \multicolumn{8}{|c|}{ Unidade de fototerapia H2 - Radiômetro R1 } \\
\hline Ponto & $\begin{array}{c}\mathrm{L} 1 \\
\left(\mu \mathrm{W} / \mathrm{cm}^{2}\right)\end{array}$ & $\begin{array}{c}\mathrm{L} 2 \\
\left(\mu \mathrm{W} / \mathrm{cm}^{2}\right)\end{array}$ & $\begin{array}{c}\text { L3 } \\
\left(\mu \mathrm{W} / \mathrm{cm}^{2}\right)\end{array}$ & $\begin{array}{c}\text { Média } \\
\left(\mu \mathrm{W} / \mathrm{cm}^{2}\right)\end{array}$ & $\begin{array}{c}\text { Desvio padrão } \\
\left(\mu \mathrm{W} / \mathrm{cm}^{2}\right)\end{array}$ & $\begin{array}{c}\text { Área (A) } \\
\text { (cm2) }\end{array}$ & $\begin{array}{l}\text { Potencia (P) } \\
(\mu \mathrm{W} / \mathrm{nm})\end{array}$ \\
\hline 1 & 3,5 & 2,8 & 3,6 & 3,3 & 0,5 & 17,3 & 57,1 \\
\hline 2 & 10,8 & 11,7 & 11,1 & 11,2 & 0,5 & 10,1 & 113,1 \\
\hline 3 & 9,8 & 9,9 & 11,2 & 10,3 & 0,8 & 3,4 & 35,0 \\
\hline 4 & 7,0 & 7,4 & 7,2 & 7,2 & 0,2 & 3,4 & 24,5 \\
\hline 5 & 3,4 & 4,1 & 3,2 & 3,5 & 0,5 & 10,1 & 35,4 \\
\hline 6 & 1,1 & 1,0 & 0,9 & 1,0 & 0,1 & 17,3 & 17,3 \\
\hline 7 & 1,9 & 1,6 & 1,7 & 1,7 & 0,1 & 20,0 & 34,0 \\
\hline 8 & 7,3 & 6,9 & 8,1 & 7,4 & 0,6 & 8,1 & 59,9 \\
\hline 9 & 9,1 & 9,0 & 9,6 & 9,2 & 0,3 & 2,7 & 24,8 \\
\hline 10 & 7,8 & 8,0 & 8,1 & 8,0 & 0,2 & 2,7 & 21,6 \\
\hline 11 & 5,2 & 5,3 & 5,1 & 5,2 & 0,1 & 8,1 & 42,1 \\
\hline 12 & 1,6 & 1,6 & 1,8 & 1,7 & 0,1 & 20,0 & 34,0 \\
\hline 13 & 1,3 & 1,3 & 1,4 & 1,3 & 0,1 & 9,8 & 12,7 \\
\hline 14 & 5,7 & 5,8 & 5,0 & 5,5 & 0,4 & 6,1 & 33,5 \\
\hline 15 & 8,3 & 8,6 & 8,9 & 8,6 & 0,3 & 2,0 & 17,2 \\
\hline 16 & 8,0 & 8,4 & 8,2 & 8,2 & 0,2 & 2,0 & 16,4 \\
\hline 17 & 7,1 & 7,0 & 7,2 & 7,1 & 0,1 & 6,1 & 43,3 \\
\hline 18 & 2,5 & 2,1 & 1,8 & 2,1 & 0,3 & 9,8 & 20,6 \\
\hline 19 & 1,3 & 1,3 & 1,3 & 1,3 & 0,0 & 13,5 & 17,6 \\
\hline 20 & 4,3 & 3,9 & 3,8 & 4,0 & 0,2 & 8,1 & 32,4 \\
\hline 21 & 7,2 & 7,3 & 7,2 & 7,2 & 0 & 2,7 & 19,4 \\
\hline 22 & 8,2 & 8,6 & 8,9 & 8,6 & 0,4 & 2,7 & 23,2 \\
\hline 23 & 8,3 & 8,4 & 9,2 & 8,7 & 0,5 & 8,1 & 70,5 \\
\hline \multirow[t]{4}{*}{24} & 2,9 & 3,6 & 3,6 & 3,4 & 0,4 & 13,5 & 45,9 \\
\hline & & & $\begin{array}{c}\text { Média } \\
\left(\mu \mathrm{W} / \mathrm{cm}^{2} \mathrm{~nm}\right)\end{array}$ & 5,7 & - & $\begin{array}{c}\sum \mathrm{A} \\
\left(\mathrm{cm}^{2}\right)\end{array}$ & $\begin{array}{c}\sum \mathrm{P} \\
(\mu \mathrm{W} \cdot \mathrm{nm}) \mathrm{I}\end{array}$ \\
\hline & & & $\begin{array}{c}\text { Desvio } \\
\text { Padrão } \\
\left(\mu \mathrm{W} / \mathrm{cm}^{2} \mathrm{~nm}\right) \\
\end{array}$ & 3,2 & - & 207,6 & 851,6 \\
\hline & & & $\begin{array}{c}\sum \mathrm{A} / \Sigma \mathrm{P} \\
\left(\mu \mathrm{W} / \mathrm{cm}^{2} \mathrm{~nm}\right)\end{array}$ & 4,1 & & & \\
\hline
\end{tabular}


Tabela A12 - Valores de irradiâncias espectrais eficazes (unidades em $\mu \mathrm{W} / \mathrm{cm}^{2} \mathrm{~nm}$ ) de três medições (L1, L2 e L3), efetuadas com o radiômetro R2 a $45 \mathrm{~cm}$ da fonte $H 2$, nos pontos 1 a 24 distribuídos na superfície elíptica descritos na FIG. 5.5, onde cada setor da elipse recebe a potência calculada a partir da irradiância eficaz e área correspondente.

\begin{tabular}{|c|c|c|c|c|c|c|c|}
\hline \multicolumn{8}{|c|}{ Unidade de fototerapia H2 - Radiômetro R2 } \\
\hline Ponto & $\begin{array}{c}\mathrm{L1} \\
\left(\mu \mathrm{W} / \mathrm{cm}^{2} \mathrm{~nm}\right)\end{array}$ & $\begin{array}{c}\mathrm{L} 2 \\
\left(\mu \mathrm{W} / \mathrm{cm}^{2} \mathrm{~nm}\right)\end{array}$ & $\begin{array}{c}\mathrm{L3} \\
\left(\mu \mathrm{W} / \mathrm{cm}^{2} \mathrm{~nm}\right)\end{array}$ & Média & $\begin{array}{c}\text { Desvio padrão } \\
\left(\mu \mathrm{W} / \mathrm{cm}^{2} \mathrm{~nm}\right)\end{array}$ & $\begin{array}{l}\text { Área } \\
(\mathrm{cm} 2)\end{array}$ & $\begin{array}{l}\text { Potencia } \\
(\mu \mathrm{W} / \mathrm{nm})\end{array}$ \\
\hline 1 & 3,7 & 4,0 & 4,5 & 4,1 & 0,4 & 17,3 & 70,9 \\
\hline 2 & 6,6 & 7,0 & 5,5 & 6,4 & 0,8 & 10,1 & 64,6 \\
\hline 3 & 4,3 & 4,0 & 3,8 & 4,0 & 0,3 & 3,4 & 13,6 \\
\hline 4 & 2,0 & 2,0 & 2,1 & 2,1 & 0,1 & 3,4 & 7,1 \\
\hline 5 & 0,7 & 0,8 & 0,8 & 0,8 & 0,1 & 10,1 & 8,1 \\
\hline 6 & 0,0 & 0,0 & 0,0 & 0,0 & 0,0 & 17,3 & 0,0 \\
\hline 7 & 1,2 & 0,9 & 1,5 & 1,2 & 0,3 & 20,0 & 24 \\
\hline 8 & 4,0 & 4,0 & 3,8 & 3,9 & 0,1 & 8,1 & 31,6 \\
\hline 9 & 3,7 & 3,8 & 3,6 & 3,7 & 0,1 & 2,7 & 10,0 \\
\hline 10 & 2,5 & 2,5 & 2,7 & 2,6 & 0,1 & 2,7 & 7,0 \\
\hline 11 & 0,8 & 0,8 & 1,1 & 0,9 & 0,2 & 8,1 & 7,3 \\
\hline 12 & 0,1 & 0,1 & 0,1 & 0,1 & 0,0 & 20,0 & 2,0 \\
\hline 13 & 0,4 & 0,5 & 0,3 & 0,4 & 0,1 & 9,8 & 3,9 \\
\hline 14 & 1,7 & 2,0 & 1,9 & 1,9 & 0,1 & 6,1 & 11,6 \\
\hline 15 & 3,5 & 3,3 & 2,9 & 3,2 & 0,3 & 2,0 & 6,4 \\
\hline 16 & 3,1 & 3,4 & 3,4 & 3,3 & 0,1 & 2,0 & 6,6 \\
\hline 17 & 2,1 & 2,0 & 2,4 & 2,2 & 0,2 & 6,1 & 13,4 \\
\hline 18 & 0,6 & 0,1 & 0,8 & 0,5 & 0,4 & 9,8 & 4,9 \\
\hline 19 & 0,1 & 0,1 & 0,1 & 0,1 & 0,0 & 13,5 & 1,4 \\
\hline 20 & 0,7 & 0,7 & 0,8 & 0,7 & 0,0 & 8,1 & 5,7 \\
\hline 21 & 2,7 & 2,8 & 2,9 & 2,8 & 0,1 & 2,7 & 7,6 \\
\hline 22 & 3,7 & 3,8 & 3,8 & 3,8 & 0,1 & 2,7 & 10,3 \\
\hline 23 & 3,9 & 4,5 & 4,7 & 4,4 & 0,4 & 8,1 & 35,6 \\
\hline \multirow[t]{4}{*}{24} & 1,7 & 2,0 & 2,4 & 2,0 & 0,4 & 13,5 & 27,0 \\
\hline & & & $\begin{array}{c}\text { Média } \\
\left(\mu \mathrm{W} / \mathrm{cm}^{2} \mathrm{~nm}\right)\end{array}$ & 2,3 & - & $\begin{array}{c}\Sigma \mathrm{A} \\
\left(\mathrm{cm}^{2}\right)\end{array}$ & $\begin{array}{c}\sum \mathrm{P} \\
(\mu \mathrm{W} \cdot \mathrm{nm}) \mathrm{I}\end{array}$ \\
\hline & & & $\begin{array}{c}\text { Desvio } \\
\text { Padrão } \\
\left(\mu \mathrm{W} / \mathrm{cm}^{2}{ }^{2} \mathrm{~m}\right) \\
\end{array}$ & 1,7 & - & 207,6 & 380,6 \\
\hline & & & $\begin{array}{c}\sum \mathrm{A} / \Sigma \mathrm{P} \\
\left(\mu \mathrm{W} / \mathrm{cm}^{2} \mathrm{~nm}\right)\end{array}$ & 1,8 & & & \\
\hline
\end{tabular}


ANEXO B

Tabela B1 - Valores de irradiâncias $\left(\mu \mathrm{W} / \mathrm{cm}^{2}\right)$, Irradiâncias espectrais eficazes (unidades em $\mu \mathrm{W} / \mathrm{cm}^{2} \mathrm{~nm}$ ), irradiâcias eficazes corrigidas $\left(\mu \mathrm{W} / \mathrm{cm}^{2}\right)$ e o erro (\%), efetuados com o radiômetro R1 e R2 a $25 \mathrm{~cm}$ da fonte $\mathrm{F} 1$, nos pontos 1 a 18 distribuídos na superfície efetiva descritos na FIG. 5.2,

\begin{tabular}{|c|c|c|c|c|c|c|c|c|c|}
\hline $\mathrm{F} 1$ & $\begin{array}{l}\text { Irradiância } \\
\text { Eficaz }\end{array}$ & $\begin{array}{c}\text { Irradiância } \\
\text { Espectral } \\
\text { Eficaz } \\
\end{array}$ & $\begin{array}{l}\text { Irradiância } \\
\text { Eficaz }\end{array}$ & Erro & & $\begin{array}{c}\text { Irradiância } \\
\text { Espectral } \\
\text { Eficaz }\end{array}$ & $\begin{array}{l}\text { Irradiância } \\
\text { Eficaz }\end{array}$ & Erro & \\
\hline Ponto & $\begin{array}{c}\mathrm{E}_{\mathrm{DIN}} \\
\left(\mu \mathrm{W} / \mathrm{cm}^{2}\right)\end{array}$ & $\begin{array}{c}\mathrm{R} 1 \\
\left(\mu \mathrm{W} / \mathrm{cm}^{2} \mathrm{~nm}\right)\end{array}$ & $\begin{array}{c}\mathrm{R} 1 \mathrm{C} \\
\mu \mathrm{W} / \mathrm{nm}\end{array}$ & $\left(\frac{R 1 C-E_{D I N}}{E_{D I N}}\right.$ & $\cdot 100$ & $\begin{array}{c}\mathrm{R} 2 \\
\left(\mu \mathrm{W} / \mathrm{cm}^{2} \mathrm{~nm}\right)\end{array}$ & $\begin{array}{c}\mathrm{R} 2 \mathrm{C} \\
\mu \mathrm{W} / \mathrm{nm}\end{array}$ & $\left(\frac{R 2 C-E_{D I N}}{E_{D I N}}\right.$ & $\cdot 100$ \\
\hline 1 & 743 & 6,1 & 562 & \multicolumn{2}{|l|}{$-24,4$} & 5,3 & 547 & \multicolumn{2}{|l|}{$-26,4$} \\
\hline 2 & 1002 & 9,8 & 903 & \multicolumn{2}{|l|}{$-9,9$} & 9,2 & 949 & \multicolumn{2}{|l|}{$-5,2$} \\
\hline 3 & 1061 & 11,7 & 1078 & \multicolumn{2}{|l|}{1,6} & 10,3 & 1063 & \multicolumn{2}{|l|}{0,2} \\
\hline 4 & 1052 & 11,9 & 1096 & \multicolumn{2}{|l|}{4,2} & 10,6 & 1093 & \multicolumn{2}{|l|}{4,0} \\
\hline 5 & 1062 & 10,8 & 995 & \multicolumn{2}{|l|}{$-6,3$} & 8,5 & 877 & \multicolumn{2}{|l|}{$-17,4$} \\
\hline 6 & 701 & 7,4 & 682 & \multicolumn{2}{|l|}{$-2,7$} & 5,6 & 578 & \multicolumn{2}{|l|}{$-17,6$} \\
\hline 7 & 817 & 7,6 & 700 & \multicolumn{2}{|l|}{$-14,3$} & 7,1 & 733 & \multicolumn{2}{|l|}{$-10,3$} \\
\hline 8 & 1246 & 11,7 & 1078 & \multicolumn{2}{|l|}{$-13,5$} & 11,3 & 1166 & \multicolumn{2}{|l|}{$-6,4$} \\
\hline 9 & 1188 & 13,7 & 1262 & \multicolumn{2}{|l|}{6,3} & 12,4 & 1280 & \multicolumn{2}{|l|}{7,7} \\
\hline 10 & 1290 & 14,0 & 1290 & \multicolumn{2}{|l|}{0,0} & 12,5 & 1290 & \multicolumn{2}{|l|}{0,0} \\
\hline 11 & 1116 & 12,6 & 1161 & \multicolumn{2}{|l|}{4,0} & 10,3 & 1063 & \multicolumn{2}{|l|}{$-4,8$} \\
\hline 12 & 817 & 8,4 & 774 & \multicolumn{2}{|l|}{$-5,3$} & 6,3 & 650 & \multicolumn{2}{|l|}{$-20,4$} \\
\hline 13 & 726 & 6,2 & 571 & \multicolumn{2}{|l|}{$-21,3$} & 6,2 & 640 & \multicolumn{2}{|l|}{$-11,9$} \\
\hline 14 & 936 & 9,9 & 912 & \multicolumn{2}{|l|}{$-2,5$} & 9,0 & 929 & \multicolumn{2}{|l|}{$-0,8$} \\
\hline 15 & 1132 & 11,4 & 1050 & \multicolumn{2}{|l|}{$-7,2$} & 10,0 & 1032 & \multicolumn{2}{|l|}{$-8,8$} \\
\hline 16 & 1183 & 11,3 & 1041 & \multicolumn{2}{|l|}{-12} & 9,8 & 1011 & \multicolumn{2}{|l|}{$-14,5$} \\
\hline 17 & 932 & 10,5 & 968 & \multicolumn{2}{|l|}{3,8} & 7,8 & 805 & \multicolumn{2}{|l|}{$-13,6$} \\
\hline 18 & 664 & 6,8 & 627 & $-5,6$ & & 4,9 & 506 & $-23,8$ & \\
\hline
\end{tabular}


Tabela B2 - Valores de irradiâncias $\left(\mu \mathrm{W} / \mathrm{cm}^{2}\right)$, Irradiâncias espectrais eficazes (unidades em $\mu \mathrm{W} / \mathrm{cm}^{2} \mathrm{~nm}$ ), irradiâcias eficazes corrigidas ( $\left.\mu \mathrm{W} / \mathrm{cm}^{2}\right)$ e o erro (\%), efetuados com o radiômetro $\mathrm{R} 1$ e $\mathrm{R} 2$ a $25 \mathrm{~cm}$ da fonte $\mathrm{F} 2$, nos pontos 1 a 18 distribuídos na superfície efetiva descritos na FIG. 5.2 .

\begin{tabular}{|c|c|c|c|c|c|c|c|c|c|}
\hline $\mathrm{F} 2$ & Irradiância & $\begin{array}{l}\text { Irradiância } \\
\text { Espectral }\end{array}$ & Irradiância & \multicolumn{2}{|l|}{ Erro } & $\begin{array}{l}\text { Irradiância } \\
\text { Espectral }\end{array}$ & Irradiância & Erro & \\
\hline Ponto & $\begin{array}{c}E_{\mathrm{DIN}} \\
\left(\mu \mathrm{W} / \mathrm{cm}^{2}\right)\end{array}$ & $\begin{array}{c}\mathrm{R} 1 \\
\left(\mu \mathrm{W} / \mathrm{cm}^{2} \mathrm{~nm}\right)\end{array}$ & $\begin{array}{c}\mathrm{R} 1 \mathrm{C} \\
\mu \mathrm{W} / \mathrm{nm}\end{array}$ & $\left(\frac{R 1 C-E_{D I N}}{E_{D I N}}\right)$ & $\cdot 100$ & $\begin{array}{c}\mathrm{R} 2 \\
\left(\mu \mathrm{W} / \mathrm{cm}^{2} \mathrm{~nm}\right)\end{array}$ & $\begin{array}{c}\mathrm{R} 2 \mathrm{C} \\
\mu \mathrm{W} / \mathrm{nm}\end{array}$ & $\left(\frac{R 2 C-E_{D I N}}{E_{D I N}}\right)$ & $\cdot 100$ \\
\hline 1 & 926 & 7,1 & 686 & $-25,9$ & & 7,5 & 754 & $-18,6$ & \\
\hline 2 & 1177 & 10,8 & 1043 & $-11,4$ & & 11,7 & 1176 & $-0,1$ & \\
\hline 3 & 1471 & 13,0 & 1256 & $-14,6$ & & 13,2 & 1326 & $-9,8$ & \\
\hline 4 & 1457 & 12,9 & 1246 & $-14,5$ & & 13,7 & 1376 & $-5,5$ & \\
\hline 5 & 1093 & 11,5 & 1111 & 1,6 & & 11,4 & 1145 & 4,8 & \\
\hline 6 & 860 & 8,2 & 792 & $-7,9$ & & 7,1 & 713 & $-17,1$ & \\
\hline 7 & 879 & 8,0 & 773 & $-12,1$ & & 8,9 & 894 & 1,7 & \\
\hline 8 & 1298 & 12,8 & 1236 & $-4,8$ & & 13,0 & 1306 & 0,6 & \\
\hline 9 & 1505 & 15,2 & 1468 & $-2,5$ & & 15,1 & 1517 & 0,8 & \\
\hline 10 & 1497 & 15,5 & 1497 & 0,0 & & 14,9 & 1497 & 0,0 & \\
\hline 11 & 1288 & 13,6 & 1314 & 2,0 & & 12,4 & 1246 & $-3,3$ & \\
\hline 12 & 889 & 9,5 & 918 & 3,2 & & 7,7 & 774 & $-13,0$ & \\
\hline 13 & 975 & 7,5 & 724 & $-25,7$ & & 6,9 & 693 & $-28,9$ & \\
\hline 14 & 1166 & 10,9 & 1053 & $-9,7$ & & 10,3 & 1035 & $-11,2$ & \\
\hline 15 & 1273 & 12,8 & 1236 & $-2,9$ & & 12,2 & 1226 & $-3,7$ & \\
\hline 16 & 1244 & 13,1 & 1265 & 1,7 & & 11,5 & 1155 & $-7,1$ & \\
\hline 17 & 1098 & 11,3 & 1091 & $-0,6$ & & 9,5 & 954 & $-13,1$ & \\
\hline 18 & 772 & 7,9 & 763 & $-1,2$ & & 6,1 & 613 & $-20,6$ & \\
\hline
\end{tabular}


Tabela B3: Valores de irradiâncias $\left(\mu \mathrm{W} / \mathrm{cm}^{2}\right)$, irradiâncias espectrais eficazes $\left(\mu \mathrm{W} / \mathrm{cm}^{2} \mathrm{~nm}\right)$, irradiâncias eficazes corrigidas $\left(\mu \mathrm{W} / \mathrm{cm}^{2} \mathrm{~nm}\right)$, area do setor elíptico (cm $\left.{ }^{2}\right)$, potência espectral $(\mu \mathrm{W} / \mathrm{nm})$ e o erro (\%), efetuados com os radiômetros R1 e R2 a $45 \mathrm{~cm}$ da fonte H1, nos pontos 1 a 24 distribuídos na superfície efetiva descritos na FIG. 5.5.

\begin{tabular}{|c|c|c|c|c|c|c|c|c|c|c|c|}
\hline $\mathrm{H} 1$ & Irradiância & $\begin{array}{l}\text { Irradiância } \\
\text { Espectral }\end{array}$ & Irradiância & Área & $\begin{array}{l}\text { Potência } \\
\text { Espectral }\end{array}$ & Erro & & $\begin{array}{l}\text { Irradiância } \\
\text { Espectral }\end{array}$ & Irradiância & $\begin{array}{l}\text { Potência } \\
\text { Espectral }\end{array}$ & Erro \\
\hline Ponto & $\begin{array}{c}E_{\mathrm{DIN}} \\
\left(\mu \mathrm{W} / \mathrm{cm}^{2}\right)\end{array}$ & $\begin{array}{c}\mathrm{R} 1 \\
\left(\mu \mathrm{W} / \mathrm{cm}^{2} \mathrm{~nm}\right)\end{array}$ & $\begin{array}{c}\mathrm{R} 1 \mathrm{C} \\
\left(\mu \mathrm{W} / \mathrm{cm}^{2}\right)\end{array}$ & $\left(\begin{array}{c}A \\
\left(\mathrm{~cm}^{2}\right.\end{array}\right)$ & $\begin{array}{l}\mathrm{R} 1 \mathrm{C} \cdot \mathrm{A} \\
(\mu \mathrm{W} / \mathrm{nm})\end{array}$ & $\left(\frac{R 1 C-E_{D I N}}{E_{D I N}}\right)$ & $\cdot 100$ & $\begin{array}{c}\mathrm{R} 2 \\
\left(\mu \mathrm{W} / \mathrm{cm}^{2} \mathrm{~nm}\right)\end{array}$ & $\begin{array}{c}\mathrm{R} 2 \mathrm{C} \\
\left(\mu \mathrm{W} / \mathrm{cm}^{2}\right)\end{array}$ & $\begin{array}{c}\mathrm{R} 2 \mathrm{C} \cdot \mathrm{A} \\
\left(\mu \mathrm{W} / \mathrm{cm}^{2}\right)\end{array}$ & $\left(\frac{R 2 C-E_{D I N}}{E_{D I N}}\right) \cdot 100$ \\
\hline 1 & 779 & 5,5 & 673 & 12,1 & 8147 & $-13,5$ & & 3,3 & 1026 & 12417 & 31,8 \\
\hline 2 & 2696 & 18,2 & 2228 & 7,2 & 16042 & $-17,4$ & & 8,7 & 2705 & 19478 & 0,4 \\
\hline 3 & 3110 & 25,4 & 3110 & 2,4 & 7463 & 0,0 & & 10 & 3110 & 7463 & 0,0 \\
\hline 4 & 1070 & 8,1 & 992 & 2,4 & 2380 & $-7,3$ & & 3,7 & 1151 & 2761 & 7,6 \\
\hline 5 & 358 & 2,9 & 355 & 7,2 & 2556 & $-0,7$ & & 1,1 & 342 & 2463 & $-4,3$ \\
\hline 6 & 140 & 0,9 & 110 & 12,1 & 1333 & -21 & & 0,1 & 31 & 376 & $-77,7$ \\
\hline 7 & 420 & 3,2 & 392 & 13,6 & 5328 & $-6,8$ & & 2,4 & 746 & 10150 & 77,6 \\
\hline 8 & 1222 & 8,8 & 1077 & 6,0 & 6464 & $-11,8$ & & 5,4 & 1679 & 10075 & 37,4 \\
\hline 9 & 2374 & 17,3 & 2118 & 2,0 & 4236 & $-10,8$ & & 8,8 & 2736 & 5473 & 15,3 \\
\hline 10 & 1561 & 13,9 & 1702 & 2,0 & 3403 & 9,0 & & 4,6 & 1430 & 2861 & $-8,4$ \\
\hline 11 & 607 & 5,5 & 673 & 6,0 & 4040 & 11,0 & & 1,7 & 529 & 3172 & $-12,9$ \\
\hline 12 & 223 & 1,9 & 233 & 13,6 & 3164 & 4,4 & & 0,3 & 93 & 1269 & $-58,1$ \\
\hline 13 & 184 & 1,3 & 159 & 8,1 & 1289 & $-13,6$ & & 0,5 & 156 & 1259 & $-15,6$ \\
\hline 14 & 534 & 3,5 & 428 & 4,8 & 2057 & $-19,8$ & & 1,9 & 591 & 2836 & 10,6 \\
\hline 15 & 1430 & 11,4 & 1396 & 1,6 & 2233 & $-2,4$ & & 5,5 & 1710 & 2736 & 19,6 \\
\hline 16 & 2291 & 20,1 & 2461 & 1,6 & 3937 & 7,4 & & 7,3 & 2270 & 3632 & $-0,9$ \\
\hline 17 & 1245 & 14,4 & 1763 & 4,8 & 8462 & 41,6 & & 3,9 & 1213 & 5821 & $-2,6$ \\
\hline 18 & 574 & 5,2 & 637 & 8,1 & 5156 & 10,8 & & 1,5 & 466 & 3778 & $-18,8$ \\
\hline 19 & 135 & 0,8 & 98 & 10,1 & 989 & $-27,6$ & & 0,2 & 62 & 628 & $-54,0$ \\
\hline 20 & 355 & 2,7 & 330 & 6,0 & 1983 & $-6,9$ & & 1,1 & 342 & 2052 & $-3,7$ \\
\hline 21 & 1200 & 9,3 & 1139 & 2,0 & 2277 & $-5,1$ & & 4,9 & 1524 & 3047 & 27,0 \\
\hline 22 & 3000 & 24,2 & 2963 & 2,0 & 5925 & $-1,2$ & & 12 & 3732 & 7463 & 24,4 \\
\hline 23 & 2621 & 21,9 & 2681 & 6,0 & 16086 & 2,3 & & 11,7 & 3638 & 21829 & 38,8 \\
\hline 24 & 1044 & 9,8 & 1200 & 4,4 & 5279 & 15,0 & & 4,7 & 1462 & 6431 & 40,1 \\
\hline
\end{tabular}


Tabela B4: Valores de irradiâncias $\left(\mu \mathrm{W} / \mathrm{cm}^{2}\right)$, irradiâncias espectrais eficazes $\left(\mu \mathrm{W} / \mathrm{cm}^{2} \mathrm{~nm}\right)$, irradiâcias eficazes corrigidas $\left(\mu \mathrm{W} / \mathrm{cm}^{2} \mathrm{~nm}\right)$, area do setor elíptico $\left(\mathrm{cm}^{2}\right)$, potência espectral $(\mu \mathrm{W} / \mathrm{nm})$ e o erro (\%), efetuados com os radiômetros R1 e R2 a $45 \mathrm{~cm}$ da fonte H2, nos pontos 1 a 24 distribuídos na superfície efetiva descritos na FIG. 5.5 .

\begin{tabular}{|c|c|c|c|c|c|c|c|c|c|c|c|}
\hline $\mathrm{H} 2$ & Irradiância & $\begin{array}{c}\text { Irradiância } \\
\text { Espectral }\end{array}$ & Irradiância & Área & $\begin{array}{l}\text { Potência } \\
\text { Espectral }\end{array}$ & Erro & & $\begin{array}{c}\text { Irradiância } \\
\text { Espectral } \\
\end{array}$ & Irradiância & $\begin{array}{l}\text { Potência } \\
\text { Espectral }\end{array}$ & Erro \\
\hline Ponto & $\begin{array}{c}E_{\mathrm{DIN}} \\
\left(\mu \mathrm{W} / \mathrm{cm}^{2}\right)\end{array}$ & $\begin{array}{c}\mathrm{R} 1 \\
\left(\mu \mathrm{W} / \mathrm{cm}^{2} \mathrm{~nm}\right)\end{array}$ & $\begin{array}{c}\mathrm{R} 1 \mathrm{C} \\
\left(\mu \mathrm{W} / \mathrm{cm}^{2}\right)\end{array}$ & $\begin{array}{c}\hat{A} \\
\left(\mathrm{~cm}^{2}\right)\end{array}$ & $\begin{array}{c}\mathrm{R} 1 \mathrm{C} \cdot \mathrm{A} \\
(\mu \mathrm{W} / \mathrm{nm})\end{array}$ & $\left(\frac{R 1 C-E_{D I N}}{E_{D I N}}\right.$ & $\cdot 100$ & $\begin{array}{c}\mathrm{R} 2 \\
\left(\mu \mathrm{W} / \mathrm{cm}^{2} \mathrm{~nm}\right)\end{array}$ & $\begin{array}{c}\mathrm{R} 2 \mathrm{C} \\
\left(\mu \mathrm{W} / \mathrm{cm}^{2}\right)\end{array}$ & $\begin{array}{c}\mathrm{R} 2 \mathrm{C} \cdot \mathrm{A} \\
(\mu \mathrm{W} / \mathrm{nm})\end{array}$ & $\left(\frac{R 2 C-E_{D I N}}{E_{D I N}}\right) \cdot 100$ \\
\hline 1 & 610 & 3,3 & 406 & 17,3 & 7025 & $-33,4$ & & 4,1 & 1299 & 22474 & 113,1 \\
\hline 2 & 15467 & 11,2 & 1378 & 10,1 & 13919 & $-10,9$ & & 6,4 & 2028 & 20481 & 31,1 \\
\hline 3 & 1267 & 10,3 & 1267 & 3,4 & 4309 & 0,0 & & 4,0 & 1267 & 4309 & 0,0 \\
\hline 4 & 941 & 7,2 & 886 & 3,4 & 3012 & $-5,8$ & & 2,1 & 665 & 2262 & $-29,3$ \\
\hline 5 & 342 & 3,5 & 431 & 10,1 & 4350 & 26,1 & & 0,8 & 254 & 2560 & $-25,8$ \\
\hline 6 & 116 & 1,0 & 123 & 17,3 & 2129 & 6,5 & & 0,0 & 0,0 & 0 & -100 \\
\hline 7 & 473 & 1,7 & 209 & 20,0 & 4184 & $-55,7$ & & 1,2 & 380 & 7604 & $-19,5$ \\
\hline 8 & 1385 & 7,4 & 911 & 8,1 & 7376 & $-34,3$ & & 3,9 & 1236 & 10009 & $-10,8$ \\
\hline 9 & 1300 & 9,2 & 1132 & 2,7 & 3056 & $-12,9$ & & 3,7 & 1172 & 3165 & $-9,8$ \\
\hline 10 & 1090 & 8,0 & 984 & 2,7 & 2658 & $-9,7$ & & 2,6 & 824 & 2224 & $-24,4$ \\
\hline 11 & 499 & 5,2 & 640 & 8,1 & 5183 & 28,2 & & 0,9 & 285 & 2309 & $-42,9$ \\
\hline 12 & 172 & 1,7 & 209 & 20,0 & 4184 & 21,5 & & 0,1 & 32 & 634 & $-81,6$ \\
\hline 13 & 226 & 1,3 & 160 & 9,8 & 1568 & $-29,2$ & & 0,4 & 127 & 1242 & $-43,9$ \\
\hline 14 & 794 & 5,5 & 677 & 6,1 & 4128 & $-14,7$ & & 1,9 & 602 & 3672 & $-24,2$ \\
\hline 15 & 1223 & 8,6 & 1058 & 2,0 & 2116 & $-13,5$ & & 3,2 & 1014 & 2028 & $-17,1$ \\
\hline 16 & 1207 & 8,2 & 1009 & 2,0 & 2018 & $-16,4$ & & 3,3 & 1046 & 2091 & $-13,4$ \\
\hline 17 & 848 & 7,1 & 874 & 6,1 & 5329 & 3,0 & & 2,2 & 697 & 4252 & $-17,8$ \\
\hline 18 & 332 & 2,1 & 258 & 9,8 & 2532 & $-22,1$ & & 0,5 & 158 & 1553 & $-52,2$ \\
\hline 19 & 148 & 1,3 & 160 & 13,5 & 2160 & 8,4 & & 0,1 & 32 & 428 & $-78,5$ \\
\hline 20 & 518 & 4,0 & 492 & 8,1 & 3987 & $-5,0$ & & 0,7 & 222 & 1797 & $-57,2$ \\
\hline 21 & 1000 & 7,2 & 886 & 2,7 & 2392 & $-11,4$ & & 2,8 & 887 & 2395 & $-11,3$ \\
\hline 22 & 1298 & 8,6 & 1058 & 2,7 & 2857 & $-18,4$ & & 3,8 & 1204 & 3251 & $-7,2$ \\
\hline 23 & 1045 & 8,7 & 1070 & 8,1 & 8671 & 2,4 & & 4,4 & 1394 & 11292 & 33,4 \\
\hline 24 & 356 & 3,4 & 418 & 13,5 & 5648 & 17,6 & & 2,0 & 634 & 8555 & 78,2 \\
\hline
\end{tabular}




\section{REFERÊNCIAS BIBLIOGRÁFICAS}

1 AMERICAN ACADEMY OF PEDIATRICS. Subcommittee on hyperbilirubinemia, anonymous; management of hyperbilirubinemia in the new born infant 35 or more weeks of gestation. Pediatrics, v.114, p.297316, 2004.

2 ASSOCIAÇÃO BRASILEIRA DE NORMAS TÉCNICAS - ABNT. NBR-IEC 60601-2-50: equipamento eletromédico, parte 2-50: prescrições particulares para segurança de equipamento de fototerapia. Rio de Janeiro: ABNT, 2003.

3 BABIN, J.P.; LACHAUX, V.de; SENDER A.G. La photothérapie intensive de l'ictère néonatal. Arch. Fr. Pédiatr., v.48, p.433-436, 1991.

4 BALLOWITZ, L. et al. Photherapy in gun rats. Biol. Neonate, v.31, p.229244, 1977.

5 BONTA, B. W.; WARSHAW, J.B. Importance of radiant flux in the treatment of hyperbilirubinemia: failure of overhead phototerapy units in intensive care units. Pediatrics, v.57, n.4, p.502-505, 1976.

6 CALDERA, R.; SENDER, A. Indications et technique de la photothérapie intensive chez le nouveau-né à terme. Arch. Pédiatr., v.4, p.803-804, 1997.

7 CORDERO, R.R.; SECKMEYER, G.; LABBE, F. Cosine error influence on ground-based spectral UV irradiance measurements. Metrologia, v.45, p.406-414, 2008.

8 COSTARINO, A.T.; ENNEVER J. F.; BAUMGART S. Bilirrubin photoisomerization in premature nenonates under low and high dose phottherapy. Pediatrics, v.75, p.519-522, 1985.

9 CREMER, R.; PERRYMAN, P.; RICHARDS, D. H.; Influence of litghg on the hyperbilirrubinemia of infants. Lancet , v.1, p.1094-1097, 1958.

10 DE CARVALHO, M. Recentes avanços em fototerapia. In: SIMPÓSIO INTERNACIONAL DE NEONATOLOGIA, 1., 1999, Rio de Janeiro. Anais...

11 DE CARVALHO, M.; LOPES, J.M.; NETTO, D.B. Fototerapia integral de alta intensidade para o tratamento da ictirícia do recém-nascido. Revista Brasileira de Engenharia Biomédica, v.15, n.3, p.109-113, set./dez., 1999.

12 DEUTSCHES INSTITUT FÜR NORMUNG - DIN. DIN 5031 -10:

Strahlungsphysik im optischen Beereich und Lichttechnik. Berlin, 2000.

13 DICKEN, P.; GRANT, L.J.; JONES, S. An evaluation of the characteristics and performance of neonatal phototherapy equipment. Physiol. Meas., v. 21, p. $493-503,2000$. 
14 EBBESEN, F. et al. Therepeutic effect of turquouse versus blue light with equal irradiance in peterm infants with jaundice. Acta Pediatrica, v.96, p.837-841, 2007.

15 ENNEVER, J.F.; SOBEL, M.; MCDONAGH, A. F. Phototherapy for neonatal jaundice: in vitro, comparison of lights sources. Pediatric Research, v.18, p. 667-669, 1984.

16 ENVALL, J.; KARHA, P. Calibration of broadband ultraviolet detectors by measurement of spectral irradiance responsivity. Review of Scientific Instruments, v.77, p.063110-1- 063110-8, 2006.

17 FACHINI, F.P. Proposta de padronização para aferição de equipamentos de fototerapia. Jornal de Pediatria, v.77, n.2, 2001.

18 FERREIRA, H.C. BEREZIN, D.; LARRUBIA, M.N. A Super-iluminação na hiperbilirrubinemia do recém-nascido a termo. Jornal de Pediatria, v.57, p.335-338, 1960.

19 HAMMERMAN, C. et al. Comparative measurements of phototherapy: apractical guide. Pediatrics, v.67,p.368-72, 1981.

20 HANSEN, T.W.R. Phototherapy for neonatal jaundice - still in need of fine tuning. Acta Pediatr., v.89, p.770-772, 2000.

21 INTERNNATIONAL ELECTROTECHNICAL COMMISSION - IEC. IEC60601-2-50: medical electrical equipment; part 2-50: particular requirements for the safety of infant phototherapy equipment. Geneva, 2000.

22 KLIEMANN, R.; NOHAMA,P. Avaliação dos equipamentos de fototerapia no tratamento da hiperbilirrubinemia neonatal em maternidade de Curitiba (Brasil). In: CONGRESSO LATINO AMERICANO DE INGENIERIA BIOMÉDICA, 2., 2001, Haban, Cuba. Mayo 23 al 25, La Haban, Cuba, 2001

23 LIGTHNER, D.A.; LINNANE, W.P.III; AHFORS, C.E. Bilirubin photooxidation products in the urine of jandiced infants receiving phototherapy. Pediatric Research, v.18, p.696-700, 1984.

24 KLEIN, R.M. Shedding light on the use of light. Pediatrics, v.50, n.1, p.118126, 1972.

25 LUCEY, J.F.; FERREIRO, M.; HEWITT, J. Prevention of hyperbilirbinemia of premtury by phototherapy. Pediatrics, v.41, n.6, p.1047-1054, jun., 1968.

26 LUCEY, J.F. Light: a time for change to "radiant flux," or microwatts per square centimeter $\left(\mu \mathrm{W} / \mathrm{cm}^{2}\right)$. Pediatrics, v.50, n.5, 1972.

27 MCDONAGH, A.F.; LIGHTNER, D.A. "Like a shriveled blood orange": bilirubin, jaundice and phototherapy. Pediatrics, v.75, n.3, p.443-455, 1985.

28 MACLEOD, P.; STERN, L. Natural variation in environmental illumination in a newborn nursery. Pediatrics, v.50, n.1, jul., 1972. 
29 MAISELS, M.J. Jaundice. In: AVERY, G.B.; FLETCHER, M.A.; MAC DONALD, M.G. (eds.) Neonatology: pathophysiology and management of the newborn. 4.ed. Philadelphia: J.B. Lippincott Company, 1994. Cap.38, p.630.

30 MAISELS, J.M. Neonatal jaundice. In: AVERY, G.B.(ed.) Neonatology. 2.ed. Philadelphia: J.B. Lippinicot, 1981.

31 MAISELS, M.J. Phototherapy: tradicional and nontradicional. Journal of Perinatology, v.21, p.S93-S97, 2001.

32 MAISELS, J.M. Why use homeopathic doses of phototherapy? Pediatrics, v.98, n.2, p.283-287, 1996.

33 MAISELS, M.J., WATCHKO, J.F. Treatment of jaundice in low birthweight infants. Arch. Dis. Child. Fetal Neonatal Ed., v.88, p.F459-F463, 2003.

34 MIGLIORINI M. G.; GALVAN P.; SBRANA G.; DONZELLI G.P.; VECCHI C. Bililrubin photoconversion induced by monochromatic laser radiation; comparison between aerobic and anaerobic experiments in vitro. Biochem. J., v.256, p.841-846, 1988.

35 MIMS L. C.; ESTRADA M.; GOODEN D. S.; CADWELL R. R.; KOTAS R. V. Phototherapy for neonatal hyperbilirubinaemia: a dose response relationship. Fetal and Neonatal Medicine, v.83, p.658-662, 1973.

36 MODI, N.; KEAY A.J. Phototherapy for neonatal hyperbilirubinaemia: the importance of dose. Arch. Dis. Child., v.58, p.406-409, 1983.

37 SBRANA, G.; DONZELLI, G.P.; VECCHI, C. Phototherapy in the management of neonatal hyperbilirubinaemia: efficacy with light sources emintting more than 500 nanometers. Pediatrics, v.80, p.395-399, 1987.

38 SISSON T, R.C. Photherapy of jaundice in the newborn infant II. Effect of various light intensities. J.Pediatr., v.81, p.35-38, 1972.

39 SLINEY, D.H. Radiometric quantities and units used in photobiology and photochemistry: recommendations of the Commission Internationale de l'Eclairage (International Commission on Illumination). Photochemistry and Photobiology, v.83, p.425-432, 2007.

40 TAN, K. L. The nature of the dose response relationship of phottherapy for neonatal hyperbilirubinaemia. J. Pediatr., v.90, p.448-52, 1977.

41 TAN, K. L. The pattern of bilirubin response to photherapy for neonatal hyperbilirubinaemia. Pediatric Research, v.16, p.670-674, 1982. 
42 TAN, K.L. Phototherapy for neonatal jaundice. Clinical in Perinatology, v.18, n.3, p.423-439, 1992.

43 TAN, K.L. Efficacy of bidirectional fiber-optic phototherapy for neonatal hyperbilirubinemia. Pediatrics, v.99, n.13, 1997.

44 VREMAN H.J.; WONG R.J.; STEVENSON D.K.; ROUTE R.K.; READER S.D.; FEJER M.M.; GALE F.; SEIDMAN D.S., Light emitting diodes: a novel light source for phototherapy. Pediatric Research, v.44, n.5, p.804-809, 1998.

45 VREMAN H, J.; WONG, J.; STEVENSON, D.K. Phototherapy: current methods and future directions. Semin. Perinatol., v.28, p.326-33, 2004.

$46 \mathrm{XU}$, G.; HUANG, X.; LIU, Y. Area correction in the calibration of detectorsfor ultraviolet radiation measurement. Metrologia, v.37, p.556-559, 2000.

47 XU, G.; HUANG, X. Calibration of broadband UV radiometersmethodology and uncertainty evaluation. Metrologia, v.40, p.S21-S24, 2003.

48 WIESE, G.; BALLOWITZ, L. A mathematical description of the temporal chnges in serum bilirubin concentration during phototherapy in newborn infants. Biology of Neonate, v.42, p.222-225, s.d.

49 YARIV, A. On transmission and recovery of three-dimensional image information in optical waveguides. J. Opt. Soc. Am., v.66, n.4, apr., 1976. 